\title{
Economic sustainability of food supply chains: Life cycle costs and value added in the confectionary and frozen desserts sectors
}

DOI:

10.1016/j.scitotenv.2019.03.274

\section{Document Version}

Accepted author manuscript

Link to publication record in Manchester Research Explorer

Citation for published version (APA):

Konstantas, A., Stamford, L., \& Azapagic, A. (2019). Economic sustainability of food supply chains: Life cycle costs and value added in the confectionary and frozen desserts sectors. Science of the Total Environment.

https://doi.org/10.1016/j.scitotenv.2019.03.274

Published in:

Science of the Total Environment

\section{Citing this paper}

Please note that where the full-text provided on Manchester Research Explorer is the Author Accepted Manuscript or Proof version this may differ from the final Published version. If citing, it is advised that you check and use the publisher's definitive version.

\section{General rights}

Copyright and moral rights for the publications made accessible in the Research Explorer are retained by the authors and/or other copyright owners and it is a condition of accessing publications that users recognise and abide by the legal requirements associated with these rights.

\section{Takedown policy}

If you believe that this document breaches copyright please refer to the University of Manchester's Takedown Procedures [http://man.ac.uk/04Y6Bo] or contact uml.scholarlycommunications@manchester.ac.uk providing relevant details, so we can investigate your claim.

\section{OPEN ACCESS}


Science of the Total Environment, https://doi.org/10.1016/j.scitotenv.2019.03.274

\title{
Economic sustainability of food supply chains: life cycle costs and value added in the confectionary and frozen desserts sectors
}

\author{
Antonios Konstantas, Laurence Stamford and Adisa Azapagic* \\ Sustainable Industrial Systems, School of Chemical Engineering and Analytical Science, The \\ University of Manchester, The Mill, Sackville Street, Manchester M13 9PL, UK
}

*Corresponding author: adisa.azapagic@manchester.ac.uk

\begin{abstract}
The confectionary and frozen desserts sectors are important parts of the food industry but have received relatively little attention from a life cycle cost perspective. Thus, the purpose of the current study is to evaluate the life cycle costs (LCC) and value added (VA) in these sectors in the UK, focusing on four major product categories: biscuits, cakes (ambient and frozen), chocolates and ice cream. In total, 18 products are considered along their life cycles, including the raw materials, manufacturing, packaging, distribution, retail, consumption and waste management stages. The results suggest that cakes have the highest LCC (£1.52$2.64 / \mathrm{kg})$ and the biscuits the lowest $(£ 0.72-0.91 / \mathrm{kg})$. The LCC of chocolates and ice cream fall within a similar range (£1.16-1.46/kg and £1.03-1.30/kg, respectively). Divergent trends are noted between LCC and VA: for instance, 'premium' ice creams have only $18 \%$ higher costs than their 'regular' counterparts, but a four-fold higher VA. For all the products, raw materials contribute most to the costs $(43 \%-95 \%)$, followed by packaging $(1 \%-29 \%)$ and manufacturing (1\%-14\%). The annual LCC at the sectoral level are estimated at $£ 3.455$ billion, to which biscuits contribute $42 \%$. The share of chocolates and cakes is $24 \%$ and $19 \%$, respectively, with ice cream contributing the remaining 15\%. By contrast, chocolates contribute more than $50 \%$ of the total sectoral VA, which is five-fold higher than that of ice cream. The study also demonstrates how LCC can be used to evaluate the eco-efficiency of products and sectors. With respect to global warming potential, whole cakes are the most eco-efficient and vanilla regular ice cream the least efficient products. Overall, the confectionary sector is nearly $60 \%$ more eco-efficient than the frozen desserts sector. These results can be used for benchmarking and to drive innovation towards more economicallysustainable and eco-efficient confectionary and frozen desserts supply chains.
\end{abstract}

Keywords: Biscuits; Cakes; Chocolates; Ice cream; Economic assessment; Eco-efficiency.

\begin{tabular}{|ll|}
\hline \multicolumn{2}{|l|}{ Nomenclature } \\
$C_{C L(C O)}$ & cost of washing the dishes at consumer \\
$C_{C O}$ & costs associated with product consumption \\
$C_{D C}$ & costs of operating distribution centre \\
$C_{E O L}$ & costs of post-consumer waste management \\
$C_{M A}$ & costs of product manufacturing \\
$C_{P A(C O)}$ & cost of consumer shopping bag \\
$C_{P A}$ & costs of packaging \\
$C_{R E}$ & costs associated with the retail \\
$C_{R M}$ & costs of raw materials (ingredients) \\
$C_{S T(C O)}$ & cost of refrigerated storage at consumer \\
$C_{T R(C t G)}$ & transport costs from cradle to grave \\
$C_{T R(C T M A)}$ & transport costs from cradle to manufacturer \\
$C_{T R(M A t R E)}$ & transport costs from manufacturer to retailer \\
$C_{T R(R E t C O)}$ & transport costs from retailer to consumer's home \\
$L C C_{C t G}$ & total life cycle costs of a product from cradle to grave \\
$L C C_{M A}$ & manufacturer's life cycle costs \\
$L C C C_{R E}$ & retailer's life cycle costs \\
$P$ & product selling price \\
$S$ & savings (system credits) related to end-of-life waste management \\
$V A$ & value added \\
\hline
\end{tabular}




\section{Introduction}

The food sector is an important part of the global economy and a significant contributor to costs of living. In developing countries, it accounts for $38.6 \%$ of household expenditure (World Bank, 2010). In developed countries, this share is lower but still substantial. For example, in Japan, $23 \%$ of household income is spent on food, in the US $14 \%$ and in the UK $11 \%$ (FAO, 2015). However, despite its importance, relatively little work exists within the scientific literature related to the life cycle economic sustainability in the food sector. Only a handful of studies have assessed the costs of food products or specific sub-sectors across their entire life cycle. For instance, Schmidt Rivera \& Azapagic (2014) analysed the life cycle costs (LCC) of chilled and frozen ready-made meals in comparison with their home-made equivalents. Other studies include that by Settani et al. (2010) who considered the LCC of pasta and by Nguyen et al. (2012) who evaluated the cost of environmental impacts of meat production. Furthermore, Sonye-Mengual et al. (2018) reported the LCC of fresh vegetables at the consumption point. A similar approach was also adopted by Laso et al. (2018) in the evaluation of fresh anchovies.

Aside from the above studies, no other life cycle costing work related to food products is available in the literature. Specifically, there is a notable lack of studies of confectionary, ice cream and other frozen desserts, despite the omnipresence and popularity of these products worldwide. The current study seeks to fill this research gap by estimating LCC and value added (VA) of the production and consumption of confectionary and frozen desserts. The study is based in the UK, which is the second highest consumer of these products in Europe after Germany (Statista, 2018a; 2018b). Four major product categories are considered within these two sectors - biscuits, chocolates, cakes (ambient and frozen) and ice cream focusing on the leading products identified through a market analysis. In addition to LCC and VA, their eco-efficiency is also considered based on their life cycle global warming potential and the LCC. The analysis is carried out at the product and sectoral levels and is aimed at manufacturers and consumers. This is detailed in the next section, together with the methods used in the study. Although the study focuses on UK market conditions, the methods described below are generic and can be applied to estimating the LCC and VA of these sectors in other countries.

\section{Methods}

The methodology applied in this work comprises the following steps:

1. market analysis of the confectionary and frozen desserts sectors to select market-leading products to be considered;

2. LCC, VA and eco-efficiency estimation at the product and sectoral levels; and

3. sensitivity and uncertainty analysis to ensure the robustness of the results.

These are described in turn below.

\subsection{Market analysis and selection of products}

The confectionary and frozen desserts sectors are very diverse and can be divided in many different sub-sectors and product categories. In this work, the focus is on the aforementioned four major product categories consumed widely worldwide, including in the UK. Each product category is also very diverse and considering the whole range of products is not feasible. Therefore, to focus the study, a market analysis has been carried out to identify and select products with the highest market share. These are listed in Table 1, which also shows the annual sales by value of the four product categories selected for consideration.

As indicated in Table 1, the annual UK sales of biscuits amount to $£ 2.608$ billion (Key Note 2015a), with a total volume sold estimated in this study at $1.7 \mathrm{Mt} / \mathrm{yr}$; for the estimates, see Table S1a in the Supplementary Information (SI). Fig. 1a shows that the greatest market share by volume is occupied by low fat \& sugar biscuits $(23.5 \%)$, followed by crackers $(13.9 \%)$, semi-sweet $(10.8 \%)$ and chocolate cream biscuits $(10.8 \%)$. Therefore, these have been selected for consideration in this study. In addition, vanilla cream sandwich and chocolate-coated biscuits are also considered ( $8 \%$ each). The remaining $25.1 \%$ of the sales 
volume are other biscuits involving a great variety of products with small individual contributions (Key Note 2015a). Hence, they are not considered at the product level but are included in the assessment at the sectoral level.

The cakes sector is worth $£ 1.646$ billion per year, of which ambient storage cakes are valued at $£ 1.37$ billion (Key Note, 2015a) and frozen cakes at £0.272 billion (Key Note, 2015c). An estimated total $360 \mathrm{Mt}$ of cakes are consumed annually in the UK (Table S1b in the SI). As indicated in Fig. $1 \mathrm{~b}$, the leading product types by volume are apple pies $(50.4 \%)$, cheesecake $(17.6 \%)$; cake slices (12.6\%), whole cakes (11.7\%) and cupcakes $(7.7 \%)$. Therefore, these have been chosen for evaluation, assuming that apple pies represent all pies and Victoria sponge all cakes. Strawberry cheesecake is presumed representative of all other types of cheesecake while vanilla flavoured cake slices with sugar icing represent all types of cake slice.

Table 1 Market-leading products in the biscuits, cakes, chocolates and ice creams sectors.

\begin{tabular}{|c|c|c|c|}
\hline $\begin{array}{l}\text { Biscuits } \\
\left(^{(£ 2.608 \text { billion/yr) }}{ }^{a}\right.\end{array}$ & $\begin{array}{l}\text { Cakes } \\
\text { (£1.646 billion/yr) }^{\mathrm{a}}\end{array}$ & $\begin{array}{l}\text { Chocolates } \\
\text { (£4.344 billion/yr) }^{\text {a }}\end{array}$ & $\begin{array}{l}\text { Ice cream } \\
(£ 1.133 \text { billion/yr) }\end{array}$ \\
\hline Crackers & Whole cakes & Moulded chocolate & Vanilla regular \\
\hline Low fat/low sugar & Cake slices & Chocolate countlines & Vanilla premium \\
\hline Semi-sweet & Pies & Chocolates in bags & Chocolate regular \\
\hline Chocolate-coated & Cupcakes & & Chocolate premium \\
\hline Chocolate cream & Cheesecake & & \\
\hline Vanilla cream & & & \\
\hline
\end{tabular}

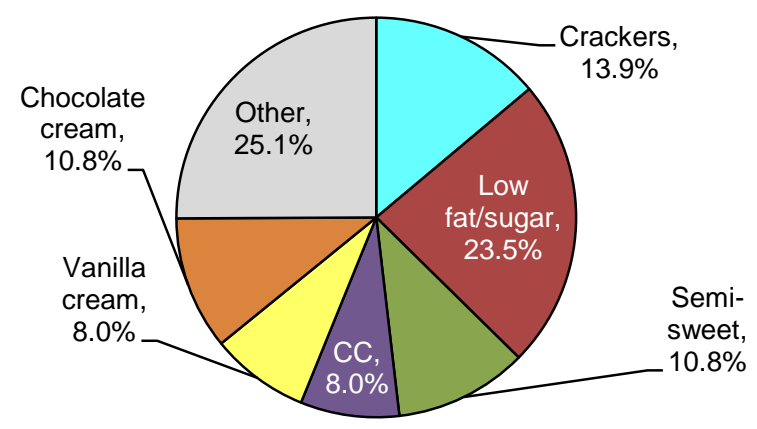

a) Biscuits

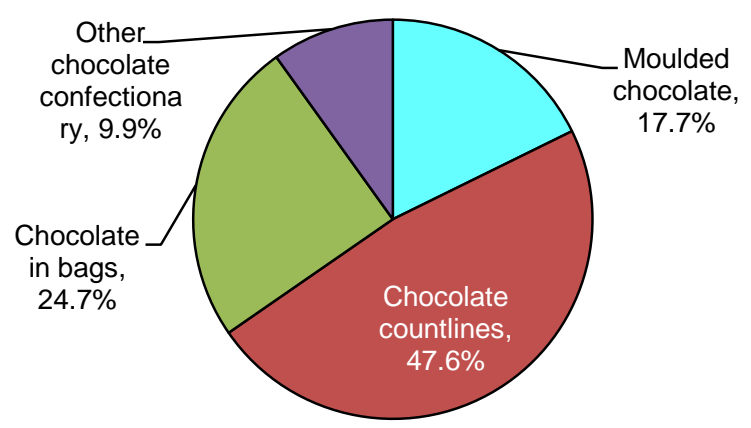

c) Chocolates

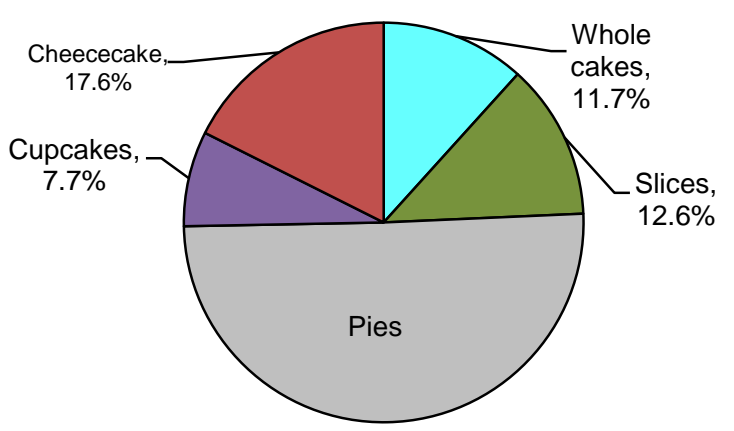

b) Cakes

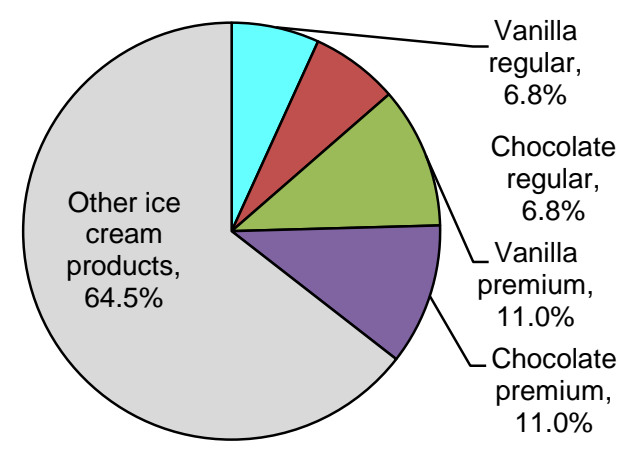

d) Ice cream

Fig. 1 Market share by volume of leading products in the biscuits, cakes, chocolates and ice cream sectors [Estimates based on data for annual share of different products by value sourced from the literature as follows: Biscuits \& cakes: Key Note (2015a); Chocolates: Key Note (2015b); Frozen desserts (including ice cream): Key Note (2015c). For details, see Table S1 in the SI. CC: Chocolate-coated biscuits]. 
The chocolates sector is the market leader by value among the four sectors considered, with an estimated £4.344 billion/yr (Key Note, 2015b). As indicated in Fig. 1c, the leading products by volume are chocolate countlines (47.6\%), chocolates in bags (24.7\%), moulded chocolates (17.7\%) and other chocolate confectionaries (9.9\%) (Konstantas et al., 2018). For these estimates, see Table S1C in the SI. Hence, these products have been selected for further consideration.

Finally, the ice cream market has annual sales of $£ 1.133$ billion (Key Note, 2015c). Vanilla and chocolate ice cream are the leading flavours, occupying nearly $36 \%$ of the total market volume, with around $18 \%$ each (see Fig. 1d and Table S1d). The other ice cream products are wrapped 'impulse' ice cream and multipacks (Key Note, 2015c). The latter refers to individual wrapped impulse products sold together.

\subsection{Life cycle costing, value added and eco-efficiency}

The methodology for life cycle costing adopted in this study is that based on Hunkeler at al. (2008). The value-added and eco-efficiency estimates are based on LCC as described in more detail further below. Prior to that, the next section gives an overview of the goal and scope of the study.

\subsubsection{Goal and scope of the study}

The goals of the study are:

i. to estimate total LCC and VA in the life cycle of biscuits, cakes, chocolate and ice cream at the product level, based on a basket of 18 individual market-leading products (Table $1)$;

ii. to estimate costs of these products to different stakeholders: manufacturers, retailers and consumers;

iii. to identify the economic hotspots in the life cycles of these products;

iv. to evaluate the annual LCC and VA at the sectoral level based on the annual consumption of confectionary products and frozen desserts in the UK; and

v. to determine the eco-efficiency at the product and sectoral levels.

To achieve these goals, two functional units are defined, as follows:

- $1 \mathrm{~kg}$ of product consumed at home (study goals i-iii); and

- annual consumption of each product in the UK (study goal iv).

The system boundary spans cradle to grave, comprising production of raw materials and products, their packaging, distribution, retail, consumption, end-of-life waste management and all life cycle transport steps. This is depicted in Fig. 2, which also shows the system boundaries used to estimate the costs to manufacturers, retailers and consumers.

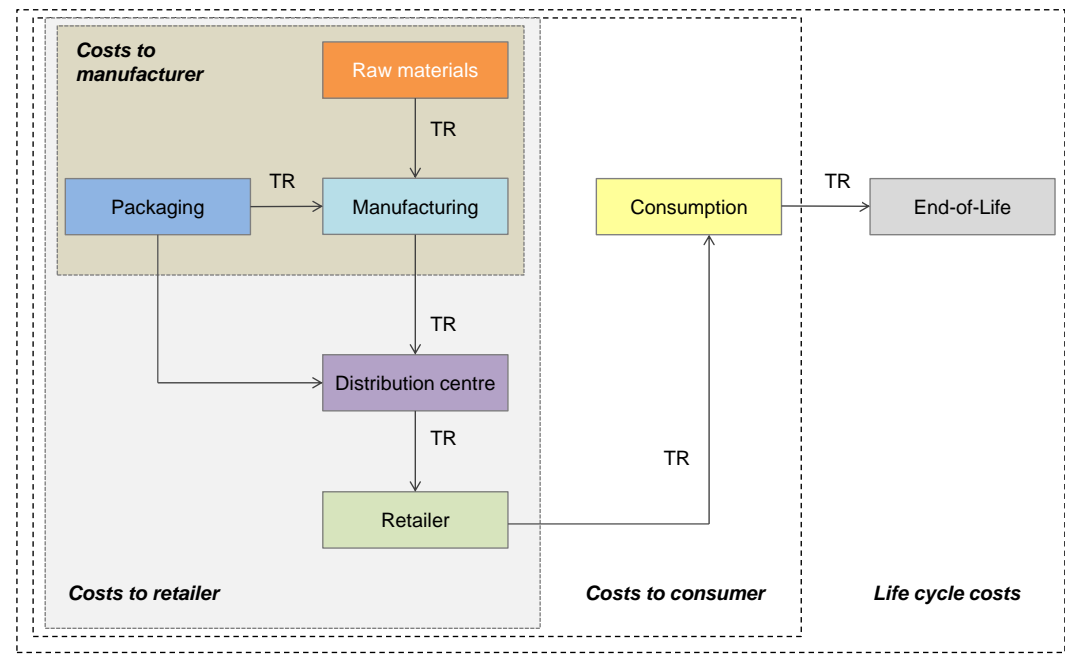

Fig. 2 Life cycle stages considered for life cycle costing and the system boundaries for the costs to manufacturers, retailers and consumers [TR: transport]. 


\subsubsection{Estimation of life cycle costs and value added}

The total life cycle costs of individual products have been calculated as follows:

$$
L C C_{C t G}=C_{R M}+C_{M A}+C_{P A}+C_{D C}+C_{R E}+C_{C O}+C_{E O L}+C_{T R(C t G)}-S
$$

where:

$L C C_{C t G}$ : total life cycle costs of a product from cradle to grave

$C_{R M}$ : $\quad$ costs of raw materials (ingredients)

$C_{M A}: \quad$ costs of product manufacturing

$C_{P A}: \quad$ costs of packaging

$C_{D C}: \quad$ costs of operating distribution centre

$C_{R E}: \quad$ costs associated with the retail

$C_{C O}$ : costs associated with product consumption

$C_{E O L}: \quad$ costs of post-consumer waste management

$C_{T R(C t G):}$ transport costs from cradle to grave

$S$ : $\quad$ savings (system credits) related to end-of-life waste management (recycling and energy recovery).

Considering costs to different stakeholders, the manufacturer's life cycle costs comprise costs of raw materials, manufacturing, packaging and all transport up to the manufacturing facility, as illustrated in Fig. 2 and defined by eqn. (2):

$$
L C C_{M A}=C_{R M}+C_{M A}+C_{P A}+C_{T R(C t M A)}
$$

where:

$L C C_{M A}:$ manufacturer's life cycle costs

$C_{T R(C t M A)}$ : transport costs from cradle to manufacturer.

Costs to the retailer incorporate the manufacturer's costs, costs of operating distribution centres and retail space as well as transport costs from the manufacturing gate to the retailer (Fig. 2):

$$
L C C_{R E}=C_{M A}+C_{D C}+C_{R E}+C_{T R(M A t R E)}
$$

where:

$L C C_{R E}:$ retailer's life cycle costs

$C_{T R \text { (MAtRE): }}$ transport costs from manufacturer to retailer.

Finally, from the consumer's perspective, life cycle costs include the retailer's costs, costs of transport to purchase the product and a (plastic) shopping bag, as well as the cost of electricity for refrigerated storage and energy and water for cleaning the dishes:

$$
L C C_{C O}=C_{R E}+C_{T R(R E t C O)}+C_{P A(C O)}+C_{S T(C O)}+C_{C L(C O)}
$$

where:

$C_{\text {TR(REtCO): }}$ transport costs from retailer to consumer's home

$C_{P A(C O)}:$ cost of consumer shopping bag (allocated to the functional unit on volume basis)

$C_{S T(C O)}: \quad$ cost of refrigerated storage at consumer (ice cream and frozen cakes)

$C_{C L(C O)}$ : cost of cleaning the dishes.

In addition to LCC, VA has also been estimated at both the product and sectoral levels. VA is defined as the sales price minus the costs of goods sold (Sutherland \& Canwell, 2004), reflecting the increase in economic value due to the production of the final goods. Therefore, the VA is calculated considering the life cycle costs incurred up to the retail point where the product is sold, as follows:

where:

$$
V A=P-L C C_{R E}
$$

$V A$ : value added 
$P$ : $\quad$ product selling price.

\subsubsection{Estimation of eco-efficiency}

Following the definition by the World Business Council for Sustainable Development (Lehni, 2000), the eco-efficiency can be estimated as a ratio of an environmental impact to the economic value of a product or service. LCC can be used as an indicator of a product system value (ISO, 2012) as any cost variation alters the economic value added and consequently the corresponding system value. Different environmental impacts can be considered for the estimation of eco-efficiency. Here, global warming potential is selected as one of the key impacts of interest to manufacturers, policy makers and consumers. Therefore, the ecoefficiency is estimated as a ratio of GWP and LCC, both at the product and sectoral levels, with the lower values representing a higher efficiency. The GWP values for the products and sectors have been sourced from Konstantas (2018), Konstantas et al. (2018) and Konstantas et al. (2019). These have been estimated based on the same system boundary as for the LCC and are summarised in Table 2 and Table 3, respectively.

Table 2 Global warming potential (GWP) of confectionary products and frozen desserts (Konstantas, 2018, Konstantas et al., 2018, Konstantas et al., 2019)

\begin{tabular}{ll}
\hline Product & $\begin{array}{l}\text { GWP } \\
\text { (kg CO } \mathbf{~ e q . / k g ) ~}\end{array}$ \\
\hline Biscuits & \\
Crackers & 1.31 \\
Low fat/sugar & 1.27 \\
Semi-sweet & 1.28 \\
Chocolate coated & 1.81 \\
Vanilla cream & 1.29 \\
Chocolate cream & 1.36 \\
Cakes & \\
Whole cakes & 2.04 \\
Cake slices & 1.78 \\
Pies & 1.58 \\
Cupcakes & 2.18 \\
Cheesecakes & 4.83 \\
Chocolates & \\
Moulded chocolate & 3.39 \\
Chocolate countlines & 2.91 \\
Chocolates in bags & 4.15 \\
Ice cream & \\
Vanilla regular & 3.75 \\
Chocolate regular & 3.66 \\
Vanilla premium & 3.94 \\
Chocolate premium & 3.91 \\
\hline
\end{tabular}

Table 3 Global warming potential (GWP) of the confectionaries and frozen sectors based on the annual consumption in the UK (Konstantas, 2018)

\begin{tabular}{ll}
\hline Sub-sectors and sectors & $\mathbf{G W P}\left(\mathbf{k t} \mathbf{C O}_{\mathbf{2}}\right.$ eq./yr) \\
\hline Biscuits sub-sector & 2573 \\
Cakes sub-sector & 820 \\
Chocolates sub-sector & 2176 \\
lce cream sub-sector & 1573 \\
\hline Confectionary sector & 5263 \\
Frozen desserts sector & 1879 \\
\hline
\end{tabular}


Table 4 Cost data along the life cycle of the products considered in the study

\begin{tabular}{|c|c|c|}
\hline Life cycle stage & Cost [£/unit] & Source \\
\hline \multicolumn{3}{|l|}{ Raw materials (ingredients) } \\
\hline Acetic acid & $0.46[£ / \mathrm{kg}]$ & ICIS (2015) \\
\hline Apples & $0.61[£ / \mathrm{kg}]$ & Office for National Statistics UK (2015) \\
\hline Butter & $1.94[£ / \mathrm{kg}]$ & DEFRA (2015) \\
\hline Citric acid & $0.79[£ / \mathrm{kg}]$ & ICIS (2015) \\
\hline Cocoa butter & $2.11[£ / \mathrm{kg}]$ & Niagara - Atlantic (2015) \\
\hline Cocoa liquor & $2.65[£ / \mathrm{kg}]$ & Niagara Atlantic Industries (2015) \\
\hline Cocoa powder & $2.85[£ / \mathrm{kg}]$ & Niagara Atlantic Industries (2015) \\
\hline Eggs pasteurised & $5.99[£ / \mathrm{kg}]$ & Bulk Powders (2015) \\
\hline Egg-yolk pasteurised & $10.95[£ / \mathrm{kg}]$ & Fine Food Specialist (2015) \\
\hline Flour white & $0.94[£ / k g]$ & Marriage's Master Millers (2015) \\
\hline Flour wholemeal & $1[£ / \mathrm{kg}]$ & Marriage's Master Millers (2015) \\
\hline Fructose - glucose & $3[£ / k g]$ & RealFoods (2015) \\
\hline Glycerine (vegetable) & $2.4[£ / \mathrm{kg}]$ & Darrant Chemicals (2015) \\
\hline Milk cream & $0.98[£ / \mathrm{kg}]$ & DairyCO (2015) \\
\hline Milk powder & $2.19[£ / \mathrm{kg}]$ & Index Mundi (2015) \\
\hline Palm kernel oil & $0.595[£ / \mathrm{kg}]$ & Index Mundi (2015) \\
\hline Palm oil & $0.37[£ / \mathrm{kg}]$ & Index Mundi (2015) \\
\hline Raw milk & $0.24[£ / \mathrm{kg}]$ & DairyCo (2015) \\
\hline Salt & $0.13[£ / \mathrm{kg}]$ & Credit Chem Group (2015) \\
\hline Soda & $0.33[£ / \mathrm{kg}]$ & ICIS (2015) \\
\hline Soft cheese & $2.28[£ / \mathrm{kg}]$ & DEFRA (2015) \\
\hline Sorbic acid & $79.19[£ / \mathrm{kg}]$ & ICIS (2015) \\
\hline Starch & $1.12[£ / k g]$ & RealFoods (2015) \\
\hline Strawberries & $2.26\left[\sum / \mathrm{kg}\right]$ & Office for National Statistics UK (2015) \\
\hline Sugar & $0.37[£ / \mathrm{kg}]$ & Index Mundi (2015) \\
\hline Vanilla extract & $155[£ / \mathrm{kg}]$ & Vanilla Mart (2015) \\
\hline Vanillin & $11.97[£ / \mathrm{kg}]$ & ICIS (2015) \\
\hline Whey powder & $1.064[£ / \mathrm{kg}]$ & Index Mundi (2015) \\
\hline Yeast & $9.36[£ / \mathrm{kg}]$ & RealFoods (2015) \\
\hline \multicolumn{3}{|l|}{ Manufacturing } \\
\hline Electricity & $0.079[£ / k W h]$ & DECC $(2015)$ \\
\hline Liquid ammonia $^{\mathrm{a}}$ & $0.33[£ / \mathrm{kg}]$ & Technicold Services (2015), ICIS (2015) \\
\hline Lubricant & $0.664[£ / \mathrm{kg}]$ & ICIS (2015) \\
\hline Natural gas & $0.019[£ / k W h]$ & DECC (2015) \\
\hline Nitric acid & $0.141[£ / \mathrm{kg}]$ & ICIS (2015) \\
\hline Sodium hydroxide & $0.416[£ / \mathrm{kg}]$ & ICIS (2015) \\
\hline Steam & $0.034[£ / \mathrm{MJ}]$ & $\operatorname{DECC}(2015)$ \\
\hline Water & $0.0016[£ / l]$ & United Utilities (2015) \\
\hline \multicolumn{3}{|l|}{ Packaging } \\
\hline Aluminium & $1.22[£ / k g]$ & LME (2015) \\
\hline Corrugated board & $0.14[£ / \mathrm{kg}]$ & LetsRecycle (2015) \\
\hline Folding box & $0.14[£ / \mathrm{kg}]$ & LetsRecycle (2015) \\
\hline Low density polyethylene & $1.57[£ / \mathrm{kg}]$ & Plastic Informat (2015) \\
\hline Paper & $0.14[£ / \mathrm{kg}]$ & LetsRecycle (2015) \\
\hline Plastic bags (retailer price) & $0.05[£ /$ piece $]$ & UK retailers \\
\hline Polypropylene & $1.69[£ / \mathrm{kg}]$ & Plastic Informat (2015) \\
\hline \multicolumn{3}{|c|}{ Distribution centre, retail and consumption } \\
\hline Electricity & $0.079[£ / k W h]$ & DECC (2015) \\
\hline Water & $0.0016[£ / l]$ & United Utilities (2015) \\
\hline Refrigerant $(\mathrm{R} 134 \mathrm{a})^{\mathrm{b}}$ & $12.8[£ / \mathrm{kg}]$ & Schmidt \& Azapagic (2014) \\
\hline Electricity (domestic) & $0.152[£ / k W h]$ & Ofgem (2015) \\
\hline Detergent & $6.65[£ / \mathrm{kg}]$ & Tesco (2015) \\
\hline \multicolumn{3}{|l|}{ Transport } \\
\hline Fuel for passenger car ${ }^{\mathrm{C}}$ & $1.208[£ / l]$ & Global Petrol Prices (2014) \\
\hline Transoceanic tanker & $0.0025[£ / \mathrm{km}]$ & VTT (2010), Global Petrol Prices (2014) \\
\hline Transport (16 t lorry) & $0.00003[£ / \mathrm{kg} \mathrm{km}]$ & DECC (2015), VTT (2010) \\
\hline \multicolumn{3}{|l|}{ Waste management } \\
\hline Wastewater treatment & $0.0013[£ / l]$ & United Utilities (2015) \\
\hline Landfilling & $0.1[£ / l]$ & WRAP (2015) \\
\hline Energy recovery & $0.99[£ / \mathrm{kg}]$ & WRAP (2015) \\
\hline Recycling & $0.06[£ / \mathrm{kg}]$ & WRAP (2015) \\
\hline Organic waste & $0.046[£ / \mathrm{kg}]$ & WRAP (2015) \\
\hline
\end{tabular}




\subsubsection{Life cycle cost data}

Life cycle cost data for individual products have been collected from manufacturers, literature and other publicly available sources. These are summarised in Table 4, which lists costs of all flows and activities across the 18 products considered in the study, together with the data sources. A detailed breakdown of ingredients and costs by product can be found in Table S2 in the SI. Where possible, all cost data are representative of UK conditions in 2015. In the case of multi-function or multi-output systems, the costs have been allocated on an economic basis. The savings (system credits) correspond to the market prices of recycled materials (see Table S2).

To estimate the LCC and VA at the sectoral level, it has been necessary to define sales volumes and typical retail prices. Due to a lack of data on the sales volumes, these have been estimated based on the annual monetary value (Key Note 2015a-c). These values have been divided by the typical retail prices of each product in the UK at three major UK supermarkets (Tesco, 2015; Sainsbury's, 2015; Morrison, 2015) to obtain an estimated sales volume for each product in mass terms (Table S1). The retail prices and the derived annual sales volumes are given in Table 5 . In the case of different retail prices for the same product, the lowest price has been adopted. Thus, following a conservative approach, the highest possible sales volumes have been considered.

In the estimation of the sales volumes, it has been assumed that cupcakes, pies and cake slices have equal sales value as their individual share of the market is not known. In a similar fashion, semi-sweet and vanilla cream biscuits are also presumed to have the same sales values. The same assumption applies for chocolate-coated and chocolate cream biscuits as only the total sales of chocolate-containing biscuits are available but not their individual shares. For ice cream, the same sales of vanilla and chocolate flavour are considered. Any other products that could not be assigned to the existing product categories have been allocated to the 'other' category. Taking a conservative approach, their LCC are assumed to be equal to the highest cost to the retailer in each product category.

Table 5 Product sales prices and estimated annual sales volumes

\begin{tabular}{|c|c|c|c|c|}
\hline Category & Products & $\begin{array}{c}\text { Retail price } \\
{[\varepsilon / \mathrm{kg}]}\end{array}$ & $\begin{array}{c}\text { Sales value } \\
\text { [£m/yr] }\end{array}$ & $\begin{array}{c}\text { Sales volume } \\
{[t / y r]}\end{array}$ \\
\hline \multirow[t]{8}{*}{ Biscuits } & Crackers & 1.3 & 362 & 278,462 \\
\hline & Low fat/sugar & 1.5 & 612 & 408,000 \\
\hline & Semi-sweet & 1.1 & 281.5 & 255,909 \\
\hline & Chocolate coated & 2 & 208.5 & 104,250 \\
\hline & Vanilla cream & 6.4 & 281.5 & 43,984 \\
\hline & Chocolate cream & 6.5 & 208.5 & 32,077 \\
\hline & Other biscuit products ${ }^{a}$ & 1.1 & 654 & 594,545 \\
\hline & Total & & 2608 & $1,717,227$ \\
\hline \multirow[t]{6}{*}{ Cakes } & Whole cakes & 6.8 & 287 & 42,206 \\
\hline & Cake slices & 8 & 362.3 & 45,288 \\
\hline & Pies & 2 & 362.3 & 181,150 \\
\hline & Cupcakes & 13 & 362.3 & 27,869 \\
\hline & Cheesecakes & 4.3 & 272 & 63,256 \\
\hline & Total & & 1646 & 359,769 \\
\hline \multirow[t]{5}{*}{ Chocolates } & Moulded chocolate & 7.5 & 845 & 112,667 \\
\hline & Chocolate countlines & 6 & 1817 & 302,833 \\
\hline & Chocolates in bags & 8.3 & 1304 & 157,108 \\
\hline & Other chocolate products ${ }^{\mathrm{b}}$ & 6 & 378 & 63,000 \\
\hline & Total & & 4344 & 635,608 \\
\hline \multirow[t]{6}{*}{ Ice cream } & Vanilla regular & 2 & 55 & 27,500 \\
\hline & Chocolate regular & 2 & 55 & 27,500 \\
\hline & Vanilla premium & 5 & 221.5 & 44,300 \\
\hline & Chocolate premium & 5 & 221.5 & 44,300 \\
\hline & Other ice cream products ${ }^{c}$ & 2.225 & 580 & 260,674 \\
\hline & Total & & 1133 & 404,274 \\
\hline
\end{tabular}

\footnotetext{
Seasonal, savoury, children and special treats (Key Note 2015a) report.

Seasonal products and novelties (Key Note, 2015b).

${ }^{c}$ Other than take-home ice creams (Key Note 2015c).
} 


\section{Results and discussion}

This section first presents the LCC and VA estimates by product type, followed by sensitivity and uncertainty analyses. The latter part of the section discusses the LCC and VA estimates at the sectoral level.

\subsection{Economic sustainability at the product level}

Among the product categories considered, cakes are found to have the highest LCC, followed by ice cream, chocolates and finally biscuits (Fig. 3-Fig. 6). These findings are discussed below by product category.

\subsubsection{Life cycle costs of biscuits}

The total life cycle costs of biscuits and the contribution of different stages are shown in Fig. 3 . The most costly product is crackers $(£ 0.91 / \mathrm{kg})$ while the vanilla cream biscuits are the least expensive $(£ 0.72 / \mathrm{kg})$. The costs of all other biscuits are within approximately $15 \%$ of each other. The raw materials have the highest contribution to the total costs, ranging between $79 \%$ and $86 \%$. This is mainly due to flour, milk and cocoa powder, palm oil and sugar, with flour alone contributing on average $50 \%$ of the total (see Table S2). While the unit cost of flour is quite low $(£ 0.94 / \mathrm{kg})$, it makes up the majority of the mass of the biscuits which explains its high overall contribution to the total cost.

Manufacturing contributes $6 \%-7 \%$, mainly due to energy consumption in the production process. This is followed by packaging with $4 \%-6 \%$, except for crackers where it accounts for $11 \%$. The latter is due to the use of more packaging material per mass of product compared to the other types of biscuit, leading to their highest overall LCC in this product category. The rest of the costs $(3 \%-4 \%)$ are due to transport. Crediting the system for endof-life packaging recycling and energy recovery reduces the costs by only $1 \%-3 \%$ (Table S3).

\subsubsection{Life cycle costs of cakes}

The results in Fig. 4 indicate that whole cakes are the most costly products $(£ 2.64 / \mathrm{kg})$ with a total LCC $42 \%$ higher than the lowest cost, estimated for pies $(£ 1.52 / \mathrm{kg})$.

More than any of the other product categories, cakes are dominated by the raw material costs, which account for $80 \%-94 \%$ of the total LCC. Pasteurised eggs, fructose/glucose sweetener, butter, flour, strawberry, milk powder and palm oil contribute most to the costs of ingredients (Table S3). Eggs are the biggest individual cost component, accounting for an average of $43 \%$ across the products. The only exception is cheesecake which does not include eggs, where milk powder and soft cheese together account for $53 \%$ of the total LCC.

The second most contributing stage is packaging, with noteworthy contributions to the costs of cupcakes (12.8\%) and pies (7\%). Cupcakes benefit from some cost savings (3\%) due to a greater amount of energy recovered from the incinerated packaging, related to a higher amount of packaging used for these products.

\subsubsection{Life cycle costs of chocolates}

The LCC of chocolate products are presented in Fig. 5 which reveals that chocolates in bags are the most expensive product type $(£ 1.46 / \mathrm{kg})$, followed closely by moulded chocolates $(£ 1.41 / \mathrm{kg})$. By comparison, chocolate countlines cost $£ 1.16 / \mathrm{kg}$.

Raw materials again dominate the LCC, accounting for $89 \%-94 \%$ of the total, with milk powder, cocoa butter and liquor as well as sugar being the most relevant ingredients (see Table S2). Milk powder is the greatest single contributor, accounting for an average of $35 \%$ of the LCC. It can also be noted in Fig. 5 that the cost of packaging is over three times higher for chocolates in bags than for the moulded chocolates, despite their packaging materials being very similar. This is due to the bagged chocolates requiring more packaging per unit of product. However, in comparison with raw materials, packaging and other stages have 
insignificant contributions to the LCC. Further details on the contribution analysis can be found in Table S3.

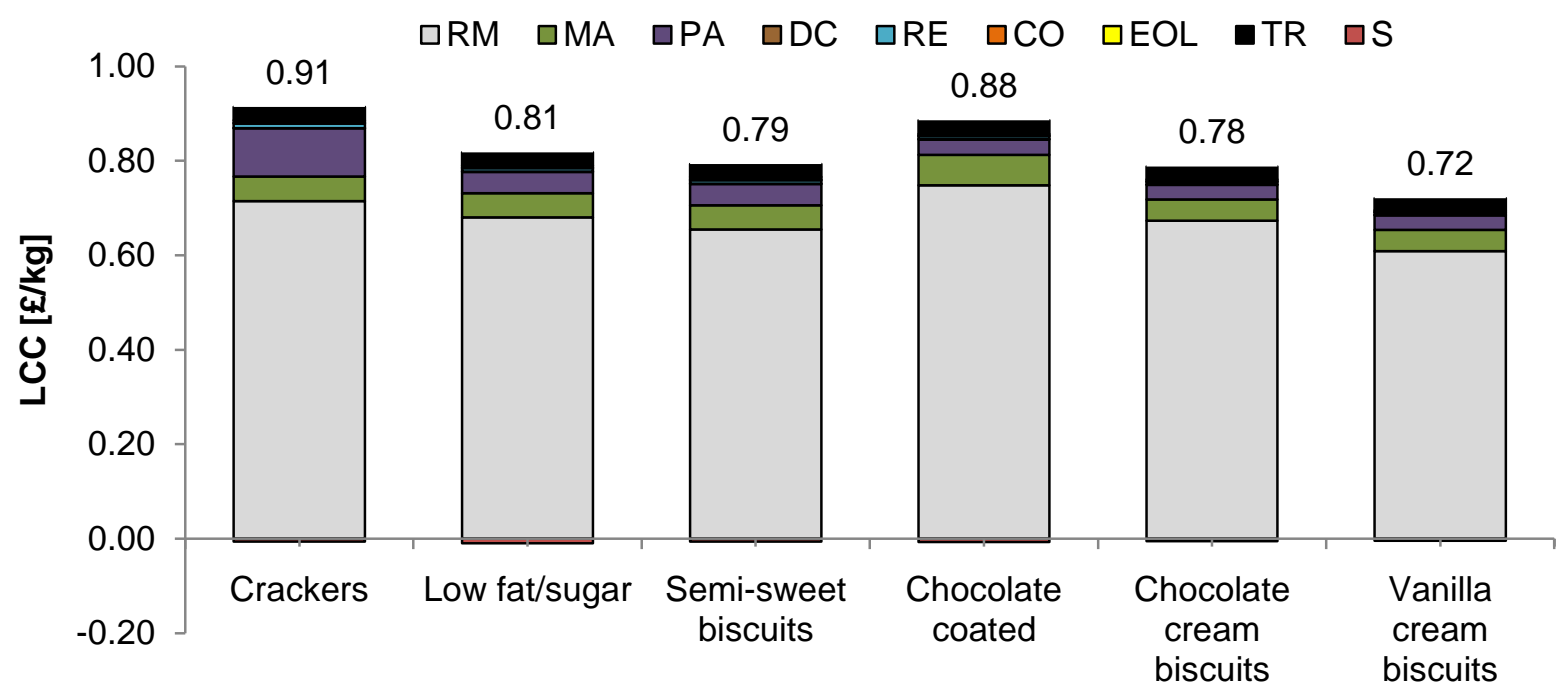

Fig. 3 Life cycle costs (LCC) of biscuits [RM: raw materials; MA: manufacturing; PA: packaging; RE: retail; CO: consumption; EoL: end-of-life waste management; TR: transport;

S: savings (system credit for EoL)].

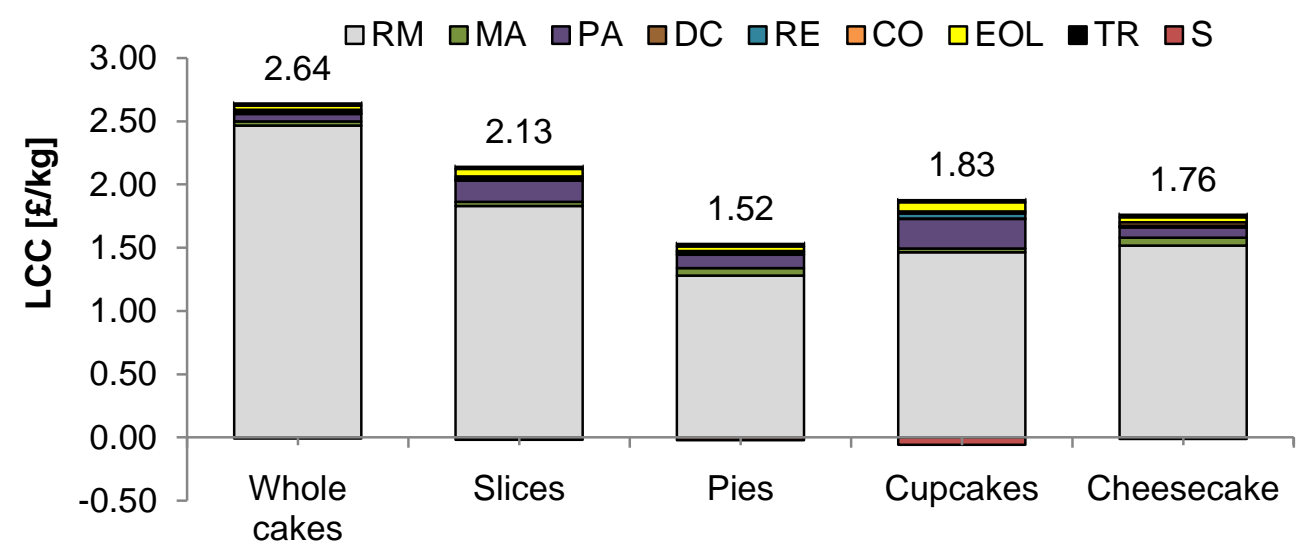

Fig. 4 Life cycle costs (LCC) of cakes [For the legend, see Fig. 3.].

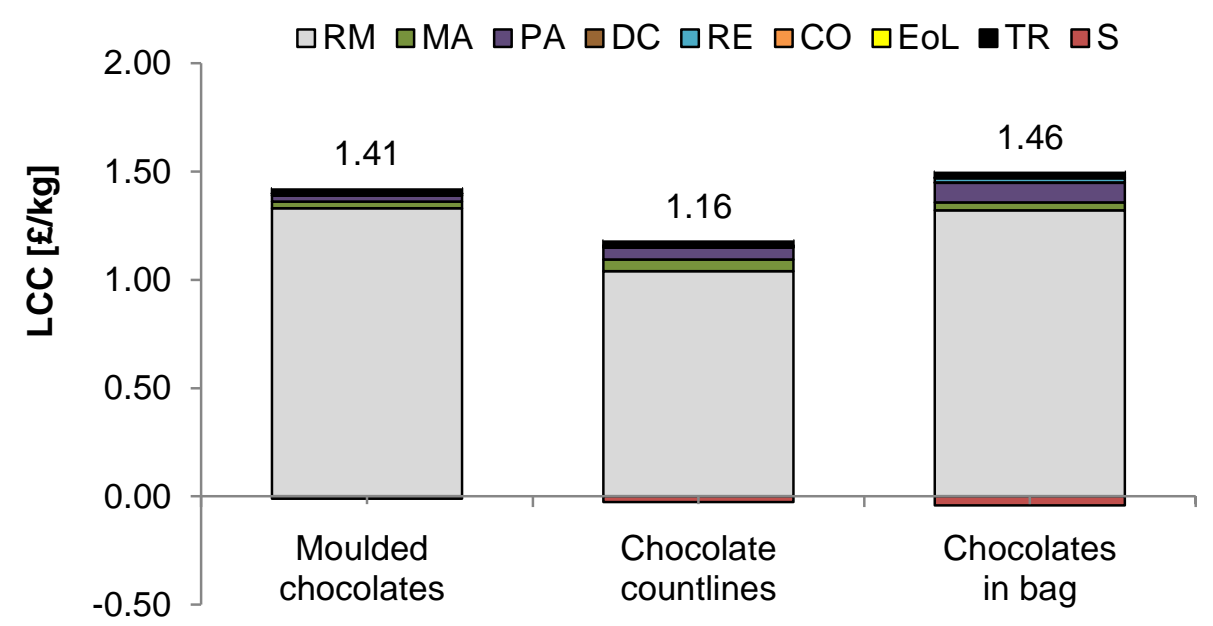

Fig. 5 Life cycle costs (LCC) of chocolates [For the legend, see Fig. 3.]. 


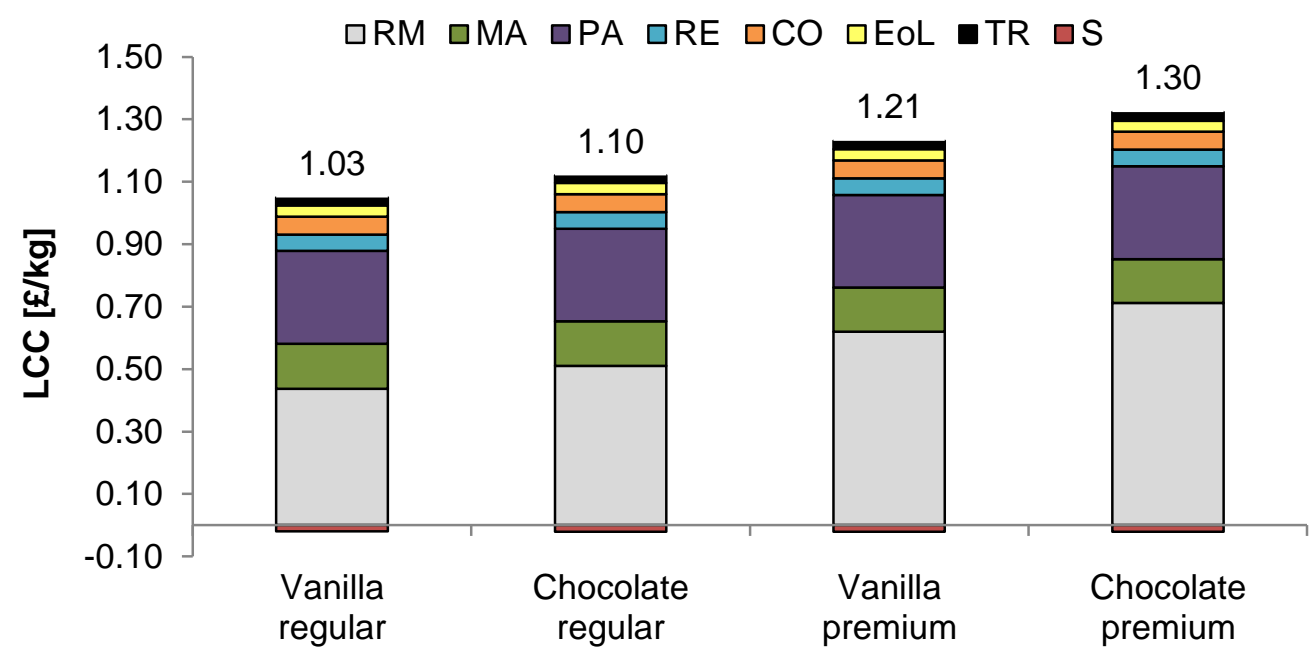

Fig. 6 Life cycle costs (LCC) of ice cream [For the legend, see Fig. 3.].

\subsubsection{Life cycle costs of ice cream}

As indicated in Fig. 6, chocolate premium ice cream has the highest LCC $(£ 1.30 / \mathrm{kg})$ while vanilla regular is the least costly $(£ 1.03 / \mathrm{kg})$. This difference is entirely attributable to the raw materials: premium chocolate ice cream contains egg yolk and cocoa, which are expensive ingredients (Table S2) and not used in the regular varieties. It also has a $27 \%$ higher amount of sugar compared to the vanilla regular product.

Across all four types of ice cream, production of raw materials is the most expensive life cycle stage $(43 \%-55 \%$ of the total), mainly due to milk $(30 \%-37 \%)$. Packaging is the next significant stage, with contributions ranging from $23 \%-29 \%$, largely due to the polypropylene tub. Manufacturing is the third biggest contributor $(11 \%-14 \%)$ with energy consumption accounting for $10 \%-13 \%$ of the total costs, the vast majority of which is related to electricity usage. The retail stage contributes $4 \%-5 \%$ of the total LCC, mostly caused by energy consumption for refrigeration. The contribution of the consumption stage is similar to retail $(4 \%-6 \%)$, mainly due to energy consumed by the freezer and hot water used to wash the used dishes. Crediting the system for packaging recycling and energy recovery saves $£ 0.020-0.022 / \mathrm{kg}$ ice cream, reducing the total LCC by $2 \%$. For further details on the contribution of different life cycle stages to the costs, see Table S3.

\subsubsection{Costs to different stakeholders and value added}

The LCC to manufacturers, retailers and consumers are shown for each product in Fig. 7. These have been estimated using eqns. (2)-(4), based on the system boundaries outlined in Fig. 2. Fig. 7 also provides the VA by product type, obtained via eqn. (5), using the LCC discussed in the previous sections and the sales prices of the products in Table S2. Further details on the costs to different stakeholders and VA can be found in Table S4.

As can be inferred from Fig. 7, the costs to the biscuit manufacturers are $4.7 \%-7.3 \%$ lower than their respective total LCC. A similar difference is found for cakes $(4 \%-8.5 \%)$, while for chocolates the differential is only $2 \%$. By contrast, the costs of ice cream manufacture are $23 \%-30 \%$ lower than the total LCC, largely due to the additional refrigeration beyond the manufacturer's gate.

Costs to retailers are higher with respect to manufacturers' costs on average by $1.5 \%$ for all product categories but the ice cream (7\%); the latter is again due to refrigeration. Finally, costs to consumers relative to retailers are on average $20 \%$ higher for ice cream and, for the other products, they are greater by $1 \%$ to $6 \%$.

The highest VA is found for the cupcakes, estimated at $£ 11.28 / \mathrm{kg}$ (Fig. 7a). This is due to the low costs of ingredients and high retail price per kg relative to the other cake types. The next highest VA is for chocolates in bags with $£ 6.84 / \mathrm{kg}$ and moulded chocolates with $£ 6.11 / \mathrm{kg}$ 
(Fig. 7b). They both command high retail prices ( $£ 8.3$ and $£ 7.5$ per $\mathrm{kg}$ ) and have low retailer's LCC ( $£ 1.46$ and $£ 1.39 / \mathrm{kg}$ ), hence the high VA. At the other end of the scale, the lowest VA, found for semi-sweet biscuits, is 30 times lower than that of the cupcakes. This type of biscuit has a low retail price $(£ 1.10 / \mathrm{kg})$ and, despite only a moderate retailer's LCC $(£ 0.75 / \mathrm{kg})$, generates only $£ 0.35 / \mathrm{kg}$ in VA. The other products with a relatively low VA are crackers $(£ 0.44 / \mathrm{kg})$ and pies $(£ 0.55 / \mathrm{kg})$. Among the biscuits, the highest VA is found for the vanilla and chocolate cream varieties $(\sim £ 5.75 / \mathrm{kg})$ and, among the ice cream, for the premium products $(\sim £ 4 / \mathrm{kg})$.

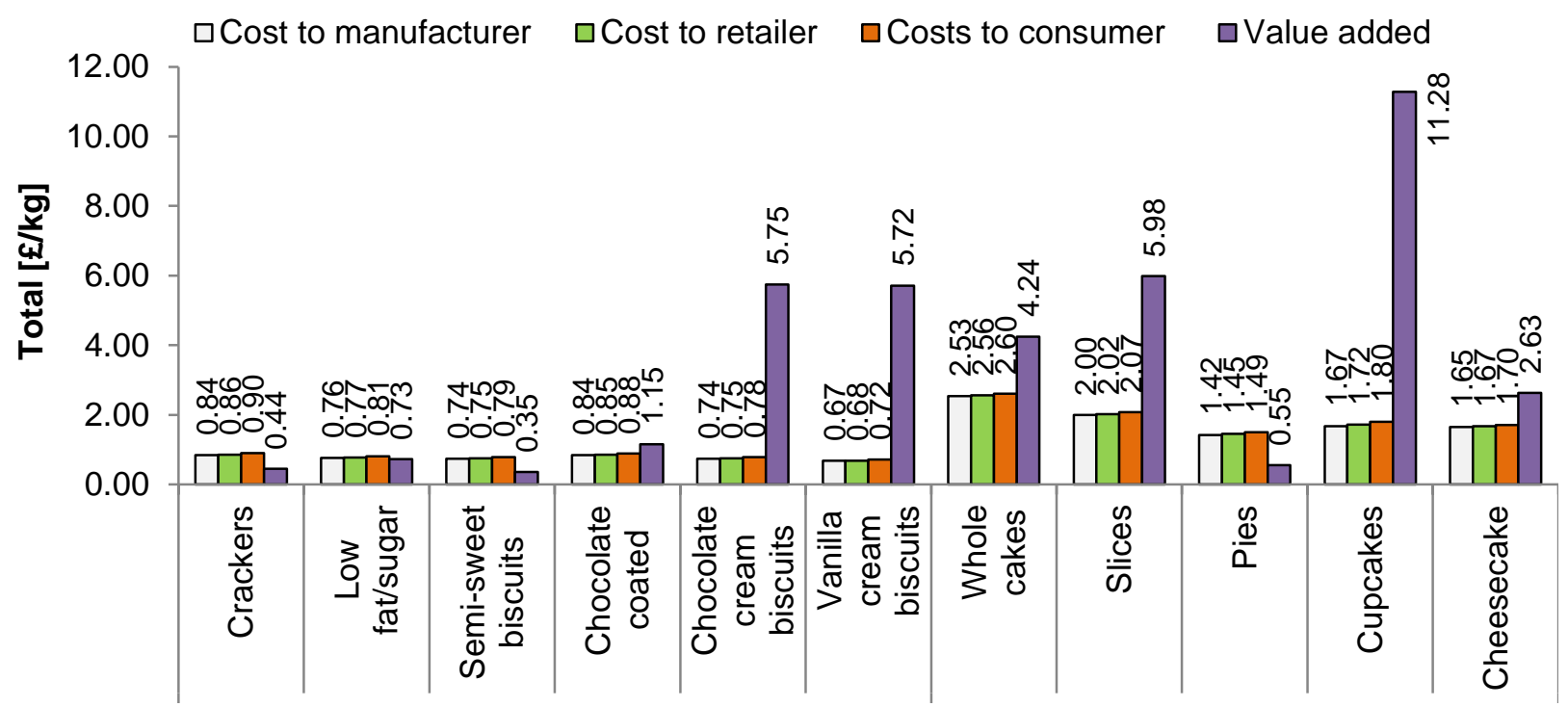

a) Biscuits and cakes

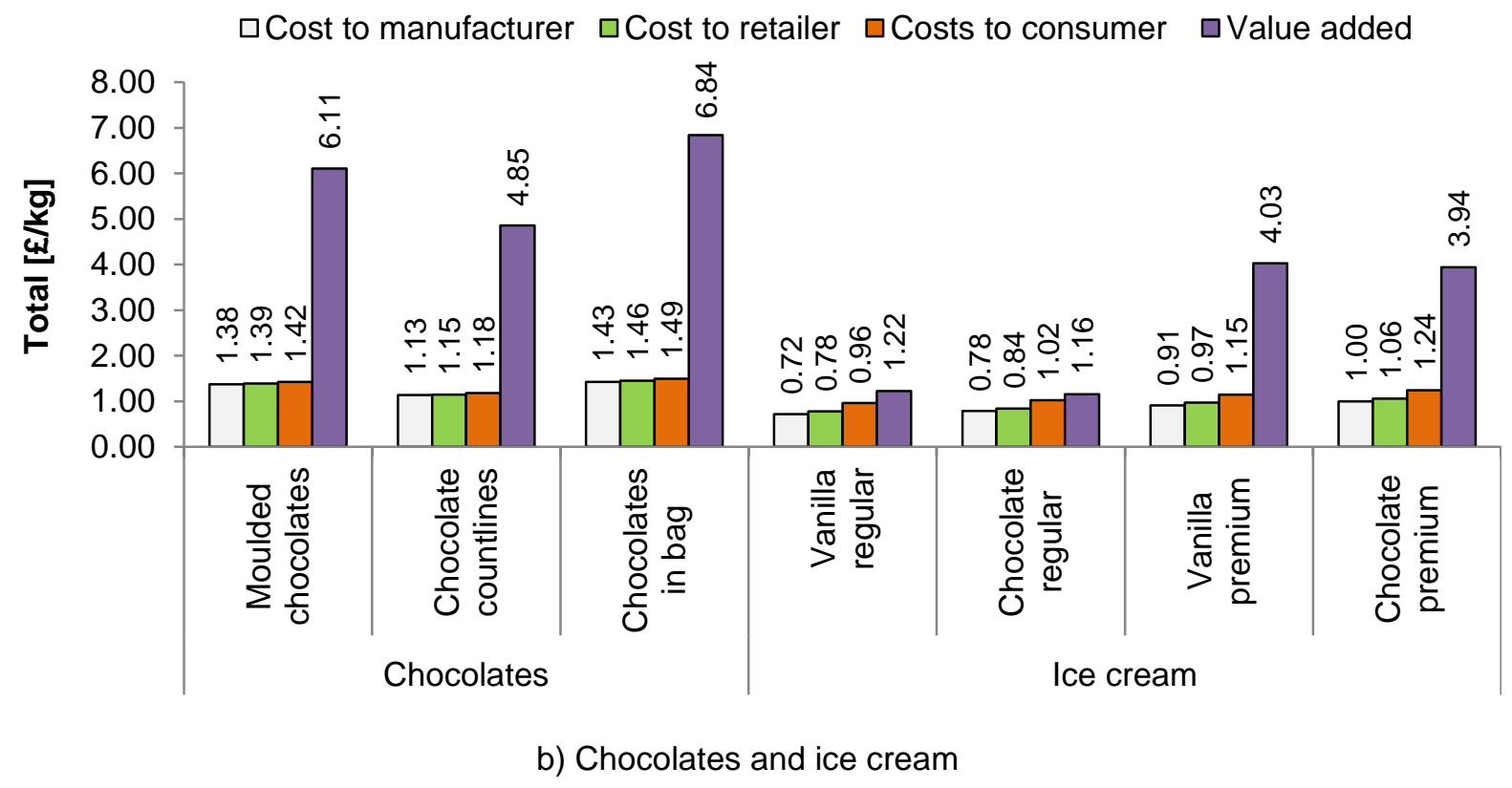

Fig. 7 Life cycle costs to different stakeholders and value added by product 


\subsubsection{Sensitivity analysis}

Given the high contribution of raw materials across the products, and the packaging for ice cream, these two life cycle stages are the focus of the sensitivity analysis as discussed below. The effect on the LCC of energy consumption in the manufacturing, retail and use stages is explored.

\subsubsection{Raw materials}

Loss of raw materials in manufacturing can be highly variable. In the base case presented above, manufacturing losses have been assumed at $2 \%$. In the sensitivity analysis, two cases are examined, one assuming $5 \%$ and another $10 \%$ losses of raw materials. The results are shown in Fig. 8, expressed relative to the base case costs.

If the manufacturing losses increase from $2 \%$ to $5 \%$, the overall LCC increase by around $1 \%$ for ice cream and up to $3 \%$ for the remaining products. When losses are assumed to be $10 \%$, the costs go up by $3 \%-4 \%$ for ice cream, $4 \%-8 \%$ for biscuits and $6 \%-8 \%$ for chocolates and cakes. Hence, a five-fold increase in raw material losses increases the overall LCC by only 3\%-8\%. Nevertheless, production losses have an obvious adverse effect on both the economic and environmental sustainability and should be minimised as much as possible.

\subsubsection{Packaging losses in ice cream manufacturing}

To examine how manufacturing losses in ice cream packaging influence the LCC, it is assumed that $5 \%$ and $10 \%$ of packaging is lost in manufacturing instead of $2 \%$ assumed in the base case. The results in Fig. 9 suggest very low influence of packaging losses on the total LCC. An increase in the packaging losses from $2 \%$ to $5 \%$ increases the LCC at most by $1.5 \%$, while an increase to $10 \%$ changes the total by $3 \%$. Therefore, the total costs are not sensitive to packaging wastage. However, generation of waste is undesirable and should be kept as low as possible.

\subsubsection{Energy}

The effect on the LCC of energy used in the manufacturing, retail and use stages is explored by varying the total energy consumption by $\pm 20 \%$. As Fig. 10 indicates, the relationship between energy and life cycle costing is stronger in the case of ice cream than for the other products. This is attributable to the refrigeration energy used in the life cycle of ice cream. However, the total LCC of ice cream only changes by $\pm 3 \%$. The LCC of the other products is altered by $\pm 0.2-1.4 \%$, with the latter referring to chocolate-coated biscuits. Nevertheless, despite this low variation in the overall LCC with energy consumption, the cost reductions are likely to be significant on an annual basis. 


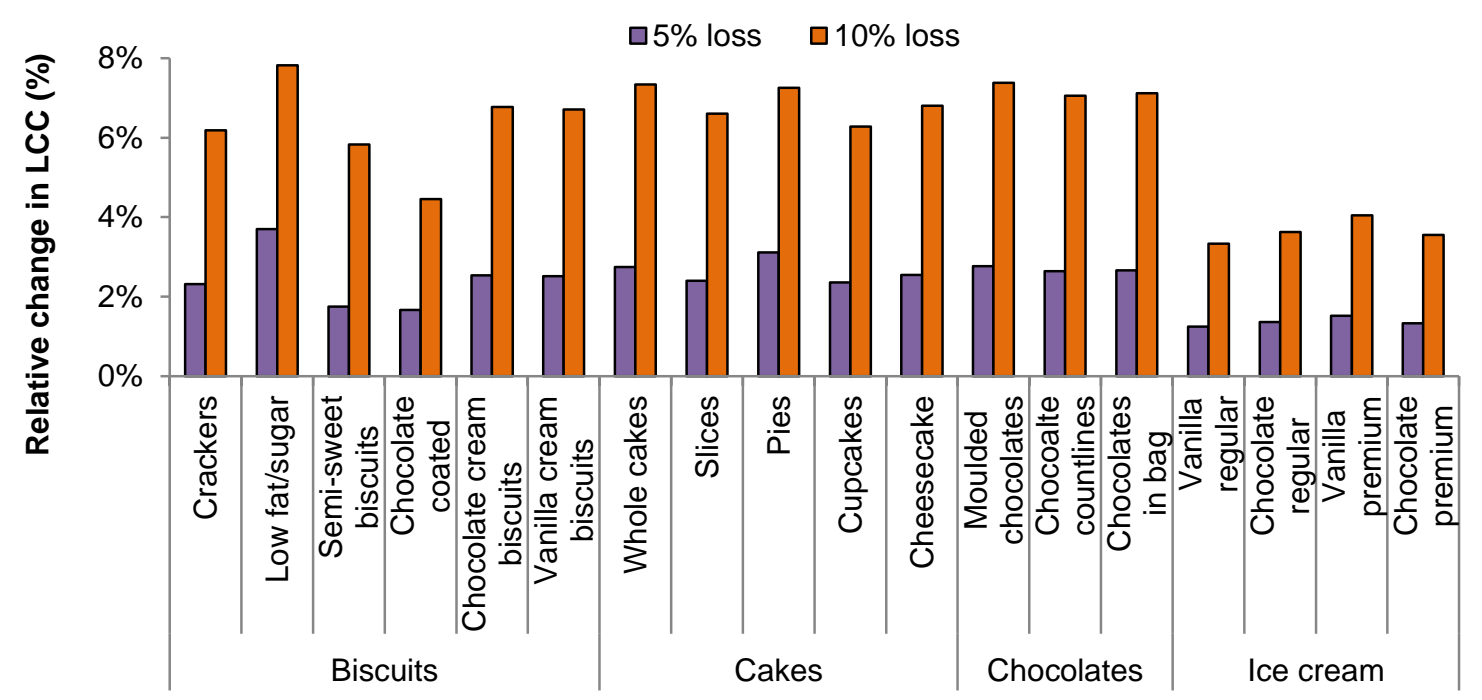

Fig. 8 The effect on the life cycle costs (LCC) of increasing raw materials losses in manufacturing relative to the base case losses (2\%).

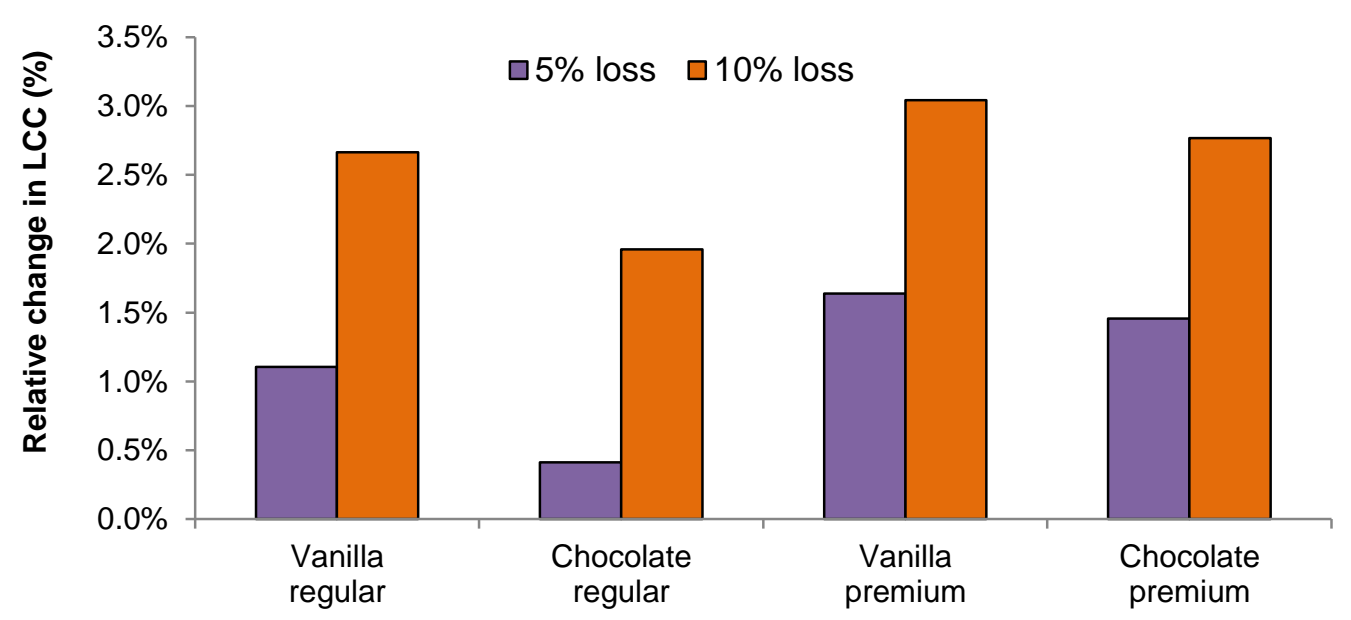

Fig. 9 The effect on the life cycle costs (LCC) of increasing packaging losses for ice cream relative to the base case losses (2\%). 


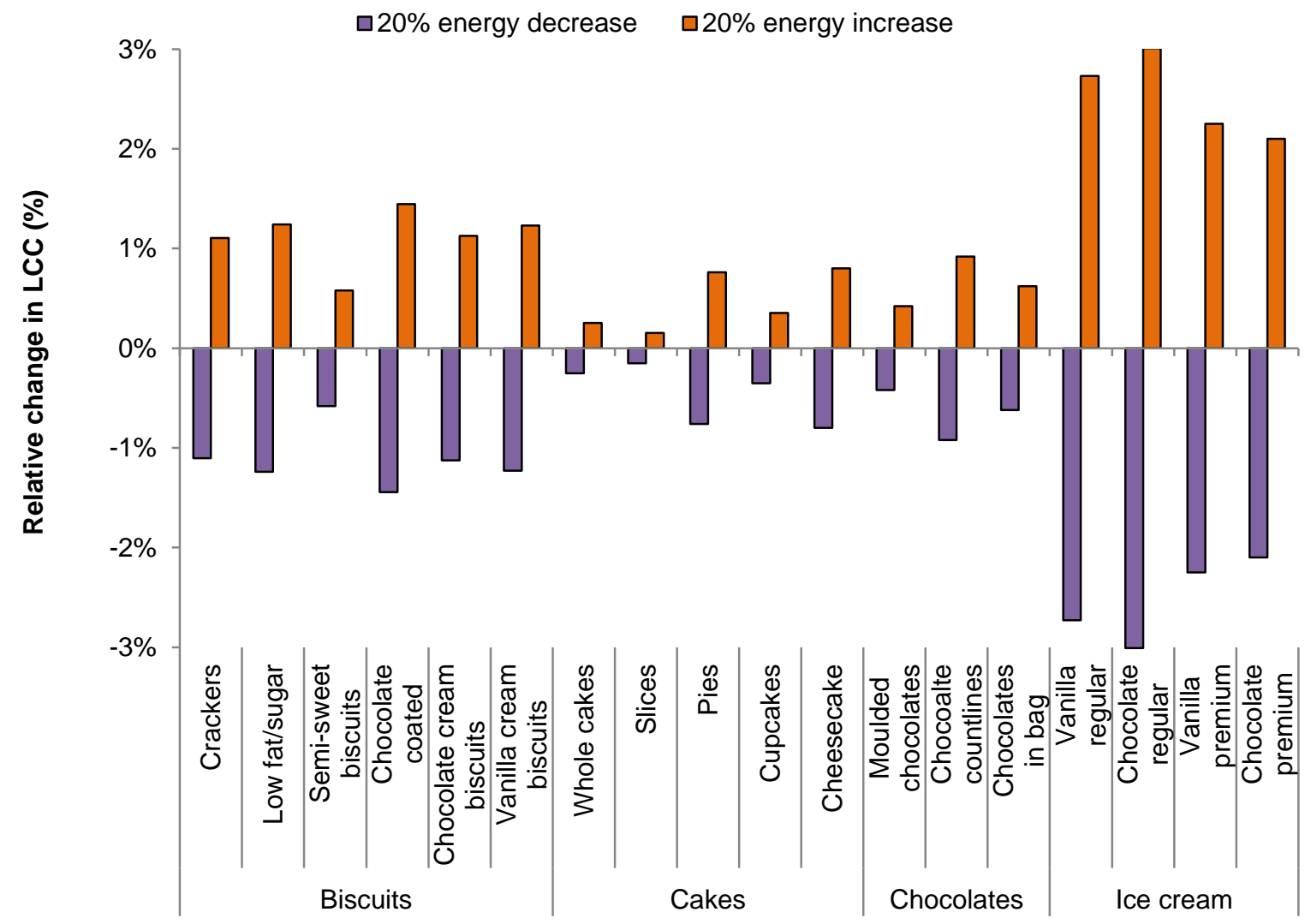

Fig. 10The effect on the life cycle costs (LCC) of the variation in energy consumption in manufacturing and distribution.

\subsubsection{Uncertainty analysis}

In addition to the uncertainties explored in the sensitivity analysis, the uncertainty analysis also considers potential price changes across the life cycle. A variation of $\pm 25 \%$ over a threeyear period is considered to capture sizeable year-on-year price swings.

The uncertainty analysis has been carried out through Monte Carlo simulation using @RISK7 software (Palisade, 2017). A total of 20,000 iterations have been performed for each product using the PERT distribution for each distinct parameter and considering a 95\% confidence interval. This type of distribution has been selected because it places equal emphasis on the minimum and maximum values in the range, which are normally less well-known than the most likely value.

The results in Fig. 11 and Table S5 reveal that the LCC could vary by $\pm 12 \%$ (chocolates in bags and chocolate premium ice cream) to $19 \%$ (low fat/sugar biscuits). However, their ranking in terms of costs remains unchanged: cakes maintain their position as the most costly product category, followed by ice cream, chocolates and finally biscuits.

\subsection{Economic sustainability at the sectoral level}

This section presents the LCC and VA at the sectoral level, estimated using the LCC and VA of the individual products discussed in sections 3.1.1-3.1.4 and their annual sales volumes given in Table 5. The total LCC at the sectoral level are estimated at £3.455 billion/yr (Fig. 12 and Table S6). Biscuits contribute most to the total costs $(41 \%)$ due to their high sales volumes ( 1.72 million $\mathrm{t} / \mathrm{yr}$ ). They are followed by chocolates, accounting for $23 \%$ of the total although their sales volume is much lower (636 kt/yr), they have a higher average cost per $\mathrm{kg}$ (see previous sections). Cakes and ice cream contribute $19 \%$ and $15 \%$ to the total costs, respectively. 


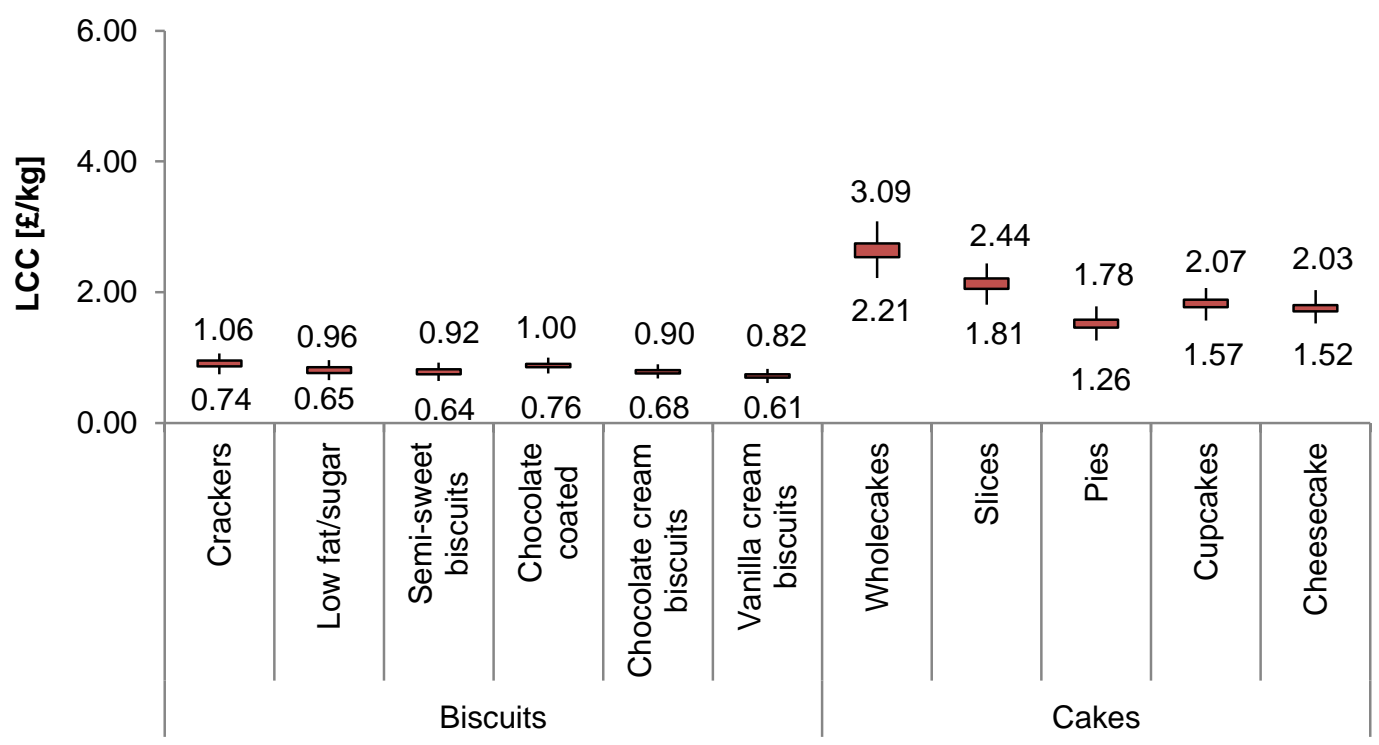

a) Biscuits and cakes

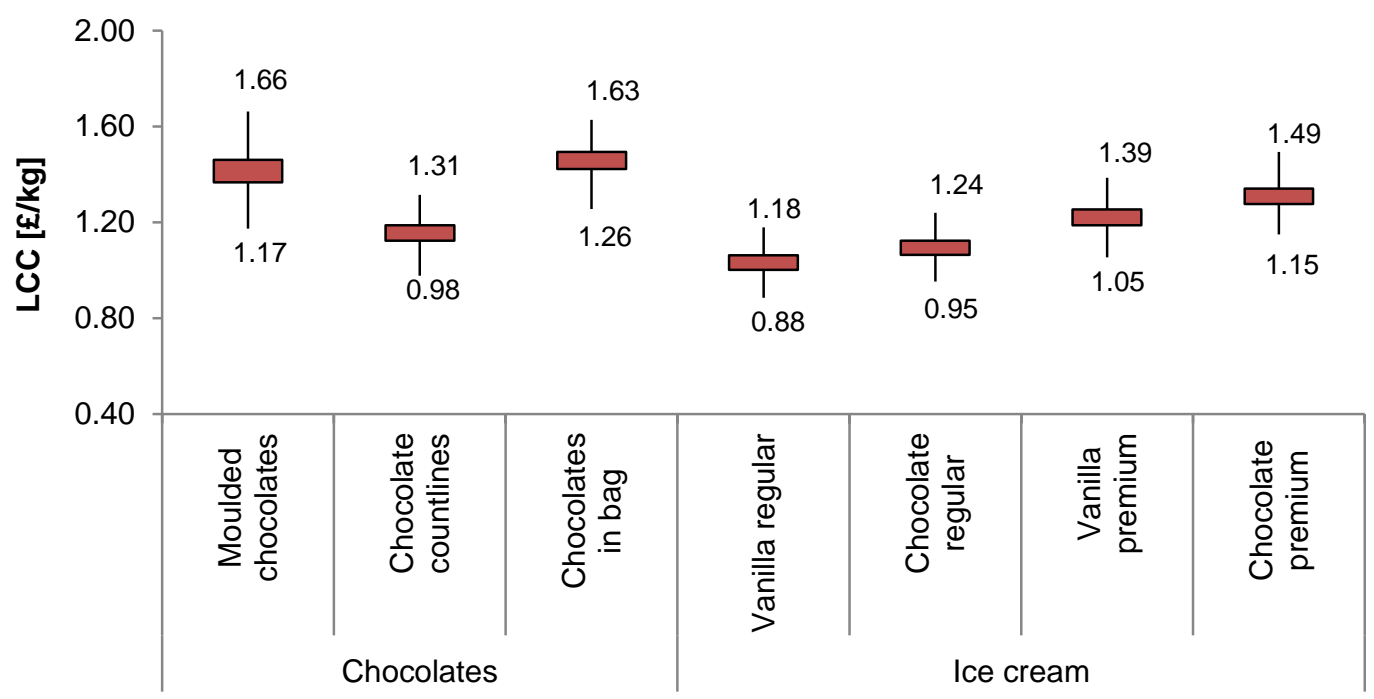

b) Chocolates and ice cream

Fig. 11 Uncertainty analysis for the four product categories considered in the study [Parameters varied: raw material and packaging losses in manufacturing, energy consumption and costs across the life cycle of products]. 


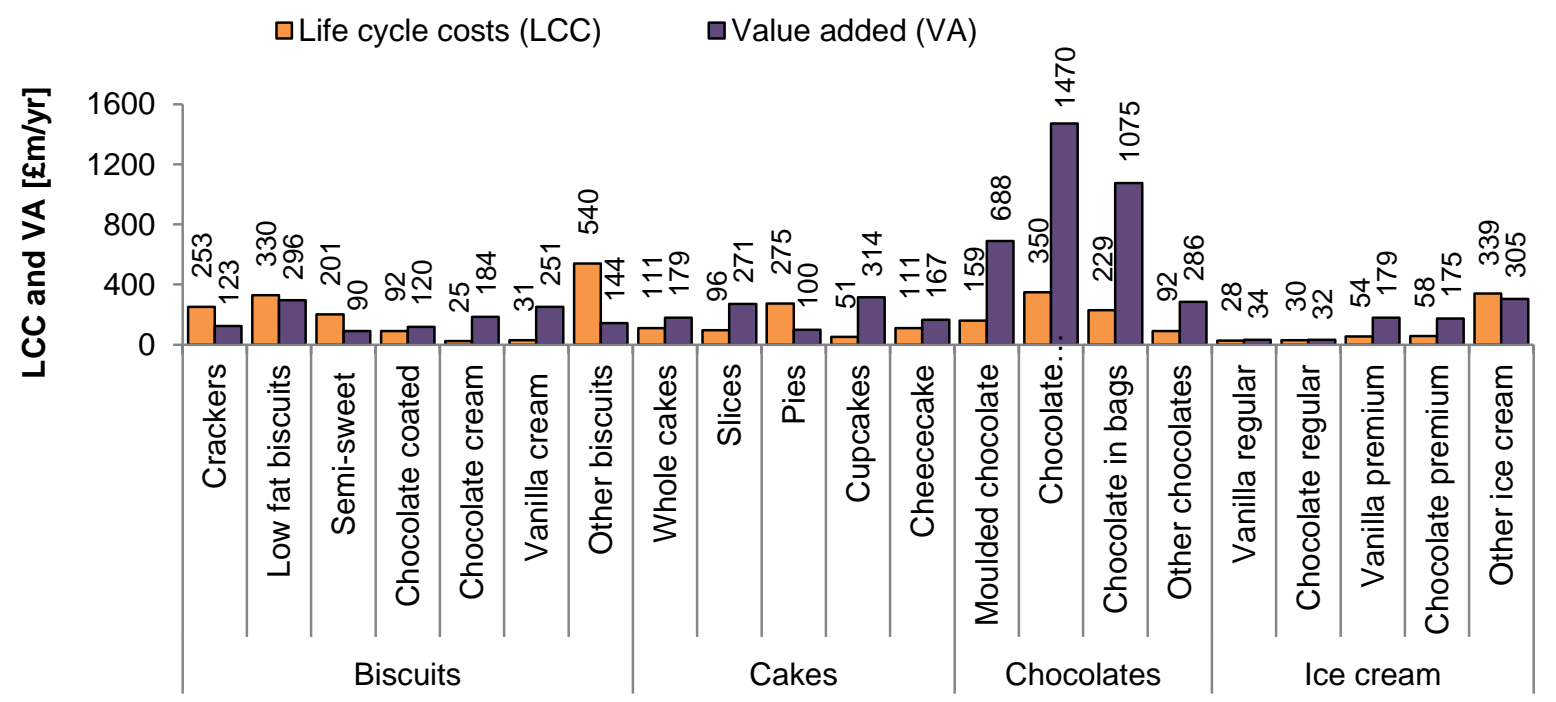

Fig. 12Annual life cycle costs (LCC) and value added (VA) at the sectoral level.

The total VA per year is equivalent to $£ 6.483$ billion, of which chocolates account for $54 \%$ (Fig. 12 and Table S6). Within this product category, chocolate countlines generate the most value ( $£ 1.47$ billion/yr) due to the combination of high sales volumes, high retail prices and relatively low costs (see section 3.1.5). Overall, chocolates have a five-fold higher VA than ice cream (which accounts for $11 \%$ of the total sectoral VA), three times higher than biscuits $(19 \%)$ and more than three times greater than cakes (16\%). Although ice cream creates the lowest total VA at the sectoral level, it is notable that the premium versions generate four times the value of their respective regular counterparts as they command a $150 \%$ higher retail price despite their similar costs per unit.

The above results are contextualised in Fig. 13 against the sales values (Key Note, 2015a-c) of the four product categories considered. As indicated in the figure, the annual LCC of biscuits contribute around $55 \%$ to their total sales value, with the rest representing the VA. The share of the LCC in the sales value of cakes is lower, estimated at $38 \%$, and thus the contribution of VA to the total is somewhat higher than for biscuits. The split between the LCC and the VA for ice cream is similar to that of cakes, with the former accounting for $41 \%$ of the sales value and the VA for $59 \%$.

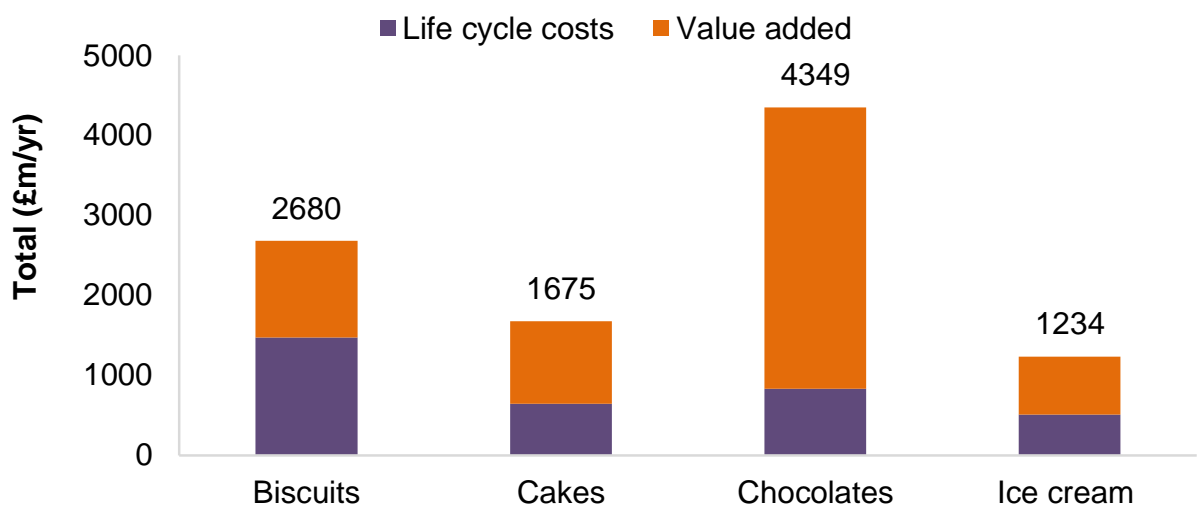

Fig. 13Annual sales of products by value, showing contributions of the life cycle costs and value added to the total. 
Chocolates, on the other hand, have a much lower LCC contribution (19\%) than the other products; therefore, their VA is considerably higher (81\%), making chocolates economically the most efficient sector.

The total sales value in these four sectors estimated in this work is $£ 9.938$ billion - this differs only by $2 \%$ from the value of $£ 9.731$ billion reported by Key Note $(2015 a-c)$, instilling further confidence in the results. Overall, the estimated LCC of $£ 3.455$ billion account for $35 \%$ of the total sales and VA the remaining $65 \%$.

\subsection{Eco-efficiency at the product and sectoral levels}

To put the economic performance in context, this section considers eco-efficiency of the products and sectors relative to their environmental performance. As explained in Section 2.2.3, global warming potential is considered for these purposes.

The estimated eco-efficiencies of the different products considered in the study are illustrated in Fig. 14. As can be seen, whole cakes are the most eco-efficient product type with an ecoefficiency of $0.77 \mathrm{~kg} \mathrm{CO}$ eq./£, while vanilla regular ice cream has the lowest eco-efficiency of $3.64 \mathrm{~kg} \mathrm{CO}$ eq./£. The cakes are generally most eco-efficient: although they have high LCC, their GWP is relatively low, leading to a lower score and, therefore, higher ecoefficiency. The exception to this is cheesecake which is ranked $13^{\text {th }}$ out of 18 products due to its high GWP - more than two times higher than that of whole cakes (Table 2).

Biscuits are the second most eco-efficient products with respect to GWP, with the crackers being the best and chocolate-coated biscuits the worst in this category $(1.44$ and $2.06 \mathrm{~kg}$ $\mathrm{CO}_{2}$ eq./£, respectively). Chocolates are ranked third overall, with the eco-efficiency values in the range of 2.4 and $2.84 \mathrm{~kg} \mathrm{CO}$ eq./£. The ice cream is the least efficient product category due to the high GWP, leading to 2.5-4.7 times worse eco-efficiency than the cakes (3.01$3.64 \mathrm{~kg} \mathrm{CO}$ eq./£).

The above results are also reflected at the sectoral level, with the cakes sub-sector being the most eco-efficient at $1.3 \mathrm{~kg} \mathrm{CO}$ eq./ $£$ and the ice cream the least efficient with $3.1 \mathrm{~kg} \mathrm{CO}$ eq./£ (Fig. 15). Biscuits and chocolates are ranked $2^{\text {nd }}$ and $3^{\text {rd }}$, respectively. Overall, as indicated in Fig. 15, the confectionary sector is around $60 \%$ more eco-efficient than the frozen desserts sector ( 1.9 vs $3 \mathrm{~kg} \mathrm{CO}_{2}$ eq./£).
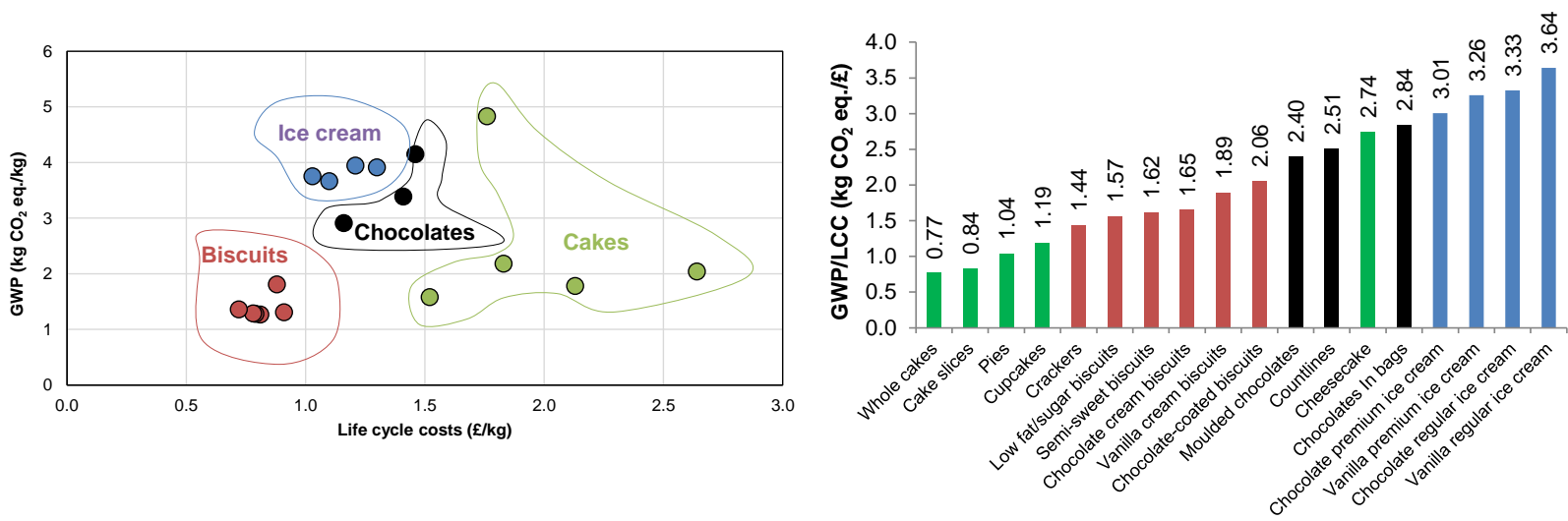

Fig. 14 Product eco-efficiency with respect to the global warming potential (GWP) and life cycle costs (left) and the ranking of products based on their eco-efficiency (right). [The values on top of the bars in the graph on the right represent the eco-efficiency scores of the products obtained by dividing their respective GWP values by their life cycle costs $\left(\mathrm{kg} \mathrm{CO}_{2}\right.$ eq./£). The lower the score, the higher the eco-efficiency.] 

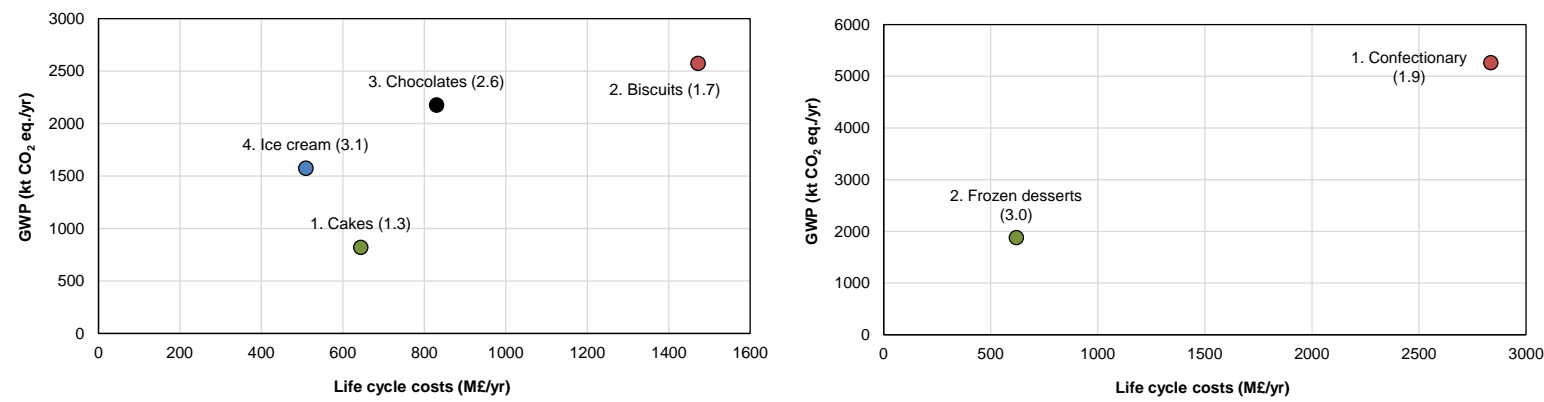

Fig. 15: Eco-efficiency at the sub-sectoral (left) and sectoral levels (right) based on the annual global warming potential (GWP) and life cycle costs. [The ordinal numbers in the graphs indicate the ranking of the sectors and the values in brackets are their respective ecoefficiency scores obtained by dividing the GWP by the LCC values $\left(\mathrm{kg} \mathrm{CO}_{2}\right.$ eq./£). The lower the score, the higher the eco-efficiency.]

\section{Conclusions}

This study has estimated life cycle costs and value added of biscuits, cakes, chocolates and ice cream, both at the level of individual products and for the whole sector. For the 18 product types assessed, the life cycle costs range from $£ 0.72$ to $£ 2.64 / \mathrm{kg}$, with vanilla cream biscuits having the lowest and whole cakes the highest costs.

In the biscuits category, crackers have the highest life cycle costs, followed by chocolatecoated; vanilla cream biscuits are the least costly. Raw materials are the main hotspot, with flour, milk and cocoa powder being the main contributors.

In the cakes sector, whole cakes have the highest costs. Like the other product categories, the majority of costs within the life cycle of cakes are related to raw materials.

Chocolates show a similar pattern in terms of the contribution analysis: raw materials production is by far the most costly stage, accounting for $89 \%-94 \%$ of the total life cycle costs. Milk powder, cocoa butter and liquor as well as sugar production are the most costrelevant activities.

Within the ice cream sector, the premium versions have up to $18 \%$ higher life cycle costs than their regular counterparts, primarily because they contain egg yolk and more sugar. Chocolate premium ice cream has the highest overall costs. The majority of costs are due to raw materials, followed by manufacturing, packaging and retail. Within these, the key activities are milk production, energy consumption for ice cream refrigeration and packaging.

The estimated value added across the products ranges from $£ 0.35 / \mathrm{kg}$ for semi-sweet biscuits to $£ 11.28 / \mathrm{kg}$ for cupcakes. Chocolates in bags, moulded chocolates, cake slices and cream biscuits also have a high value added (£5.71-6.84/kg) which is four to six times higher than their overall costs. It is also notable that premium ice cream products create four times higher value added than their regular counterparts $(\sim £ 4 / \mathrm{kg}$ vs $\sim £ 1 / \mathrm{kg})$, despite a much smaller difference in their costs (18\%).

The total annual life cycle costs in the four sectors considered are estimated at $£ 3.455$ billion, of which $42 \%$ is contributed by the biscuits due to their high sales volume. The total value added is nearly $£ 6.5$ billion per year, half of which is created by chocolates because of their high retail prices.

The study has also demonstrated how LCC can be used to evaluate the eco-efficiency of products and sectors. Using global warming potential as an environmental indicator, the results suggest that whole cakes are the most eco-efficient and vanilla regular ice cream the least efficient products. The same trend is found at the sectoral level, with cakes being the best and ice cream the worst sub-sectors for the eco-efficiency. Overall, the confectionary sector is around $60 \%$ more eco-efficient than the frozen desserts sector. However, these 
results are based on one environmental indicator so the ranking of products and sectors could change if other life cycle impacts are also taken into account. This should be considered as part of future work. Multi-criteria decision analysis could be used to rank the products and sectors on their eco-efficiency.

The results of this study can be used for benchmarking of different products and to drive innovation towards economically-sustainable and eco-efficient confectionary and frozen desserts supply chains. They can also be used to stimulate closer collaboration between different players in the supply chain, helping to make more informed procurement and purchasing decisions. Although the focus here has been on the UK market, the methods developed are generic and can be applied to estimate life cycle costs, value added, and ecoefficiency of these sectors in other countries and regions.

\section{Acknowledgements}

This research has been founded by the UK Engineering and Physical Sciences Research Council, EPSRC (Grant no. EP/K011820/1). This funding is gratefully acknowledged.

\section{References}

Bulk powders UK, 2015. Bulk powders egg prices. https://www.bulkpowders.co.uk.

Credit Chem Group, 2015. Gritting \& Salt supply. www.ngs.co.uk/.

DairyCo, 2015. AHDB dairy. https://dairy.ahdb.org.uk/.

Darrant Chemicals, 2015. High quality chemical supplies. http://darrantchemicals.co.uk/.

DECC, 2015. Department of Energy and Climate Change.

https://www.gov.uk/government/collections/quarterly-energy-prices.

DEFRA, 2015. Commodity prices. https://www.gov.uk/government/statistical-datasets/commodity-prices.

FAO, 2015. Food and Agriculture Organization of the United Nations. www.fao.org.

Fine Food Specialist, 2015. The food specialist. https://www.finefoodspecialist.co.uk/.

Global Petrol Prices, 2014. Fuel prices. http://www.globalpetrolprices.com/.

Hunkeler, D., Lichtenvort, K. \& Rebitzer, G., 2007. Environmental life cycle costing. 1st ed. London: SETAC Europe.

ICIS, 2015. Acetic acid prices. https://www.icis.com/chemicals/acetic-acid/.

Index Mundi, $2015 . \quad$ Index Mundi commodity prices. http://www.indexmundi.com/commodities/.

ISO, 2012. Environmental management-Eco-efficiency assessment of product systemsPrinciples, requirements and guidelines ISO (14045:2012). 2nd ed. Brussels: International Organization for Standardization.

Key Note, 2015a. Biscuits \& cakes market report 2015, Richmond Upon Thames: Key Note.

Key Note, 2015b. Confectionary market report 2015, Richmond Upon Thames: Key Note.

Key Note, 2015c. Ice creams \& frozen desserts market report 2015, Richmond Upon Thames: Key Note.

Konstantas, A., 2018. Towards eco-efficient food supply chains: environmental and economic life cycle sustainability of confectionary and frozen desserts. PhD thesis, University of Manchester.

Konstantas, A., Jeswani, H. K., Stamford, L. \& Azapagic, A., 2018. Environmental impacts of chocolate production and consumption in the UK. Food Research International, Volume 106, p. 1012-1025.

Konstantas, A., L. Stamford and A. Azapagic (2019). Environmental impacts of ice cream. Journal of Cleaner Production, Volume 209, p. 259-272.

Laso, J. et al., 2018. Finding an economic and environmental balance in value chains based on circular economy thinking: An eco-efficiency methodology applied to the fish canning industry. Resources, Conservation and Recycling, Volume 133, p. 428-437.

Lehni, M., 2000. Eco - efficiency creating more value with less impact, North Yorkshire, UK: World Business Council for Sustainable Development.

LetsRecycle, 2015. LetsRecycle resource revolution. https://www.letsrecycle.com/.

LME, 2015. London Metal Exchange. https://www.Ime.com/. 
Marrieage's Master Millers, 2015. The master millers. www.marriagesmillers.co.uk/.

Morrison, 2015. Groceries.

https://groceries.morrisons.com/webshop/startWebshop.do?dnr=y.

Nguyen, T. L., Hermansen, J. E. \& Mogensen, L., 2012. Environmental costs of meat production: The case of typical EU pork production. Journal of Cleaner Production, Volume 28, p. 168-176.

Niagara Atlantic Industries, 2015. Cocoa prices. https://www.niagara-atlantic.com/price-listcocoa.

Office for National Statistics, 2015. Fruit and vegetable prices. https://www.gov.uk/government/statistical-data-sets/wholesale-fruit-and-vegetable-pricesweekly-average.

Ofgem, 2015. Domestic Electricity. https://www.ofgem.gov.uk/.

Palisade, 2017. New @RISK and decision tools. www.palisade.com.

Plastics Informat, 2015. Polymer Prices. www. plasticsinfomart.com/.

RealFoods UK, 2015. RealFoods natural shopping. https://www.realfoods.co.uk/.

Sainsbury's, 2015. Groceries. http://www.sainsburys.co.uk/.

Sanye-Mengual, E. et al., 2018. Eco-efficiency assessment and food security potential of home gardening: A cas study in Padua, Italy. Sustainability, Volume 10, p. 2124.

Schmidt Rivera, X. C. \& Azapagic, A., 2014. Life cycle costs and environmental impacts of production and consumption of ready and home-made meals. Journal of Cleaner Production, Volume 73, p. $294-309$.

Settani, E., Notarnicola, G. \& Tassielli, 2010. Application of a costing model consistent with LCA to the production of pasta in a small - sized firm. $7^{\text {th }}$ international conference on life cycle assessment in the agri-food sector. Bari, 22-24 Sept 2010.

Statista, 2018a. Sales value of confectionery in selected European countries as of fourth quarter 2015, by country (in million euros). www.statista.com.

Statista, 2018b. Sales volume of ice cream and frozen desserts in selected countries in Europe in 2015 (in thousand metric tons). www.statista.com.

Sutherland, S. \& Canwell, D., 2004. Key concepts in accounting and finance. s.I.:Macmillan.

Technicold Services, 2015. Ammonia the alternative refrigerant. www.retaaz.com/retaazphx/gcb/717.htm.

Tesco, 2015. Groceries. https://www.tesco.com/.

The World Bank, 2010. https://www.worldbank.org/.

United Utilities, 2015. Water Prices. https://www.unitedutilities.com/.

Vanilla Mart, 2015. Vanilla Mart. http://vanillamart.co.uk.

VVT, 2010. Examples on vehicle performance: fuel consumption and emissions. www.nvfnorden.org/.

WRAP, 2015. Circular economy \& resource efficiency experts. http://wrap.org.uk/. 
Economic sustainability of food supply chains: life cycle costs and value added in the confectionary and frozen desserts sectors

Antonios Konstantas, Laurence Stamford and Adisa Azapagic

\section{Supporting information}

Table S1a. Estimates of the volume of biscuits sold annually

\begin{tabular}{|c|c|c|c|c|c|c|}
\hline $\begin{array}{l}\text { 1.Sales volume (Key } \\
\text { Note 2015a) }\end{array}$ & $\begin{array}{l}\text { 2. Biscuit categories - } \\
\text { consumer perspective }\end{array}$ & $\begin{array}{l}\text { 3. Biscuits } \\
\text { categories - } \\
\text { manufacturer } \\
\text { perspective }\end{array}$ & $\begin{array}{l}\text { 4. Alignment of } \\
\text { consumer and } \\
\text { manufacturer } \\
\text { classification }\end{array}$ & 5. Assumptions & $\begin{array}{l}\text { 6. Average market } \\
\text { prices }\end{array}$ & $\begin{array}{l}\text { 7. Estimated total } \\
\text { sales volume }\end{array}$ \\
\hline $\begin{array}{l}\text { Crackers: } \\
£ 362 \text { million/yr }\end{array}$ & Crackers & & $\begin{array}{l}\text { Similar from both } \\
\text { perspectives }\end{array}$ & & Crackers: $£ 1.3 / \mathrm{kg}$ & Crackers: 278,462 t \\
\hline $\begin{array}{l}\text { Healthier biscuits: } £ 612 \\
\mathrm{~m} / \mathrm{yr}\end{array}$ & Healthier biscuits & Low fat/sugar & $\begin{array}{l}\text { Healthier biscuits equal } \\
\text { low fat/sugar }\end{array}$ & & Low fat/sugar: $£ 1.5 / \mathrm{kg}$ & Low fat/sugar: $408,000 \mathrm{t}$ \\
\hline $\begin{array}{l}\text { Chocolate biscuits: } \\
£ 417 \mathrm{~m} / \mathrm{yr}\end{array}$ & Chocolate biscuits & $\begin{array}{l}\text { Chocolate- } \\
\text { coated/chocolate } \\
\text { cream }\end{array}$ & $\begin{array}{l}\text { Chocolate biscuits equal } \\
\text { chocolate-coated plus } \\
\text { chocolate cream sandwich }\end{array}$ & & & \\
\hline \multirow[t]{4}{*}{$\begin{array}{l}\text { Everyday biscuits: £563 } \\
\mathrm{m} / \mathrm{yr}\end{array}$} & Everyday biscuits & Semi-sweet & $\begin{array}{l}\text { Everyday biscuits equal } \\
\text { semi-sweet plus vanilla } \\
\text { cream sandwich }\end{array}$ & $\begin{array}{l}\text { Equal share of } \\
\text { vanilla cream and } \\
\text { semi-sweet biscuits }\end{array}$ & Semi-sweet: $£ 1.1 / \mathrm{kg}$ & Semi-sweet: 255,909 t \\
\hline & & Chocolate-coated & $\begin{array}{l}\text { Chocolate biscuits equal } \\
\text { chocolate-coated plus } \\
\text { chocolate cream sandwich }\end{array}$ & $\begin{array}{l}\text { Equal share of } \\
\text { chocolate-coated } \\
\text { and chocolate } \\
\text { cream biscuits }\end{array}$ & Chocolate-coated: £2/kg & $\begin{array}{l}\text { Chocolate-coated: } \\
104,250 \mathrm{t}\end{array}$ \\
\hline & & $\begin{array}{l}\text { Chocolate cream } \\
\text { sandwich }\end{array}$ & $\begin{array}{l}\text { Chocolate biscuits equal } \\
\text { chocolate-coated plus } \\
\text { chocolate cream sandwich }\end{array}$ & $\begin{array}{l}\text { Equal share of } \\
\text { chocolate-coated } \\
\text { and chocolate } \\
\text { cream biscuits }\end{array}$ & $\begin{array}{l}\text { Chocolate cream: } \\
£ 6.5 / \mathrm{kg}\end{array}$ & $\begin{array}{l}\text { Chocolate cream: } \\
32,077 \mathrm{t}\end{array}$ \\
\hline & & $\begin{array}{l}\text { Vanilla cream } \\
\text { sandwich }\end{array}$ & $\begin{array}{l}\text { Everyday biscuits equal } \\
\text { semi-sweet plus vanilla } \\
\text { cream sandwich }\end{array}$ & $\begin{array}{l}\text { Equal share of } \\
\text { vanilla cream and } \\
\text { semi-sweet biscuits }\end{array}$ & Vanilla cream: $£ 6.4 / \mathrm{kg}$ & Vanilla cream: 43,984 t \\
\hline $\begin{array}{l}\text { Other types (seasonal, } \\
\text { special, children’s, } \\
\text { etc.): £563 m/yr } \\
\text { Total: } £ 2,608 \mathrm{~m} / \mathrm{yr}\end{array}$ & Other types & Other types & $\begin{array}{l}\text { Similar from both } \\
\text { perspectives }\end{array}$ & & Other: $£ 1.1 / \mathrm{kg}$ & Other: 594,545 t \\
\hline
\end{tabular}


Table S1b. Estimates of the volume of cakes sold annually

\begin{tabular}{|c|c|c|c|}
\hline 1. Sales volume (Key Note 2015a \& c) & 2. Assumptions & 3. Average market prices & 4. Estimated total sales volume \\
\hline $\begin{array}{l}\text { Whole cakes: } £ 287 \text { million/yr } \\
\text { Individual cakes: } 1,087 \mathrm{~m} / \mathrm{yr}\end{array}$ & Assumed to be Victoria sponge cake & Whole cakes: $£ 6.8 / \mathrm{kg}$ & Whole cakes: $42,206 \mathrm{t}$ \\
\hline $\begin{array}{l}\text { Cake slices: } £ 362.3 \mathrm{~m} / \mathrm{yr} \\
\text { Pies: £362.3 m/yr } \\
\text { Cupcakes: } £ 362.3 \mathrm{~m} / \mathrm{yr} \\
\text { Cheesecake:£272 m/yr } \\
\text { Total: } 1,645.9 \mathrm{~m} / \mathrm{yr}\end{array}$ & Equal share of slices, pies and cupcakes & $\begin{array}{l}\text { Cake slices: } £ 8 / \mathrm{kg} \\
\text { Pies: } 2 / \mathrm{kg} \\
\text { Cupcakes: } 2 / \mathrm{kg} \\
\text { Cheesecake: } £ 4.3 / \mathrm{kg} \text {. }\end{array}$ & $\begin{array}{l}\text { Cake slices: } 45,288 \mathrm{t} \\
\text { Pies: } 181,150 \mathrm{t} \\
\text { Cupcakes: } 27,869 \mathrm{t} \\
\text { Cheesecake: } 63,256 \mathrm{t} \text {. }\end{array}$ \\
\hline
\end{tabular}

Table S1c. Estimates of the volume of chocolates sold annually

\begin{tabular}{llll}
\hline 1.Sales volume (Key Note 2015b) & $\begin{array}{l}\text { 2. Chocolates categories - } \\
\text { consumer perspective }\end{array}$ & $\begin{array}{l}\text { 3. Chocolate categories - } \\
\text { manufacturer perspective }\end{array}$ & $\begin{array}{l}\text { 4. Average market prices } \\
\text { sales volume }\end{array}$ \\
\hline Moulded chocolates: $£ 845 \mathrm{million} / \mathrm{yr}$ & Moulded chocolates & Moulded chocolates & Moulded: $£ 7.5 / \mathrm{kg}$ \\
Chocolate countlines: $£ 1,817 \mathrm{~m} / \mathrm{yr}$ & Chocolate countlines & Chocolate countlines & Countlines: $£ 6 / \mathrm{kg}$ \\
Chocolates in bag: $£ 1,304 \mathrm{~m} / \mathrm{yr}$ & Chocolates in bag & Chocolates in bag & In bag: $£ 8.3 / \mathrm{kg}$ \\
Other chocolates: $£ 378 \mathrm{~m} / \mathrm{yr}$ & Other chocolates & Other chocolates & Other: $£ 6 / \mathrm{kg}$ \\
Total: $4,344 \mathrm{~m} / \mathrm{yr}$ & & & \\
\hline
\end{tabular}

Table S1d. Estimates of the volume of ice cream sold annually

\begin{tabular}{|c|c|c|c|c|c|}
\hline $\begin{array}{l}\text { 1. Sales volume (Key } \\
\text { Note 2015c) }\end{array}$ & $\begin{array}{l}\text { 2. Sales share in the take- } \\
\text { home sector }\end{array}$ & $\begin{array}{l}\text { 3. Product categories } \\
\text { considered }\end{array}$ & 4. Assumptions & $\begin{array}{l}\text { 5. Average market } \\
\text { prices }\end{array}$ & $\begin{array}{l}\text { 6. Estimated total sales } \\
\text { volume }\end{array}$ \\
\hline \multirow[t]{2}{*}{$\begin{array}{l}\text { Take-home ice cream: } \\
£ 899 \text { million/yr }\end{array}$} & Regular ice cream $12.2 \%$ & Regular ice cream & $\begin{array}{l}\text { Vanilla and chocolate occupy } \\
100 \% \text { of the regular and } \\
\text { premium ice cream market in } \\
\text { equal shares (no actual data } \\
\text { available) }\end{array}$ & Regular: £2/kg & $\begin{array}{l}\text { Vanilla regular: } 27,500 \mathrm{t} \\
\text { Chocolate regular: } 27,500 \mathrm{t}\end{array}$ \\
\hline & Premium ice cream $49.3 \%$ & Premium ice cream & & Premium: $£ 5 / k g$ & $\begin{array}{l}\text { Vanilla premium: } 44,300 \mathrm{t} \\
\text { Chocolate premium: } 44,300 \mathrm{t}\end{array}$ \\
\hline $\begin{array}{l}\text { Wrapped impulse ice } \\
\text { cream: } £ 234 \mathrm{~m} / \mathrm{yr}\end{array}$ & Multipacks $38.5 \%$ & $\begin{array}{l}\text { Other (wrapped } \\
\text { impulse\& multipacks) }\end{array}$ & & $\begin{array}{l}\text { Other (wrapped } \\
\text { impulse \& } \\
\text { multipacks) } \\
£ 2.225 / \mathrm{kg}\end{array}$ & Other ice cream: $260,674 \mathrm{t}$ \\
\hline Total: $1,133 \mathrm{~m} / \mathrm{yr}$ & & & & & \\
\hline
\end{tabular}


Table S2: Life cycle cost inventory for the 18 products considered in the study

\begin{tabular}{|c|c|c|c|c|c|}
\hline Crackers & Activities & $\begin{array}{l}\text { Value per functional unit } \\
\text { (1 kg of product) }\end{array}$ & Unit & Unit price $(£)$ & Total cost $(£)$ \\
\hline Raw materials (RM) & Flour white & 0.653 & $\mathrm{~kg}$ & 0.936 & 0.611208 \\
\hline $\mathrm{RM}$ & Palm oil & 0.103 & $\mathrm{~kg}$ & 0.3698 & 0.0380894 \\
\hline $\mathrm{RM}$ & Sugar & 0.0115 & $\mathrm{~kg}$ & 0.37 & 0.004255 \\
\hline $\mathrm{RM}$ & Ammonium bicarbonate & 0.0013 & $\mathrm{~kg}$ & 0.33 & 0.000429 \\
\hline $\mathrm{RM}$ & Salt & 0.0064 & $\mathrm{~kg}$ & 0.13 & 0.000832 \\
\hline $\mathrm{RM}$ & Yeast & 0.0064 & $\mathrm{~kg}$ & 9.36 & 0.059904 \\
\hline $\mathrm{RM}$ & Water & 0.28 & $\mathrm{~kg}$ & 0.0016 & 0.000448 \\
\hline Transport (TR) & Transport lorry (raw materials to manufacturer) & 184.48 & $\mathrm{~kg}^{*} \mathrm{~km}$ & 0.00003 & 0.0055344 \\
\hline TR & Transport ship (raw materials to manufacturer & 1630 & $\mathrm{~kg}^{*} \mathrm{~km}$ & $5.00 \mathrm{E}-08$ & 0.0000815 \\
\hline Manufacturing (MA) & Electricity & 1.259 & MJ & 0.022 & 0.027698 \\
\hline MA & Gas & 4.16 & MJ & 0.0054 & 0.022464 \\
\hline MA & Lubricants & 0.00001 & $\mathrm{~kg}$ & 0.664 & 0.00000664 \\
\hline MA & Wastewater & 0.5 & $\mathrm{~L}$ & 0.0013 & 0.00065 \\
\hline MA & Water & 0.5 & $\mathrm{~L}$ & 0.0016 & 0.0008 \\
\hline Packaging (PA) & Polypropylene primary packaging & 0.0104 & $\mathrm{~kg}$ & 1.69 & 0.017576 \\
\hline $\mathrm{PA}$ & Cardboard secondary packaging & 0.382 & $\mathrm{~kg}$ & 0.14 & 0.05348 \\
\hline $\begin{array}{l}\text { TR } \\
\text { Distribution centre }\end{array}$ & Transport lorry & 7.29 & $\mathrm{~kg}^{*} \mathrm{~km}$ & 0.00003 & 0.0002187 \\
\hline (DC) & Water & 0.00693 & L & 0.0016 & 0.000011088 \\
\hline TR & Transport lorry & 150 & $\mathrm{~kg}^{*} \mathrm{~km}$ & 0.00003 & 0.0045 \\
\hline DC & Electricity & 0.00000205 & MJ & 0.022 & 4.51E-08 \\
\hline DC & Wastewater & 0.00693 & $\mathrm{~L}$ & 0.0013 & 0.000009009 \\
\hline DC & LDPE tertiary packaging & 0.00047 & $\mathrm{~kg}^{*} \mathrm{~km}$ & 1.57 & 0.0007379 \\
\hline TR & Transport lorry & 50 & $\mathrm{~kg}^{*} \mathrm{~km}$ & 0.00003 & 0.0015 \\
\hline PA & Plastic bags 1 bag weight $0.0075 \mathrm{~kg}$ and costs $5 p$ & 0.0047 & $\mathrm{~kg}$ & 6.6 & 0.03102 \\
\hline Retailer (RE) & Water & 2.09 & $\mathrm{~L}$ & 0.0016 & 0.003344 \\
\hline $\mathrm{RE}$ & Electricity & 0.000824 & MJ & 0.022 & 0.000018128 \\
\hline $\mathrm{RE}$ & Wastewater & 2.09 & $\mathrm{~L}$ & 0.0013 & 0.002717 \\
\hline RE & Waste to recycling (secondary packaging) & 0.033043 & $\mathrm{~kg}$ & 0.06 & 0.00198258 \\
\hline Savings (S) & Recycled corrugated board savings & -0.0297387 & $\mathrm{~kg}$ & 0.14 & -0.004163418 \\
\hline RE & Waste to landfill (secondary packaging) & 0.005157 & $\mathrm{~kg}$ & 0.1 & 0.0005157 \\
\hline $\mathrm{RE}$ & Waste to energy (tertiary packaging) & -0.03207654 & MJ & 0.022 & -0.000705684 \\
\hline $\mathrm{RE}$ & Waste to landfill (tertiary packaging) & 0.00047 & $\mathrm{~kg}$ & 0.99 & 0.0004653 \\
\hline S & Energy from thermal treatment & -0.0106596 & MJ & 0.022 & -0.000234511 \\
\hline TR & Passenger car & 0.135 & $\mathrm{~km}$ & 0.12 & 0.0162 \\
\hline
\end{tabular}


Table S2: continued

\begin{tabular}{|c|c|c|c|c|c|}
\hline Crackers & Activities & $\begin{array}{r}\text { Value per functional unit } \\
(1 \mathrm{~kg} \text { of product) }\end{array}$ & Unit & Unit price $(£)$ & Total cost $(£)$ \\
\hline Consumer (CO) & Waste to landfill [plastic bags] & 0.002726 & $\mathrm{~kg}$ & 0.1 & 0.0002726 \\
\hline $\mathrm{CO}$ & Waste to thermal treatment (plastic bags) & 0.001974 & $\mathrm{~kg}$ & 0.99 & 0.00195426 \\
\hline S & Energy from thermal treatment & -0.03624264 & MJ & 0.022 & -0.000797338 \\
\hline End of life (EOL) & Waste to thermal treatment (primary packaging) & 0.004368 & $\mathrm{~kg}$ & 0.99 & 0.00432432 \\
\hline EOL & Waste to landfill (primary packaging) & 0.006032 & $\mathrm{~kg}$ & 0.1 & 0.0006032 \\
\hline $\mathrm{S}$ & Energy from thermal treatment & -0.08019648 & MJ & 0.022 & -0.001764323 \\
\hline $\begin{array}{l}\text { Low fat/sugar } \\
\text { biscuits }\end{array}$ & Activities & $\begin{array}{l}\text { Value per functional unit } \\
\text { (1 kg of product) }\end{array}$ & Unit & Unit price $(£)$ & Total cost $(£)$ \\
\hline RM & Flour white & 0.658 & $\mathrm{~kg}$ & 0.936 & 0.615888 \\
\hline $\mathrm{RM}$ & Palm oil & 0.057 & $\mathrm{~kg}$ & 0.3698 & 0.0210786 \\
\hline RM & Sugar & 0.105 & $\mathrm{~kg}$ & 0.37 & 0.03885 \\
\hline RM & Ammonium bicarbonate & 0.01 & $\mathrm{~kg}$ & 0.33 & 0.0033 \\
\hline RM & Salt & 0.006 & $\mathrm{~kg}$ & 0.13 & 0.00078 \\
\hline RM & Water & 0.196 & L & 0.0016 & 0.0003136 \\
\hline TR & Transport lorry [tkm] while price is in $\mathrm{kg}^{\star} \mathrm{km}$ & 163.7 & $\mathrm{~kg}^{*} \mathrm{~km}$ & 0.00003 & 0.004911 \\
\hline TR & Transport ship & 94 & $\mathrm{~kg}^{*} \mathrm{~km}$ & 5.00E-08 & 0.0000047 \\
\hline MA & Electricity & 1.259 & MJ & 0.022 & 0.027698 \\
\hline MA & Gas & 4.16 & MJ & 0.0054 & 0.022464 \\
\hline MA & Lubricants & 0.00001 & $\mathrm{~kg}$ & 0.664 & 0.00000664 \\
\hline MA & Wastewater & 0.5 & $\mathrm{~L}$ & 0.0013 & 0.00065 \\
\hline MA & Water & 0.5 & $\mathrm{~L}$ & 0.0016 & 0.0008 \\
\hline PA & Polypropylene primary packaging & 0.0107 & $\mathrm{~kg}$ & 1.69 & 0.018083 \\
\hline PA & Cardboard secondary packaging & 0.0382 & $\mathrm{~kg}$ & 0.14 & 0.005348 \\
\hline TR & Transport lorry & 7.34 & $\mathrm{~kg}^{*} \mathrm{~km}$ & 0.00003 & 0.0002202 \\
\hline DC & Water & 0.00487 & $\mathrm{~L}$ & 0.0016 & 0.000007792 \\
\hline TR & Transport lorry & 150 & $\mathrm{~kg}^{*} \mathrm{~km}$ & 0.00003 & 0.0045 \\
\hline DC & Electricity & $1.44 \mathrm{E}-06$ & MJ & 0.022 & $3.168 \mathrm{E}-08$ \\
\hline DC & Wastewater & 0.00487 & $\mathrm{~L}$ & 0.0013 & 0.000006331 \\
\hline DC & LDPE tertiary packaging & 0.00047 & $\mathrm{~kg}$ & 1.57 & 0.0007379 \\
\hline TR & Transport, lorry (distribution centre to retailer) & 50 & $\mathrm{~kg}^{*} \mathrm{~km}$ & 0.00003 & 0.0015 \\
\hline PA & Plastic bags 1 bag weight $0.0075 \mathrm{~kg}$ and costs $5 p$ & 0.00325 & $\mathrm{~kg}$ & 6.6 & 0.02145 \\
\hline $\mathrm{RE}$ & Water & 1.46 & $\mathrm{~L}$ & 0.0016 & 0.002336 \\
\hline
\end{tabular}


Table S2: continued

\begin{tabular}{|c|c|c|c|c|c|}
\hline $\begin{array}{l}\text { Low fat/sugar } \\
\text { biscuits }\end{array}$ & Activities & $\begin{array}{r}\text { Value per functional unit } \\
\text { (1 kg of product) }\end{array}$ & Unit & Unit price (£) & Total cost $(£)$ \\
\hline $\mathrm{RE}$ & Electricity & 0.000576 & MJ & 0.022 & 0.000012672 \\
\hline RE & Wastewater & 1.46 & $\mathrm{~L}$ & 0.0013 & 0.001898 \\
\hline $\mathrm{RE}$ & Waste to recycling (secondary packaging) & 0.033043 & $\mathrm{~kg}$ & 0.06 & 0.00198258 \\
\hline $\begin{array}{l}\text { RE } \\
\text { S }\end{array}$ & $\begin{array}{l}\text { Waste to thermal treatment (secondary packaging) } \\
\text { Recycled corrugated board savings (secondary } \\
\text { packaging) }\end{array}$ & $\begin{array}{r}0.005157 \\
-0.0297387\end{array}$ & $\begin{array}{l}\mathrm{kg} \\
\mathrm{kg}\end{array}$ & $\begin{array}{r}0.1 \\
0.14\end{array}$ & $\begin{array}{r}0.0005157 \\
-0.004163418\end{array}$ \\
\hline S & Energy from thermal treatment (secondary packaging) & -0.20552746 & MJ & 0.022 & -0.004521604 \\
\hline RE & Waste to energy (tertiary packaging) & 0.0001974 & $\mathrm{~kg}$ & 0.99 & 0.000195426 \\
\hline RE & Waste to thermal treatment (tertiary packaging) & 0.00047 & $\mathrm{~kg}$ & 0.1 & 0.000047 \\
\hline S & Energy from thermal treatment (tertiary packaging) & -0.0106596 & MJ & 0.022 & -0.000234511 \\
\hline TR & Passenger car & 0.135 & $\mathrm{~km}$ & 0.12 & 0.0162 \\
\hline $\mathrm{CO}$ & Waste to landfill (plastic bags) & 0.001885 & $\mathrm{~kg}$ & 0.1 & 0.0001885 \\
\hline $\mathrm{CO}$ & Waste to thermal treatment (plastic bags) & 0.001365 & $\mathrm{~kg}$ & 0.99 & 0.00135135 \\
\hline S & Energy from thermal treatment (plastic bags) & -0.0250614 & MJ & 0.022 & -0.000551351 \\
\hline EOL & Waste to thermal treatment (primary packaging) & 0.004494 & $\mathrm{~kg}$ & 0.99 & 0.00444906 \\
\hline EOL & Waste to landfill (primary packaging) & 0.006206 & $\mathrm{~kg}$ & 0.1 & 0.0006206 \\
\hline $\mathrm{S}$ & Energy from thermal treatment (primary packaging) & -0.08250984 & MJ & 0.022 & -0.001815216 \\
\hline $\begin{array}{l}\text { Semi-sweet } \\
\text { Biscuits }\end{array}$ & Activities & $\begin{array}{l}\text { Value per functional unit } \\
\text { ( } 1 \mathrm{~kg} \text { of product) }\end{array}$ & Unit & Unit price $(£)$ & Total cost $(£)$ \\
\hline RM & Flour white & 0.588 & $\mathrm{~kg}$ & 0.936 & 0.550368 \\
\hline $\mathrm{RM}$ & Palm oil & 0.117 & $\mathrm{~kg}$ & 0.3698 & 0.0432666 \\
\hline $\mathrm{RM}$ & Sugar & 0.161 & $\mathrm{~kg}$ & 0.37 & 0.05957 \\
\hline $\mathrm{RM}$ & Ammonium bicarbonate & 0.0008 & $\mathrm{~kg}$ & 0.33 & 0.000264 \\
\hline $\mathrm{RM}$ & Salt & 0.006 & $\mathrm{~kg}$ & 0.13 & 0.00078 \\
\hline $\mathrm{RM}$ & Water & 0.136 & L & 0.0016 & 0.0002176 \\
\hline TR & Transport lorry (raw materials to manufacturer) & 179.3 & $\mathrm{~kg}^{*} \mathrm{~km}$ & 0.00003 & 0.005379 \\
\hline TR & Transport ship (raw materials to manufacturer) & 1860 & $\mathrm{~kg}^{*} \mathrm{~km}$ & $5.00 \mathrm{E}-08$ & 0.000093 \\
\hline MA & Electricity & 1.259 & MJ & 0.022 & 0.027698 \\
\hline MA & Gas & 4.16 & MJ & 0.0054 & 0.022464 \\
\hline MA & Lubricants & 0.00001 & $\mathrm{~kg}$ & 0.664 & 0.00000664 \\
\hline MA & Wastewater & 0.5 & $\mathrm{~L}$ & 0.0013 & 0.00065 \\
\hline MA & Water & 0.5 & $\mathrm{~L}$ & 0.0016 & 0.0008 \\
\hline PA & Polypropylene primary packaging & 0.0107 & $\mathrm{~kg}$ & 1.69 & 0.018083 \\
\hline
\end{tabular}


Table S2: continued

\begin{tabular}{|c|c|c|c|c|c|}
\hline $\begin{array}{l}\text { Semi-sweet } \\
\text { Biscuits }\end{array}$ & Activities & $\begin{array}{r}\text { Value per functional unit } \\
(1 \mathrm{~kg} \text { of product) }\end{array}$ & Unit & Unit price $(£)$ & Total cost $(£)$ \\
\hline PA & Cardboard secondary packaging & 0.0382 & $\mathrm{~kg}$ & 0.14 & 0.005348 \\
\hline TR & Transport, lorry (packaging to manufacturer) & 7.34 & $\mathrm{~kg}^{*} \mathrm{~km}$ & 0.00003 & 0.0002202 \\
\hline DC & Water & 0.00487 & $\mathrm{~L}$ & 0.0016 & 0.000007792 \\
\hline TR & Transport lorry (manufacturer to distribution centre) & 150 & $\mathrm{~kg}^{*} \mathrm{~km}$ & 0.00003 & 0.0045 \\
\hline DC & Electricity & 0.00000144 & MJ & 0.022 & 3.168E-08 \\
\hline DC & Wastewater & 0.00487 & $\mathrm{~L}$ & 0.0013 & 0.000006331 \\
\hline DC & LDPE film (tertiary packaging) & 0.00047 & $\mathrm{~kg}$ & 1.57 & 0.0007379 \\
\hline TR & Transport, lorry (packaging to distribution centre) & 0.0705 & $\mathrm{~kg}^{*} \mathrm{~km}$ & 0.00003 & 0.000002115 \\
\hline PA & Plastic bags ( 1 bag weighs $7.5 \mathrm{~g}$ and costs $5 p$ ) & 0.00325 & $\mathrm{~kg}$ & 6.6 & 0.02145 \\
\hline $\mathrm{RE}$ & Water & 1.46 & $\mathrm{~L}$ & 0.0016 & 0.002336 \\
\hline RE & Electricity & 0.000576 & MJ & 0.022 & 0.000012672 \\
\hline RE & Wastewater & 1.46 & L & 0.0013 & 0.001898 \\
\hline TR & Transport, lorry (distribution centre to retailer) & 50 & $\mathrm{~kg}^{*} \mathrm{~km}$ & 0.00003 & 0.0015 \\
\hline $\mathrm{RE}$ & Waste to recycling (secondary packaging) & 0.033043 & $\mathrm{~kg}$ & 0.06 & 0.00198258 \\
\hline S & Recycled corrugated board savings & -0.0297387 & $\mathrm{~kg}$ & 0.14 & -0.004163418 \\
\hline RE & Waste to landfill (secondary packaging) & 0.005157 & $\mathrm{~kg}$ & 0.1 & 0.0005157 \\
\hline S & Energy from thermal treatment (secondary packaging) & -0.03207654 & MJ & 0.022 & -0.000705684 \\
\hline RE & Waste to energy (tertiary packaging) & 0.00047 & $\mathrm{~kg}$ & 0.99 & 0.0004653 \\
\hline S & Energy from thermal treatment (tertiary packaging) & -0.0106596 & MJ & 0.022 & -0.000234511 \\
\hline TR & Passenger car & 0.135 & $\mathrm{~km}$ & 0.12 & 0.0162 \\
\hline $\mathrm{CO}$ & Waste to landfill (plastic bags) & 0.001885 & $\mathrm{~kg}$ & 0.1 & 0.0001885 \\
\hline $\mathrm{CO}$ & Waste to thermal treatment (plastic bags) & 0.001365 & $\mathrm{~kg}$ & 0.99 & 0.00135135 \\
\hline S & Energy from thermal treatment (plastic bags) & -0.0250614 & MJ & 0.022 & -0.000551351 \\
\hline EOL & Waste to thermal treatment (primary packaging) & 0.004494 & $\mathrm{~kg}$ & 0.99 & 0.00444906 \\
\hline EOL & Waste to landfill (primary packaging) & 0.006206 & $\mathrm{~kg}$ & 0.1 & 0.0006206 \\
\hline S & Energy from thermal treatment (primary packaging) & -0.08250984 & MJ & 0.022 & -0.001815216 \\
\hline $\begin{array}{l}\text { Chocolate- } \\
\text { coated } \\
\text { biscuits }\end{array}$ & Activities & $\begin{array}{l}\text { Value per functional unit } \\
\text { ( } 1 \mathrm{~kg} \text { of product) }\end{array}$ & Unit & Unit price $(£)$ & Total cost $(£)$ \\
\hline RM & Flour white & 0.3431 & $\mathrm{~kg}$ & 0.936 & 0.3211416 \\
\hline $\mathrm{RM}$ & Flour wholemeal & 0.0803 & $\mathrm{~kg}$ & 1 & 0.0803 \\
\hline $\mathrm{RM}$ & Palm oil & 0.146 & $\mathrm{~kg}$ & 0.3698 & 0.0539908 \\
\hline $\mathrm{RM}$ & Sugar & 0.1022 & $\mathrm{~kg}$ & 0.37 & 0.037814 \\
\hline $\mathrm{RM}$ & Ammonium bicarbonate & 0.0146 & $\mathrm{~kg}$ & 0.33 & 0.004818 \\
\hline
\end{tabular}


Table S2: continued

\begin{tabular}{|c|c|c|c|c|c|}
\hline $\begin{array}{l}\text { Chocolate- } \\
\text { coated } \\
\text { biscuits }\end{array}$ & Activities & $\begin{array}{r}\text { Value per functional unit } \\
\text { ( } 1 \mathrm{~kg} \text { of product) }\end{array}$ & Unit & Unit price $(£)$ & Total cost $(£)$ \\
\hline RM & Salt & 0.0073 & $\mathrm{~kg}$ & 0.13 & 0.000949 \\
\hline RM & Water & 0.028032 & L & 0.0016 & 4.48512E-05 \\
\hline TR & Transport lorry (raw materials to manufacturer) & 162.06 & $\mathrm{~kg}^{*} \mathrm{~km}$ & 0.00003 & 0.0048618 \\
\hline TR & Transport ship (raw materials to manufacturer) & 2314.1 & $\mathrm{~kg}^{*} \mathrm{~km}$ & 0.00000005 & 0.000115705 \\
\hline RM & Sugar & 0.1242 & $\mathrm{~kg}$ & 0.3698 & 0.04592916 \\
\hline RM & Cocoa powder & 0.0135 & $\mathrm{~kg}$ & 2.8471 & 0.03843585 \\
\hline RM & Palm kernel oil & 0.0783 & $\mathrm{~kg}$ & 0.595 & 0.0465885 \\
\hline $\mathrm{RM}$ & Milk powder & 0.054 & $\mathrm{~kg}$ & 2.185 & 0.11799 \\
\hline TR & Transport lorry (raw materials to manufacturer) & 56.7 & $\mathrm{~kg}^{*} \mathrm{~km}$ & 0.00003 & 0.001701 \\
\hline TR & Transport ship (raw materials to manufacturer) & 99.63 & $\mathrm{~kg}^{*} \mathrm{~km}$ & 0.00000005 & $4.9815 \mathrm{E}-06$ \\
\hline MA & Electricity & 2.136 & MJ & 0.022 & 0.046992 \\
\hline MA & Gas & 3.04 & MJ & 0.0054 & 0.016416 \\
\hline MA & Lubricants & 0.0000073 & $\mathrm{~kg}$ & 0.664 & $4.8472 \mathrm{E}-06$ \\
\hline MA & Wastewater & 0.365 & $\mathrm{~L}$ & 0.0013 & 0.0004745 \\
\hline MA & Water & 0.365 & $\mathrm{~L}$ & 0.0016 & 0.000584 \\
\hline PA & Polypropylene primary packaging & 0.0081 & $\mathrm{~kg}$ & 1.69 & 0.013689 \\
\hline PA & Cardboard secondary packaging & 0.0382 & $\mathrm{~kg}$ & 0.14 & 0.005348 \\
\hline TR & Transport lorry (packaging to manufacturer) & 6.95 & $\mathrm{~kg}^{*} \mathrm{~km}$ & 0.00003 & 0.0002085 \\
\hline DC & Water & 0.00318 & $\mathrm{~L}$ & 0.0016 & 0.000005088 \\
\hline TR & Transport lorry (manufacturer to distribution centre) & 150 & $\mathrm{~kg}^{*} \mathrm{~km}$ & 0.00003 & 0.0045 \\
\hline DC & Electricity & 0.000000942 & MJ & 0.022 & 2.0724E-08 \\
\hline DC & Wastewater & 0.00318 & $\mathrm{~L}$ & 0.0013 & 0.000004134 \\
\hline DC & LDPE tertiary packaging & 0.00047 & $\mathrm{~kg}$ & 1.57 & 0.0007379 \\
\hline TR & Transport lorry (packaging to distribution centre) & 0.0705 & $\mathrm{~kg}^{*} \mathrm{~km}$ & 0.00003 & 0.000002115 \\
\hline PA & Plastic bags 1 bag weight $0.0075 \mathrm{~kg}$ and costs $5 p$ & 0.00213 & $\mathrm{~kg}$ & 6.6 & 0.014058 \\
\hline RE & Water & 0.955 & $\mathrm{~L}$ & 0.0016 & 0.001528 \\
\hline RE & Electricity & 0.000377 & MJ & 0.022 & 0.000008294 \\
\hline RE & Wastewater & 0.955 & L & 0.0013 & 0.0012415 \\
\hline TR & Transport lorry (distribution centre to retailer) & 50 & $\mathrm{~kg}^{*} \mathrm{~km}$ & 0.00003 & 0.0015 \\
\hline RE & Waste to recycling (secondary packaging) & 0.033043 & $\mathrm{~kg}$ & 0.06 & 0.00198258 \\
\hline S & Recycled corrugated board savings & -0.0297387 & MJ & 0.14 & -0.004163418 \\
\hline RE & Waste to landfill (secondary packaging) & 0.005157 & $\mathrm{~kg}$ & 0.1 & 0.0005157 \\
\hline RE & Waste to energy (tertiary packaging) & -0.03207654 & $\mathrm{~kg}$ & 0.0793 & -0.00254367 \\
\hline RE & Waste to landfill (tertiary packaging) & 0.00047 & $\mathrm{~kg}$ & 0.99 & 0.0004653 \\
\hline S & Energy from thermal treatment (tertiary packaging) & -0.0106596 & MJ & 0.022 & -0.000234511 \\
\hline TR & Consumer's car & 0.135 & $\mathrm{~km}$ & 0.12 & 0.0162 \\
\hline
\end{tabular}


Table S2 continued

\begin{tabular}{|c|c|c|c|c|c|}
\hline $\begin{array}{l}\text { Chocolate- } \\
\text { coated } \\
\text { biscuits }\end{array}$ & Activities & $\begin{array}{r}\text { Value per functional unit } \\
\text { (1 kg of product) }\end{array}$ & Unit & Unit price (£) & Total cost $(£)$ \\
\hline $\mathrm{CO}$ & Waste to landfill (plastic bags) & 0.0012354 & $\mathrm{~kg}$ & 0.1 & 0.00012354 \\
\hline $\mathrm{CO}$ & Waste to thermal treatment (plastic bags) & 0.0008946 & $\mathrm{~kg}$ & 0.99 & 0.000885654 \\
\hline S & Energy from thermal treatment (plastic bags) & -0.016424856 & MJ & 0.022 & -0.000361347 \\
\hline EOL & Waste to thermal treatment (primary packaging) & 0.003402 & $\mathrm{~kg}$ & 0.99 & 0.00336798 \\
\hline EOL & Waste to Landfill (primary packaging) & 0.004698 & $\mathrm{~kg}$ & 0.1 & 0.0004698 \\
\hline $\mathrm{S}$ & Energy from thermal treatment (primary packaging) & -0.06246072 & MJ & 0.022 & -0.001374136 \\
\hline $\begin{array}{l}\text { Chocolate } \\
\text { cream } \\
\text { biscuits }\end{array}$ & Activities & $\begin{array}{l}\text { Value per functional unit } \\
\text { ( } 1 \mathrm{~kg} \text { of product) }\end{array}$ & Unit & Unit price (£) & Total cost $(£)$ \\
\hline RM & Flour white & 0.38908 & $\mathrm{~kg}$ & 0.936 & 0.36417888 \\
\hline RM & Palm oil & 0.08591 & $\mathrm{~kg}$ & 0.3698 & 0.031769518 \\
\hline RM & Sugar & 0.15975 & $\mathrm{~kg}$ & 0.37 & 0.0591075 \\
\hline $\mathrm{RM}$ & Ammonium bicarbonate & 0.00142 & $\mathrm{~kg}$ & 0.33 & 0.0004686 \\
\hline RM & Salt & 0.00142 & $\mathrm{~kg}$ & 0.13 & 0.0001846 \\
\hline RM & Cocoa powder & 0.01775 & $\mathrm{~kg}$ & 2.8471 & 0.050536025 \\
\hline $\mathrm{RM}$ & Water & 0.042032 & L & 0.0016 & $6.72512 \mathrm{E}-05$ \\
\hline TR & Transport lorry (raw materials to manufacturer) & 121.623 & $\mathrm{~kg}^{*} \mathrm{~km}$ & 0.00003 & 0.00364869 \\
\hline TR & Transport ship (raw materials to manufacturer) & 1363.2 & $\mathrm{~kg}^{*} \mathrm{~km}$ & $5.00 \mathrm{E}-08$ & 0.00006816 \\
\hline $\mathrm{RM}$ & Sugar & 0.1624 & $\mathrm{~kg}$ & 0.3698 & 0.06005552 \\
\hline $\mathrm{RM}$ & Cocoa powder & 0.0145 & $\mathrm{~kg}$ & 2.8471 & 0.04128295 \\
\hline RM & Palm kernel oil & 0.1102 & $\mathrm{~kg}$ & 0.595 & 0.065569 \\
\hline TR & Transport lorry (raw materials to manufacturer) & 58 & $\mathrm{~kg}$ & 0.00003 & 0.00174 \\
\hline TR & Transport ship (raw materials to manufacturer) & 1748.7 & $\mathrm{~kg}$ & $5.00 \mathrm{E}-08$ & 0.000087435 \\
\hline MA & Electricity & 1.2795 & MJ & 0.022 & 0.028149 \\
\hline MA & Gas & 2.95 & MJ & 0.0054 & 0.01593 \\
\hline MA & Lubricants & 0.0000071 & $\mathrm{~kg}$ & 0.664 & 4.7144E-06 \\
\hline MA & Wastewater & 0.355 & $\mathrm{~L}$ & 0.0013 & 0.0004615 \\
\hline MA & Water & 0.355 & $\mathrm{~L}$ & 0.0016 & 0.000568 \\
\hline PA & Polypropylene primary packaging & 0.00365 & $\mathrm{~kg}$ & 1.69 & 0.0061685 \\
\hline PA & Aluminium & 0.00365 & $\mathrm{~kg}$ & 1.22 & 0.004453 \\
\hline PA & Cardboard secondary packaging & 0.0325 & $\mathrm{~kg}$ & 0.14 & 0.00455 \\
\hline TR & Transport lorry (packaging to manufacturer) & 5.976 & $\mathrm{~kg}^{*} \mathrm{~km}$ & 0.00003 & 0.00017928 \\
\hline DC & Water & 0.00356 & $\mathrm{~L}$ & 0.0016 & 0.000005696 \\
\hline
\end{tabular}


Table S2 continued

\begin{tabular}{|c|c|c|c|c|c|}
\hline $\begin{array}{l}\text { Chocolate } \\
\text { cream } \\
\text { biscuits }\end{array}$ & Activities & $\begin{array}{r}\text { Value per functional unit } \\
\text { ( } 1 \mathrm{~kg} \text { of product) }\end{array}$ & Unit & Unit price (£) & Total cost $(£)$ \\
\hline TR & Transport lorry (manufacturer to distribution centre) & 150 & $\mathrm{~kg}^{*} \mathrm{~km}$ & 0.00003 & 0.0045 \\
\hline DC & Electricity & 0.00000105 & MJ & 0.022 & 2.31E-08 \\
\hline DC & Wastewater & 0.00356 & $\mathrm{~L}$ & 0.0013 & 0.000004628 \\
\hline DC & LDPE tertiary packaging & 0.00047 & $\mathrm{~kg}$ & 1.57 & 0.0007379 \\
\hline TR & Transport lorry (packaging to distribution centre) & 0.0705 & $\mathrm{~kg}^{*} \mathrm{~km}$ & 0.00003 & 0.000002115 \\
\hline PA & Plastic bags 1 bag weight $0.0075 \mathrm{~kg}$ and costs $5 p$ & 0.00238 & $\mathrm{~kg}$ & 6.6 & 0.015708 \\
\hline RE & Water & 1.07 & $\mathrm{~L}$ & 0.0016 & 0.001712 \\
\hline RE & Electricity & 0.000421 & MJ & 0.022 & 0.000009262 \\
\hline RE & Wastewater & 1.07 & $\mathrm{~L}$ & 0.0013 & 0.001391 \\
\hline TR & Transport lorry (distribution centre to retailer) & 50 & $\mathrm{~kg}^{*} \mathrm{~km}$ & 0.00003 & 0.0015 \\
\hline RE & Waste to recycling (secondary packaging) & 0.0281125 & $\mathrm{~kg}$ & 0.06 & 0.00168675 \\
\hline S & Recycled corrugated board savings & -0.02530125 & MJ & 0.14 & -0.003542175 \\
\hline RE & Waste to thermal treatment (secondary packaging) & 0.0043875 & $\mathrm{~kg}$ & 0.1 & 0.00043875 \\
\hline S & Energy from thermal treatment (secondary packaging] & -0.02729025 & MJ & 0.022 & -0.000600386 \\
\hline RE & Waste to energy (tertiary packaging) & 0.00047 & $\mathrm{~kg}$ & 0.99 & 0.0004653 \\
\hline S & Energy from thermal treatment (tertiary packaging) & -0.0106596 & MJ & 0.022 & -0.000234511 \\
\hline TR & Consumer's car & 0.135 & $\mathrm{~km}$ & 0.12 & 0.0162 \\
\hline $\mathrm{CO}$ & Waste to landfill (plastic bags) & 0.0013804 & $\mathrm{~kg}$ & 0.1 & 0.00013804 \\
\hline $\mathrm{CO}$ & Waste to thermal treatment (plastic bags) & 0.0009996 & $\mathrm{~kg}$ & 0.99 & 0.000989604 \\
\hline S & Energy from thermal treatment (plastic bags) & -0.018352656 & MJ & 0.022 & -0.000403758 \\
\hline EOL & Waste to thermal treatment (primary packaging) & 0.003066 & $\mathrm{~kg}$ & 0.99 & 0.00303534 \\
\hline EOL & Waste to Landfill (primary packaging) & 0.004234 & $\mathrm{~kg}$ & 0.1 & 0.0004234 \\
\hline S & Energy from thermal treatment (primary packaging) & -0.05629176 & MJ & 0.022 & -0.001238419 \\
\hline $\begin{array}{l}\text { Vanilla cream } \\
\text { biscuits }\end{array}$ & Activities & $\begin{array}{l}\text { Value per functional unit } \\
\text { ( } 1 \mathrm{~kg} \text { of product) }\end{array}$ & Unit & Unit price (£) & Total cost $(£)$ \\
\hline $\mathrm{RM}$ & Flour white & 0.39547 & $\mathrm{~kg}$ & 0.936 & 0.37015992 \\
\hline $\mathrm{RM}$ & Palm oil & 0.14413 & $\mathrm{~kg}$ & 0.3698 & 0.053299274 \\
\hline $\mathrm{RM}$ & Sugar & 0.12993 & $\mathrm{~kg}$ & 0.37 & 0.0480741 \\
\hline $\mathrm{RM}$ & Ammonium bicarbonate & 0.00213 & $\mathrm{~kg}$ & 0.33 & 0.0007029 \\
\hline $\mathrm{RM}$ & Salt & 0.00213 & $\mathrm{~kg}$ & 0.13 & 0.0002769 \\
\hline $\mathrm{RM}$ & Water & 0.031879 & L & 0.0016 & 5.10064E-05 \\
\hline TR & Transport lorry (raw materials to manufacturer) & 152.082 & $\mathrm{~kg}^{*} \mathrm{~km}$ & 0.00003 & 0.00456246 \\
\hline
\end{tabular}


Table S2 continued

\begin{tabular}{|c|c|c|c|c|c|}
\hline $\begin{array}{l}\text { Vanilla cream } \\
\text { biscuits }\end{array}$ & Activities & $\begin{array}{r}\text { Value per functional unit } \\
\text { ( } 1 \mathrm{~kg} \text { of product) }\end{array}$ & Unit & Unit price $(£)$ & Total cost $(£)$ \\
\hline TR & Transport ship (raw materials to manufacturer) & 2286.2 & $\mathrm{~kg}^{*} \mathrm{~km}$ & $5.00 \mathrm{E}-08$ & 0.00011431 \\
\hline $\mathrm{RM}$ & Sugar & 0.19053 & $\mathrm{~kg}$ & 0.3698 & 0.070457994 \\
\hline $\mathrm{RM}$ & Vanilla flavour & 0.00058 & $\mathrm{~kg}$ & 11.97 & 0.0069426 \\
\hline $\mathrm{RM}$ & Palm oil & 0.08671 & $\mathrm{~kg}$ & 0.3698 & 0.032065358 \\
\hline $\mathrm{RM}$ & Milk powder & 0.01218 & $\mathrm{~kg}$ & 2.185 & 0.0266133 \\
\hline TR & Transport lorry (raw materials to manufacturer) & 2.436 & $\mathrm{~kg}^{*} \mathrm{~km}$ & 0.00003 & 0.00007308 \\
\hline TR & Transport ship (raw materials to manufacturer) & 1374.6 & $\mathrm{~kg}^{*} \mathrm{~km}$ & $5.00 \mathrm{E}-08$ & 0.00006873 \\
\hline MA & Electricity & 1.2795 & MJ & 0.022 & 0.028149 \\
\hline MA & Gas & 2.95 & MJ & 0.0054 & 0.01593 \\
\hline MA & Lubricants & 0.0000071 & $\mathrm{~kg}$ & 0.664 & 4.7144E-06 \\
\hline MA & Wastewater & 0.355 & $\mathrm{~L}$ & 0.0013 & 0.0004615 \\
\hline MA & Water & 0.355 & $\mathrm{~L}$ & 0.0016 & 0.000568 \\
\hline PA & Polypropylene primary packaging & 0.00365 & $\mathrm{~kg}$ & 1.69 & 0.0061685 \\
\hline PA & Aluminium & 0.00365 & $\mathrm{~kg}$ & 1.22 & 0.004453 \\
\hline PA & Cardboard secondary packaging & 0.0325 & $\mathrm{~kg}$ & 0.14 & 0.00455 \\
\hline TR & Transport lorry (packaging to manufacturer) & 5.976 & $\mathrm{~kg}^{*} \mathrm{~km}$ & 0.00003 & 0.00017928 \\
\hline DC & Water & 0.00356 & L & 0.0016 & 0.000005696 \\
\hline TR & Transport lorry (manufacturer to distribution centre) & 150 & $\mathrm{~kg}^{*} \mathrm{~km}$ & 0.00003 & 0.0045 \\
\hline DC & Electricity & 0.00000105 & MJ & 0.022 & 2.31E-08 \\
\hline DC & Wastewater & 0.00356 & $\mathrm{~L}$ & 0.0013 & 0.000004628 \\
\hline DC & LDPE tertiary packaging & 0.00047 & $\mathrm{~kg}$ & 1.57 & 0.0007379 \\
\hline TR & Transport lorry (packaging to distribution centre) & 0.0705 & $\mathrm{~kg}^{*} \mathrm{~km}$ & 0.00003 & 0.000002115 \\
\hline PA & Plastic bags 1 bag weight $0.0075 \mathrm{~kg}$ and costs $5 p$ & 0.00238 & $\mathrm{~kg}$ & 6.6 & 0.015708 \\
\hline RE & Water & 1.07 & $\mathrm{~L}$ & 0.0016 & 0.001712 \\
\hline RE & Electricity & 0.000421 & MJ & 0.022 & 0.000009262 \\
\hline RE & Wastewater & 1.07 & L & 0.0013 & 0.001391 \\
\hline TR & Transport lorry (distribution centre to retailer) & 50 & $\mathrm{~kg}^{*} \mathrm{~km}$ & 0.00003 & 0.0015 \\
\hline $\mathrm{RE}$ & Waste to recycling (secondary packaging) & 0.0281125 & $\mathrm{~kg}$ & 0.06 & 0.00168675 \\
\hline S & Recycled corrugated board savings & -0.02530125 & MJ & 0.14 & -0.003542175 \\
\hline $\mathrm{RE}$ & Waste to thermal treatment (secondary packaging) & 0.0043875 & $\mathrm{~kg}$ & 0.1 & 0.00043875 \\
\hline S & Energy from thermal treatment (secondary packaging) & -0.02729025 & MJ & 0.022 & -0.000600386 \\
\hline $\mathrm{RE}$ & Waste to energy (tertiary packaging) & 0.00047 & $\mathrm{~kg}$ & 0.99 & 0.0004653 \\
\hline S & Energy from thermal treatment (tertiary packaging) & -0.0106596 & MJ & 0.022 & -0.000234511 \\
\hline
\end{tabular}


Table S2 continued

\begin{tabular}{|c|c|c|c|c|c|}
\hline $\begin{array}{l}\text { Vanilla cream } \\
\text { biscuits }\end{array}$ & Activities & $\begin{array}{r}\text { Value per functional unit } \\
(1 \mathrm{~kg} \text { of product) }\end{array}$ & Unit & Unit price $(£)$ & Total cost $(£)$ \\
\hline TR & Consumer's car & 0.135 & $\mathrm{~km}$ & 0.12 & 0.0162 \\
\hline $\mathrm{CO}$ & Waste to landfill (plastic bags) & 0.0013804 & $\mathrm{~kg}$ & 0.1 & 0.00013804 \\
\hline $\mathrm{CO}$ & Waste to thermal treatment (plastic bags) & 0.0009996 & $\mathrm{~kg}$ & 0.99 & 0.000989604 \\
\hline S & Energy from thermal treatment (plastic bags) & -0.018352656 & MJ & 0.022 & -0.000403758 \\
\hline EOL & Waste to thermal treatment (primary packaging) & 0.003066 & $\mathrm{~kg}$ & 0.99 & 0.00303534 \\
\hline EOL & Waste to Landfill (primary packaging) & 0.004234 & $\mathrm{~kg}$ & 0.1 & 0.0004234 \\
\hline S & Energy from thermal treatment (primary packaging) & -0.018352656 & MJ & 0.022 & -0.000403758 \\
\hline Whole cakes & Activities & $\begin{array}{c}\text { Value per functional unit } \\
(1 \mathrm{~kg} \text { of product })\end{array}$ & Unit & Unit price $(£)$ & Total cost $(£)$ \\
\hline RM & Strawberry & 0.15 & $\mathrm{~kg}$ & 2.26 & 0.339 \\
\hline TR & Transport lorry (raw materials to manufacturer) & 30 & $\mathrm{~kg}^{*} \mathrm{~km}$ & 0.00003 & 0.0009 \\
\hline RM & Vanilla flavour & 0.0027 & $\mathrm{~kg}$ & 11.97 & 0.032319 \\
\hline RM & Sugar & 0.15606 & $\mathrm{~kg}$ & 0.37 & 0.0577422 \\
\hline RM & Butter & 0.11124 & $\mathrm{~kg}$ & 1.9437 & 0.216217188 \\
\hline TR & Transport lorry (raw materials to manufacturer) & 22.788 & $\mathrm{~kg}^{*} \mathrm{~km}$ & 0.00003 & 0.00068364 \\
\hline RM & Flour white & 0.1392 & $\mathrm{~kg}$ & 0.936 & 0.1302912 \\
\hline RM & Palm oil & 0.0232 & $\mathrm{~kg}$ & 0.3698 & 0.00857936 \\
\hline RM & Sugar & 0.116 & $\mathrm{~kg}$ & 0.37 & 0.04292 \\
\hline RM & Soda & 0.0203 & $\mathrm{~kg}$ & 0.33 & 0.006699 \\
\hline RM & Salt & 0.000928 & $\mathrm{~kg}$ & 0.13 & 0.00012064 \\
\hline RM & Starch & 0.0174 & $\mathrm{~kg}$ & 1.12 & 0.019488 \\
\hline RM & Sorbic acid/sorbates & 0.001392 & $\mathrm{~kg}$ & 79.19 & 0.11023248 \\
\hline RM & Eggs pasteurised & 0.2436 & $\mathrm{~kg}$ & 5.99 & 1.459164 \\
\hline RM & Glycerine & 0.0174 & $\mathrm{~kg}$ & 2.4 & 0.04176 \\
\hline RM & Acetic acid & 0.0058 & $\mathrm{~kg}$ & 0.46 & 0.002668 \\
\hline TR & Transport lorry (raw materials to manufacturer) & 47.444 & $\mathrm{~kg}^{*} \mathrm{~km}$ & 0.00003 & 0.00142332 \\
\hline TR & Transport ship (raw materials to manufacturer) & 368.3 & $\mathrm{~kg}^{*} \mathrm{~km}$ & $5.00 \mathrm{E}-08$ & 0.000018415 \\
\hline MA & Electricity & 0.5475 & MJ & 0.022 & 0.012045 \\
\hline MA & Gas & 0.543 & MJ & 0.0054 & 0.0029322 \\
\hline MA & Steam & 0.501 & MJ & 0.034 & 0.017034 \\
\hline MA & Lubricants & 0.0000058 & $\mathrm{~kg}$ & 0.664 & 3.8512E-06 \\
\hline
\end{tabular}


Table S2 continued

\begin{tabular}{|c|c|c|c|c|c|}
\hline Whole cakes & Activities & $\begin{array}{r}\text { Value per functional unit } \\
\text { (1 kg of product) }\end{array}$ & Unit & Unit price (£) & Total cost $(£)$ \\
\hline MA & Wastewater & 0.29 & $\mathrm{~L}$ & 0.0013 & 0.000377 \\
\hline MA & Water & 0.29 & $\mathrm{~L}$ & 0.0016 & 0.000464 \\
\hline PA & Polypropylene primary packaging & 0.006 & $\mathrm{~kg}$ & 1.69 & 0.01014 \\
\hline PA & Folding box & 0.087 & $\mathrm{~kg}$ & 0.14 & 0.01218 \\
\hline PA & Cardboard secondary packaging & 0.054 & $\mathrm{~kg}$ & 0.14 & 0.00756 \\
\hline TR & Transport lorry (packaging to manufacturer) & 22.1 & $\mathrm{~kg}^{*} \mathrm{~km}$ & 0.00003 & 0.000663 \\
\hline DC & Water & 0.00636 & $\mathrm{~L}$ & 0.0016 & 0.000010176 \\
\hline TR & Transport lorry & 150 & $\mathrm{~kg}^{*} \mathrm{~km}$ & 0.00003 & 0.0045 \\
\hline DC & Electricity & 0.00000188 & MJ & 0.022 & 4.136E-08 \\
\hline DC & Wastewater & 0.00636 & $\mathrm{~L}$ & 0.0013 & 0.000008268 \\
\hline DC & LDPE tertiary packaging & 0.00047 & $\mathrm{~kg}$ & 1.57 & 0.0007379 \\
\hline TR & Transport lorry (packaging to distribution centre) & 0.0705 & $\mathrm{~kg}^{*} \mathrm{~km}$ & 0.00003 & 0.000002115 \\
\hline $\mathrm{RE}$ & Water & 1.91 & L & 0.0016 & 0.003056 \\
\hline RE & Electricity & 0.000753 & MJ & 0.022 & 0.000016566 \\
\hline RE & Wastewater & 1.91 & $\mathrm{~L}$ & 0.0013 & 0.002483 \\
\hline RE & Waste to recycling (secondary packaging) & 0.04671 & $\mathrm{~kg}$ & 0.06 & 0.0028026 \\
\hline S & Recycled corrugated board savings & -0.042039 & MJ & 0.14 & -0.00588546 \\
\hline $\mathrm{RE}$ & Waste to landfill (secondary packaging) & 0.00729 & $\mathrm{~kg}$ & 0.99 & 0.0072171 \\
\hline RE & Waste to energy (tertiary packaging) & -0.0453438 & MJ & 0.022 & -0.000997564 \\
\hline RE & Waste to landfill (tertiary packaging) & 0.00047 & $\mathrm{~kg}$ & 0.99 & 0.0004653 \\
\hline S & Energy from thermal treatment & -0.0106596 & MJ & 0.022 & -0.000234511 \\
\hline TR & Transport lorry & 50 & $\mathrm{~kg}^{*} \mathrm{~km}$ & 0.00003 & 0.0015 \\
\hline PA & Plastic bags 1 bag weight $0.0075 \mathrm{~kg}$ and costs $5 p$ & 0.0043 & $\mathrm{~kg}$ & 6.6 & 0.02838 \\
\hline TR & Consumer's car & 0.135 & $\mathrm{~km}$ & 0.12 & 0.0162 \\
\hline $\mathrm{CO}$ & Waste to landfill (plastic bags) & 0.002494 & $\mathrm{~kg}$ & 0.1 & 0.0002494 \\
\hline $\mathrm{CO}$ & Waste to thermal treatment (plastic bags) & 0.001806 & $\mathrm{~kg}$ & 0.99 & 0.00178794 \\
\hline S & Energy from thermal treatment & -0.03315816 & MJ & 0.022 & -0.00072948 \\
\hline $\mathrm{CO}$ & Electricity & 0.0524 & MJ & 0.022 & 0.0011528 \\
\hline $\mathrm{CO}$ & Detergent & 0.0016 & $\mathrm{~kg}$ & 6.65 & 0.01064 \\
\hline $\mathrm{CO}$ & Water & 0.187 & $\mathrm{~L}$ & 0.0016 & 0.0002992 \\
\hline $\mathrm{CO}$ & $\begin{array}{l}\text { Wastewater } \\
\text { Waste to thermal treatment (primary packaging folding }\end{array}$ & 0.187 & L & 0.0013 & 0.0002431 \\
\hline EOL & box) & 0.00696 & $\mathrm{~kg}$ & 0.99 & 0.0068904 \\
\hline EOL & Waste to Landfill (primary packaging folding box) & 0.00783 & $\mathrm{~kg}$ & 0.1 & 0.000783 \\
\hline
\end{tabular}


Table S2 continued

\begin{tabular}{|c|c|c|c|c|c|}
\hline Whole cakes & Activities & $\begin{array}{r}\text { Value per functional unit } \\
(1 \mathrm{~kg} \text { of product })\end{array}$ & Unit & Unit price $(£)$ & Total cost $(\mathfrak{\Sigma})$ \\
\hline EOL & $\begin{array}{l}\text { Waster to recycling plant (primary packaging folding } \\
\text { box) }\end{array}$ & 0.07221 & $\mathrm{~kg}$ & 0.06 & 0.0043326 \\
\hline s & Recycled folding box savings & -0.017226 & $\mathrm{~kg}$ & 0.14 & -0.00241164 \\
\hline s & Energy from thermal treatment & -0.0324684 & MJ & 0.022 & -0.000714305 \\
\hline EOL & Waste to thermal treatment (primary packaging, plastic) & 0.00252 & $\mathrm{~kg}$ & 0.99 & 0.0024948 \\
\hline EOL & Waste to landfill (primary packaging, plastic) & 0.00348 & $\mathrm{~kg}$ & 0.1 & 0.000348 \\
\hline S & Energy from thermal treatment & -0.0462672 & MJ & 0.022 & -0.001017878 \\
\hline EOL & Bio-waste to composting plant & 0.024 & $\mathrm{~kg}$ & 0.06 & 0.00144 \\
\hline S & Savings compost & -0.00144 & $\mathrm{~kg}$ & 0.125 & -0.00018 \\
\hline EOL & Bio-waste to landfill & 0.176 & $\mathrm{~kg}$ & 0.1 & 0.0176 \\
\hline Cake slices & Activities & $\begin{array}{l}\text { Value per functional unit } \\
\text { ( } 1 \mathrm{~kg} \text { of product) }\end{array}$ & Unit & Unit price $(\mathfrak{E})$ & Total cost $(\mathfrak{£})$ \\
\hline RM & Sugar - icing & 0.23218 & $\mathrm{~kg}$ & 0.37 & 0.0859066 \\
\hline RM & Starch & 0.00442 & $\mathrm{~kg}$ & 1.12 & 0.0049504 \\
\hline RM & Water & 0.0234 & $\mathrm{~L}$ & 0.0016 & 0.00003744 \\
\hline TR & Transport lorry (raw materials to manufacturer) & 0.884 & $\mathrm{~kg}^{*} \mathrm{~km}$ & 0.00003 & 0.00002652 \\
\hline RM & Vanilla flavour & 0.0012 & $\mathrm{~kg}$ & 11.97 & 0.014364 \\
\hline RM & Sugar & 0.06924 & $\mathrm{~kg}$ & 0.37 & 0.0256188 \\
\hline RM & Butter & 0.02472 & $\mathrm{~kg}$ & 1.9437 & 0.048048264 \\
\hline RM & Palm oil & 0.12772 & $\mathrm{~kg}$ & 0.3698 & 0.047230856 \\
\hline TR & Transport ship (raw materials to manufacturer) & 2027.4 & $\mathrm{~kg}^{*} \mathrm{~km}$ & $5.00 \mathrm{E}-08$ & 0.00010137 \\
\hline TR & Transport lorry (raw materials to manufacturer) & 17.544 & $\mathrm{~kg}^{*} \mathrm{~km}$ & 0.00003 & 0.00052632 \\
\hline RM & Flour white & 0.1488 & $\mathrm{~kg}$ & 0.936 & 0.1392768 \\
\hline RM & Palm oil & 0.031 & $\mathrm{~kg}$ & 0.3698 & 0.0114638 \\
\hline RM & Sugar & 0.1426 & $\mathrm{~kg}$ & 0.37 & 0.052762 \\
\hline RM & Soda & 0.0186 & $\mathrm{~kg}$ & 0.33 & 0.006138 \\
\hline RM & Salt & 0.003968 & $\mathrm{~kg}$ & 0.13 & 0.00051584 \\
\hline RM & Water & 0.0279 & $\mathrm{~L}$ & 0.0016 & 0.00004464 \\
\hline RM & Fructose - glucose & 0.031 & $\mathrm{~kg}$ & 3 & 0.093 \\
\hline RM & Eggs pasteurised & 0.186 & $\mathrm{~kg}$ & 5.99 & 1.11414 \\
\hline RM & Glycerine & 0.0279 & $\mathrm{~kg}$ & 2.4 & 0.06696 \\
\hline RM & Acetic acid & 0.000744 & $\mathrm{~kg}$ & 0.46 & 0.00034224 \\
\hline
\end{tabular}


Table S2 continued

\begin{tabular}{|c|c|c|c|c|c|}
\hline Cake slices & Activities & $\begin{array}{r}\text { Value per functional unit } \\
(1 \mathrm{~kg} \text { of product) }\end{array}$ & Unit & Unit price (£) & Total cost $(£)$ \\
\hline $\mathrm{RM}$ & Sorbic acid & 0.001488 & $\mathrm{~kg}$ & 79.19 & 0.11783472 \\
\hline TR & Transport lorry (raw materials to manufacturer) & 93.62 & $\mathrm{~kg}^{*} \mathrm{~km}$ & 0.00003 & 0.0028086 \\
\hline TR & Transport ship (raw materials to manufacturer) & 491.66 & $\mathrm{~kg}^{*} \mathrm{~km}$ & 5.00E-08 & 0.000024583 \\
\hline MA & Electricity & 0.5522 & MJ & 0.022 & 0.0121484 \\
\hline MA & Gas & 0.581 & MJ & 0.0054 & 0.0031374 \\
\hline $\mathrm{Ma}$ & Steam & 0.536 & MJ & 0.034 & 0.018224 \\
\hline MA & Lubricants & 0.0000062 & $\mathrm{~kg}$ & 0.664 & 4.1168E-06 \\
\hline MA & Wastewater & 0.31 & $\mathrm{~L}$ & 0.0013 & 0.000403 \\
\hline MA & Water & 0.31 & $\mathrm{~L}$ & 0.0016 & 0.000496 \\
\hline PA & Polyethylene bottle & 0.0667 & $\mathrm{~kg}$ & 1.57 & 0.104719 \\
\hline PA & Polyethylene film & 0.00909 & $\mathrm{~kg}$ & 1.57 & 0.0142713 \\
\hline PA & Folding box & 0.0306 & $\mathrm{~kg}$ & 0.14 & 0.004284 \\
\hline PA & Cardboard secondary packaging & 0.057 & $\mathrm{~kg}$ & 0.14 & 0.00798 \\
\hline TR & Transport lorry (packaging to manufacturer) & 24.5 & $\mathrm{~kg}^{*} \mathrm{~km}$ & 0.00003 & 0.000735 \\
\hline DC & Water & 0.00796 & L & 0.0016 & 0.000012736 \\
\hline TR & Transport lorry & 150 & $\mathrm{~kg}^{*} \mathrm{~km}$ & 0.00003 & 0.0045 \\
\hline DC & Electricity & 0.00000235 & MJ & 0.022 & 5.17E-08 \\
\hline DC & Wastewater & 0.00796 & $\mathrm{~L}$ & 0.0013 & 0.000010348 \\
\hline DC & LDPE tertiary packaging & 0.00047 & $\mathrm{~kg}$ & 1.57 & 0.0007379 \\
\hline TR & Transport lorry (packaging to distribution centre) & 0.0705 & $\mathrm{~kg}^{*} \mathrm{~km}$ & 0.00003 & 0.000002115 \\
\hline RE & Water & 2.39 & L & 0.0016 & 0.003824 \\
\hline RE & Electricity & 0.000942 & MJ & 0.022 & 0.000020724 \\
\hline $\mathrm{RE}$ & Wastewater & 2.39 & $\mathrm{~L}$ & 0.0013 & 0.003107 \\
\hline RE & Waste to recycling (secondary packaging) & 0.049305 & $\mathrm{~kg}$ & 0.06 & 0.0029583 \\
\hline S & Recycled corrugated board savings & -0.0443745 & $\mathrm{~kg}$ & 0.14 & -0.00621243 \\
\hline $\mathrm{RE}$ & Waste to landfill (secondary packaging) & 0.007695 & $\mathrm{~kg}$ & 0.99 & 0.00761805 \\
\hline RE & Waste to energy (tertiary packaging) & -0.0478629 & MJ & 0.022 & -0.001052984 \\
\hline $\mathrm{RE}$ & Waste to landfill (tertiary packaging) & 0.00047 & $\mathrm{~kg}$ & 0.99 & 0.0004653 \\
\hline S & Energy from thermal treatment & -0.0106596 & MJ & 0.022 & -0.000234511 \\
\hline TR & Transport lorry & 50 & $\mathrm{~kg}^{*} \mathrm{~km}$ & 0.00003 & 0.0015 \\
\hline PA & Plastic bags 1 bag weight $0.0075 \mathrm{~kg}$ and costs $5 p$ & 0.0054 & $\mathrm{~kg}$ & 6.6 & 0.03564 \\
\hline TR & Consumer's car & 0.135 & $\mathrm{~km}$ & 0.12 & 0.0162 \\
\hline
\end{tabular}


Table S2 continued

\begin{tabular}{|c|c|c|c|c|c|}
\hline Cake slices & Activities & $\begin{array}{r}\text { Value per functional unit } \\
(1 \mathrm{~kg} \text { of product) }\end{array}$ & Unit & Unit price (£) & Total cost $(£)$ \\
\hline $\mathrm{CO}$ & Waste to landfill (plastic bags) & 0.003132 & $\mathrm{~kg}$ & 0.1 & 0.0003132 \\
\hline $\mathrm{CO}$ & Waste to thermal treatment (plastic bags) & 0.002268 & $\mathrm{~kg}$ & 0.99 & 0.00224532 \\
\hline S & Energy from thermal treatment & -0.04164048 & MJ & 0.022 & -0.000916091 \\
\hline $\mathrm{CO}$ & Electricity & 0.0393 & MJ & 0.022 & 0.0008646 \\
\hline $\mathrm{CO}$ & Detergent & 0.0016 & $\mathrm{~kg}$ & 6.65 & 0.01064 \\
\hline $\mathrm{CO}$ & Water & 0.14 & $\mathrm{~L}$ & 0.0016 & 0.000224 \\
\hline $\mathrm{CO}$ & $\begin{array}{l}\text { Wastewater } \\
\text { Waste to thermal treatment (primary packaging folding }\end{array}$ & 0.14 & L & 0.0013 & 0.000182 \\
\hline EOL & box) & 0.002448 & $\mathrm{~kg}$ & 0.99 & 0.00242352 \\
\hline EOL & $\begin{array}{l}\text { Waste to Landfill (primary packaging folding box) } \\
\text { Waster to recycling plant (primary packaging folding }\end{array}$ & 0.002754 & $\mathrm{~kg}$ & 0.1 & 0.0002754 \\
\hline EOL & box) & 0.025398 & $\mathrm{~kg}$ & 0.06 & 0.00152388 \\
\hline S & Recycled folding box savings & -0.0060588 & $\mathrm{~kg}$ & 0.14 & -0.000848232 \\
\hline S & Energy from thermal treatment & -0.01141992 & MJ & 0.022 & -0.000251238 \\
\hline EOL & Waste to thermal treatment (primary packaging, plastic) & 0.031836 & $\mathrm{~kg}$ & 0.99 & 0.03151764 \\
\hline EOL & Waste to landfill (primary packaging, plastic) & 0.043964 & $\mathrm{~kg}$ & 0.1 & 0.0043964 \\
\hline S & Energy from thermal treatment & -0.58450896 & MJ & 0.022 & -0.012859197 \\
\hline EOL & Bio-waste to composting plant & 0.024 & $\mathrm{~kg}$ & 0.06 & 0.00144 \\
\hline S & Savings compost & -0.00144 & $\mathrm{~kg}$ & 0.125 & -0.00018 \\
\hline EOL & Bio-waste to landfill & 0.176 & $\mathrm{~kg}$ & 0.1 & 0.0176 \\
\hline Pies & Activities & $\begin{array}{l}\text { Value per functional unit } \\
\text { ( } 1 \mathrm{~kg} \text { of product })\end{array}$ & Unit & Unit price (£) & Total cost $(£)$ \\
\hline $\mathrm{RM}$ & Sugar & 0.042 & $\mathrm{~kg}$ & 0.37 & 0.01554 \\
\hline $\mathrm{RM}$ & Water & 0.084 & $\mathrm{~kg}$ & 0.0016 & 0.0001344 \\
\hline RM & Apple & 0.1008 & $\mathrm{~kg}$ & 0,61 & 0.061488 \\
\hline MA & Electricity (pre-processing apple filling) & 0.042714 & MJ & 0.022 & 0.000939708 \\
\hline MA & Bio-waste to composting plant & 0.0168 & $\mathrm{~kg}$ & 0.06 & 0.001008 \\
\hline S & Compost & -0.0084 & $\mathrm{~kg}$ & 0.125 & -0.00105 \\
\hline TR & Transport lorry (raw materials to manufacturer) & 20.16 & $\mathrm{~kg}^{*} \mathrm{~km}$ & 0.00003 & 0.0006048 \\
\hline $\mathrm{RM}$ & Flour white & 0.35313 & $\mathrm{~kg}$ & 0.936 & 0.33052968 \\
\hline $\mathrm{RM}$ & Palm oil & 0.24253 & $\mathrm{~kg}$ & 0.3698 & 0.089687594 \\
\hline $\mathrm{RM}$ & Sugar & 0.05372 & $\mathrm{~kg}$ & 0.37 & 0.0198764 \\
\hline
\end{tabular}


Table S2 continued

\begin{tabular}{|c|c|c|c|c|c|}
\hline Pies & Activities & $\begin{array}{r}\text { Value per functional unit } \\
(1 \mathrm{~kg} \text { of product })\end{array}$ & Unit & Unit price $(£)$ & Total cost $(£)$ \\
\hline RM & Eggs pasteurised & 0.13746 & $\mathrm{~kg}$ & 5.99 & 0.8233854 \\
\hline TR & Transport lorry (raw materials to manufacturer) & 220.252 & $\mathrm{~kg}^{*} \mathrm{~km}$ & 0.00003 & 0.00660756 \\
\hline TR & Transport ship (raw materials to manufacturer) & 3847.3 & $\mathrm{~kg}^{*} \mathrm{~km}$ & $5.00 \mathrm{E}-08$ & 0.000192365 \\
\hline MA & Electricity & 0.826 & MJ & 0.022 & 0.018172 \\
\hline MA & Gas & 1.06 & MJ & 0.0054 & 0.005724 \\
\hline $\mathrm{Ma}$ & Steam & 0.986 & MJ & 0.034 & 0.033524 \\
\hline MA & Lubricants & 0.0000079 & $\mathrm{~kg}$ & 0.664 & $5.2456 \mathrm{E}-06$ \\
\hline MA & Wastewater & 0.395 & $\mathrm{~L}$ & 0.0013 & 0.0005135 \\
\hline MA & Water & 0.395 & $\mathrm{~L}$ & 0.0016 & 0.000632 \\
\hline PA & Aluminium & 0.0136 & $\mathrm{~kg}$ & 1.22 & 0.016592 \\
\hline PA & Polyethylene bottle & 0.0246 & $\mathrm{~kg}$ & 1.57 & 0.038622 \\
\hline PA & Folding box & 0.0832 & $\mathrm{~kg}$ & 0.14 & 0.011648 \\
\hline PA & Cardboard secondary packaging & 0.064 & $\mathrm{~kg}$ & 0.14 & 0.00896 \\
\hline TR & Transport lorry (packaging to manufacturer) & 27.83 & $\mathrm{~kg}^{*} \mathrm{~km}$ & 0.00003 & 0.0008349 \\
\hline DC & Water & 0.00668 & $\mathrm{~L}$ & 0.0016 & 0.000010688 \\
\hline TR & Transport lorry (manufacturer to distribution centre) & 150 & $\mathrm{~kg}^{*} \mathrm{~km}$ & 0.00003 & 0.0045 \\
\hline DC & Electricity & 0.00000198 & MJ & 0.022 & 4.356E-08 \\
\hline DC & Wastewater & 0.00668 & $\mathrm{~L}$ & 0.0013 & 0.000008684 \\
\hline DC & LDPE tertiary packaging & 0.00047 & $\mathrm{~kg}$ & 1.57 & 0.0007379 \\
\hline TR & Transport lorry (packaging to distribution centre) & 0.0705 & $\mathrm{~kg}^{*} \mathrm{~km}$ & 0.00003 & 0.000002115 \\
\hline RE & Water & 2 & L & 0.0016 & 0.0032 \\
\hline RE & Electricity & 0.000791 & MJ & 0.022 & 0.000017402 \\
\hline RE & Wastewater & 2 & $\mathrm{~L}$ & 0.0013 & 0.0026 \\
\hline RE & Waste to recycling (secondary packaging) & 0.05536 & $\mathrm{~kg}$ & 0.06 & 0.0033216 \\
\hline S & Recycled corrugated board savings & -0.049824 & $\mathrm{~kg}$ & 0.14 & -0.00697536 \\
\hline RE & Waste to landfill (secondary packaging) & 0.00864 & $\mathrm{~kg}$ & 0.99 & 0.0085536 \\
\hline RE & Waste to energy (tertiary packaging) & 0.0537408 & $\mathrm{~kg}$ & 0.022 & 0.001182298 \\
\hline RE & Waste to landfill (tertiary packaging) & 0.00047 & $\mathrm{~kg}$ & 0.99 & 0.0004653 \\
\hline S & Energy from thermal treatment & -0.0106596 & MJ & 0.022 & -0.000234511 \\
\hline TR & Transport lorry & 50 & $\mathrm{~kg}^{*} \mathrm{~km}$ & 0.00003 & 0.0015 \\
\hline PA & Plastic bags 1 bag weight $0.0075 \mathrm{~kg}$ and costs $5 p$ & 0.0045 & $\mathrm{~kg}$ & 6.6 & 0.0297 \\
\hline TR & Consumer's car & 0.135 & $\mathrm{~km}$ & 0.12 & 0.0162 \\
\hline $\mathrm{CO}$ & Waste to landfill (plastic bags) & 0.00261 & $\mathrm{~kg}$ & 0.1 & 0.000261 \\
\hline
\end{tabular}


Table S2 continued

\begin{tabular}{|c|c|c|c|c|c|}
\hline Pies & Activities & $\begin{array}{r}\text { Value per functional unit } \\
(1 \mathrm{~kg} \text { of product })\end{array}$ & Unit & Unit price $(£)$ & Total cost $(£)$ \\
\hline $\mathrm{CO}$ & Waste to thermal treatment (plastic bags) & 0.00189 & $\mathrm{~kg}$ & 0.99 & 0.0018711 \\
\hline S & Energy from thermal treatment & -0.0347004 & MJ & 0.022 & -0.000763409 \\
\hline $\mathrm{CO}$ & Electricity & 0.0393 & MJ & 0.022 & 0.0008646 \\
\hline $\mathrm{CO}$ & Detergent & 0.0012 & $\mathrm{~kg}$ & 6.65 & 0.00798 \\
\hline $\mathrm{CO}$ & Water & 0.14 & $\mathrm{~L}$ & 0.0016 & 0.000224 \\
\hline $\mathrm{CO}$ & Wastewater & 0.14 & $\mathrm{~L}$ & 0.0013 & 0.000182 \\
\hline EOL & $\begin{array}{l}\text { Waste to thermal treatment (Primary packaging folding } \\
\text { box) }\end{array}$ & 0.001088 & $\mathrm{~kg}$ & 0.99 & 0.00107712 \\
\hline EOL & $\begin{array}{l}\text { Waste to Landfill (primary packaging folding box) } \\
\text { Waster to recycling plant (primary packaging folding }\end{array}$ & 0.001224 & $\mathrm{~kg}$ & 0.1 & 0.0001224 \\
\hline EOL & box) & 0.011288 & $\mathrm{~kg}$ & 0.06 & 0.00067728 \\
\hline S & Recycled folding box savings & -0.0026928 & $\mathrm{~kg}$ & 0.14 & -0.000376992 \\
\hline S & Energy from thermal treatment & -0.00507552 & MJ & 0.022 & -0.000111661 \\
\hline EOL & Waste to thermal treatment (Primary packaging, plastic) & 0.010332 & $\mathrm{~kg}$ & 0.99 & 0.01022868 \\
\hline EOL & Waste to landfill (Primary packaging, plastic) & 0.014268 & $\mathrm{~kg}$ & 0.1 & 0.0014268 \\
\hline S & Energy from thermal treatment & -0.18969552 & MJ & 0.022 & -0.004173301 \\
\hline EOL & Bio-waste to composting plant & 0.024 & $\mathrm{~kg}$ & 0.06 & 0.00144 \\
\hline S & Savings compost & -0.00144 & $\mathrm{~kg}$ & 0.125 & -0.00018 \\
\hline EOL & Bio-waste to landfill & 0.176 & $\mathrm{~kg}$ & 0.1 & 0.0176 \\
\hline EOL & Waste to recycling (Primary packaging Aluminium) & 0.0079152 & $\mathrm{~kg}$ & 0.06 & 0.000474912 \\
\hline EOL & Waste to landfill (Primary packaging Aluminium) & 0.0056848 & $\mathrm{~kg}$ & 0.1 & 0.00056848 \\
\hline $\mathrm{S}$ & Savings aluminium & -0.0079152 & $\mathrm{~kg}$ & 1.22 & -0.009656544 \\
\hline Cupcakes & Activities & $\begin{array}{l}\text { Value per functional unit } \\
\text { (1 kg of product) }\end{array}$ & Unit & Unit price $(£)$ & Total cost $(£)$ \\
\hline $\mathrm{RM}$ & Sugar icing & 0.36315 & $\mathrm{~kg}$ & 0.37 & 0.1343655 \\
\hline RM & Citrus & 0.018 & $\mathrm{~kg}$ & 0.793 & 0.014274 \\
\hline RM & butter & 0.06885 & $\mathrm{~kg}$ & 1.9437 & 0.133823745 \\
\hline TR & Transport lorry (raw materials to manufacturer) & 13.77 & $\mathrm{~kg}^{*} \mathrm{~km}$ & 0.00003 & 0.0004131 \\
\hline RM & Flour white & 0.132 & $\mathrm{~kg}$ & 0.936 & 0.123552 \\
\hline RM & Palm oil & 0.0825 & $\mathrm{~kg}$ & 0.3698 & 0.0305085 \\
\hline RM & Sugar & 0.099 & $\mathrm{~kg}$ & 0.37 & 0.03663 \\
\hline RM & Soda & 0.01925 & $\mathrm{~kg}$ & 0.33 & 0.0063525 \\
\hline $\mathrm{RM}$ & Water & 0.044 & $\mathrm{~L}$ & 0.0016 & 0.0000704 \\
\hline
\end{tabular}


Table S2 continued

\begin{tabular}{|c|c|c|c|c|c|}
\hline Cupcakes & Activities & $\begin{array}{r}\text { Value per functional unit } \\
\text { (1 kg of product) }\end{array}$ & Unit & Unit price $(£)$ & Total cost $(£)$ \\
\hline RM & Fructose - Glucose & 0.0275 & $\mathrm{~kg}$ & 3 & 0.0825 \\
\hline RM & Sorbic acid & 0.00132 & $\mathrm{~kg}$ & 79.19 & 0.1045308 \\
\hline RM & Eggs pasteurised & 0.1265 & $\mathrm{~kg}$ & 5.99 & 0.757735 \\
\hline RM & Acetic acid & 0.00066 & $\mathrm{~kg}$ & 0.46 & 0.0003036 \\
\hline RM & Glycerine & 0.0165 & $\mathrm{~kg}$ & 2.4 & 0.0396 \\
\hline TR & Transport lorry (raw materials to manufacturer) & 102.85 & $\mathrm{~kg}^{*} \mathrm{~km}$ & 0.00003 & 0.0030855 \\
\hline TR & Transport ship (raw materials to manufacturer) & 1309 & $\mathrm{~kg}^{*} \mathrm{~km}$ & $5.00 \mathrm{E}-08$ & 0.00006545 \\
\hline MA & Electricity & 0.4941 & MJ & 0.022 & 0.0108702 \\
\hline MA & Gas & 0.515 & MJ & 0.0054 & 0.002781 \\
\hline Ma & Steam & 0.4748 & MJ & 0.034 & 0.0161432 \\
\hline MA & Lubricants & 0.0000055 & $\mathrm{~kg}$ & 0.664 & 0.000003652 \\
\hline MA & Wastewater & 0.275 & $\mathrm{~L}$ & 0.0013 & 0.0003575 \\
\hline MA & Water & 0.275 & L & 0.0016 & 0.00044 \\
\hline PA & Paper & 0.0331 & $\mathrm{~kg}$ & 0.14 & 0.004634 \\
\hline PA & Polyethylene bottle & 0.0922 & $\mathrm{~kg}$ & 1.57 & 0.144754 \\
\hline PA & Folding box & 0.0305 & $\mathrm{~kg}$ & 0.14 & 0.00427 \\
\hline PA & Cardboard secondary packaging & 0.147 & $\mathrm{~kg}$ & 0.14 & 0.02058 \\
\hline TR & Transport lorry (packaging to manufacturer) & 45.33 & $\mathrm{~kg}^{*} \mathrm{~km}$ & 0.00003 & 0.0013599 \\
\hline DC & Water & 0.0137 & $\mathrm{~L}$ & 0.0016 & 0.00002192 \\
\hline TR & Transport lorry (distribution centre to manufacturer) & 150 & $\mathrm{~kg}^{*} \mathrm{~km}$ & 0.00003 & 0.0045 \\
\hline DC & Electricity & 0.00000404 & MJ & 0.022 & $8.888 \mathrm{E}-08$ \\
\hline DC & Wastewater & 0.0137 & $\mathrm{~L}$ & 0.0013 & 0.00001781 \\
\hline DC & LDPE tertiary packaging & 0.00047 & $\mathrm{~kg}$ & 1.57 & 0.0007379 \\
\hline TR & Transport lorry (packaging to distribution centre) & 0.0705 & $\mathrm{~kg}^{*} \mathrm{~km}$ & 0.00003 & 0.000002115 \\
\hline RE & Water & 4.1 & $\mathrm{~L}$ & 0.0016 & 0.00656 \\
\hline RE & Electricity & 0.00162 & MJ & 0.022 & 0.00003564 \\
\hline RE & Wastewater & 4.1 & $\mathrm{~L}$ & 0.0013 & 0.00533 \\
\hline RE & Waste to recycling (secondary packaging) & 0.127155 & $\mathrm{~kg}$ & 0.06 & 0.0076293 \\
\hline S & Recycled corrugated board savings & -0.1144395 & $\mathrm{~kg}$ & 0.14 & -0.01602153 \\
\hline $\mathrm{RE}$ & Waste to landfill (secondary packaging) & 0.019845 & $\mathrm{~kg}$ & 0.99 & 0.01964655 \\
\hline RE & Waste to energy (tertiary packaging) & -0.1234359 & $\mathrm{~kg}$ & 0.022 & -0.00271559 \\
\hline
\end{tabular}


Table S2 continued

\begin{tabular}{|c|c|c|c|c|c|}
\hline Cupcakes & Activities & $\begin{array}{r}\text { Value per functional unit } \\
\text { (1 kg of product) }\end{array}$ & Unit & Unit price $(£)$ & Total cost $(£)$ \\
\hline RE & Waste to landfill (tertiary packaging) & 0.00047 & $\mathrm{~kg}$ & 0.99 & 0.0004653 \\
\hline S & Energy from thermal treatment & -0.0106596 & MJ & 0.022 & -0.000234511 \\
\hline TR & Transport lorry & 50 & $\mathrm{~kg}^{*} \mathrm{~km}$ & 0.00003 & 0.0015 \\
\hline PA & Plastic bags 1 bag weight $0.0075 \mathrm{~kg}$ and costs $5 p$ & 0.0091 & $\mathrm{~kg}$ & 6.6 & 0.06006 \\
\hline TR & Consumer's car & 0.135 & $\mathrm{~km}$ & 0.12 & 0.0162 \\
\hline $\mathrm{CO}$ & Waste to landfill (plastic bags) & 0.005278 & $\mathrm{~kg}$ & 0.1 & 0.0005278 \\
\hline $\mathrm{CO}$ & Waste to thermal treatment (plastic bags) & 0.003822 & $\mathrm{~kg}$ & 0.99 & 0.00378378 \\
\hline S & Energy from thermal treatment & -0.08305206 & MJ & 0.022 & -0.001827145 \\
\hline $\mathrm{CO}$ & Electricity & 0.105 & MJ & 0.022 & 0.00231 \\
\hline $\mathrm{CO}$ & Detergent & 0.0016 & $\mathrm{~kg}$ & 6.65 & 0.01064 \\
\hline $\mathrm{CO}$ & Water & 0.374 & $\mathrm{~L}$ & 0.0016 & 0.0005984 \\
\hline $\mathrm{CO}$ & $\begin{array}{l}\text { Wastewater } \\
\text { Waste to thermal treatment (primary packaging folding }\end{array}$ & 0.374 & $\mathrm{~L}$ & 0.0013 & 0.0004862 \\
\hline EOL & box) & 0.00244 & $\mathrm{~kg}$ & 0.99 & 0.0024156 \\
\hline EOL & $\begin{array}{l}\text { Waste to Landfill (primary packaging folding box) } \\
\text { Waster to recycling plant (primary packaging folding }\end{array}$ & 0.002745 & $\mathrm{~kg}$ & 0.1 & 0.0002745 \\
\hline EOL & box) & 0.025315 & $\mathrm{~kg}$ & 0.06 & 0.0015189 \\
\hline S & Recycled folding box savings & -0.006039 & $\mathrm{~kg}$ & 0.14 & -0.00084546 \\
\hline S & Energy from thermal treatment & -0.0113826 & MJ & 0.022 & -0.000250417 \\
\hline EOL & Waste to thermal treatment (primary packaging, plastic) & 0.038724 & $\mathrm{~kg}$ & 0.99 & 0.03833676 \\
\hline EOL & Waste to landfill (primary packaging, plastic) & 0.053476 & $\mathrm{~kg}$ & 0.1 & 0.0053476 \\
\hline S & Energy from thermal treatment & -0.87826032 & MJ & 0.022 & -0.019321727 \\
\hline EOL & Bio-waste to composting plant & 0.024 & $\mathrm{~kg}$ & 0.06 & 0.00144 \\
\hline S & Savings compost & -0.00144 & $\mathrm{~kg}$ & 0.125 & -0.00018 \\
\hline EOL & Bio-waste to landfill & 0.176 & $\mathrm{~kg}$ & 0.1 & 0.0176 \\
\hline EOL & Waste to recycling (primary packaging, paper) & 0.027473 & $\mathrm{~kg}$ & 0.06 & 0.00164838 \\
\hline EOL & Waste to landfill (primary packaging , paper) & 0.002979 & $\mathrm{~kg}$ & 0.1 & 0.0002979 \\
\hline EOL & Waste to thermal treatment (primary packaging, paper) & 0.002648 & $\mathrm{~kg}$ & 0.99 & 0.00262152 \\
\hline S & Recycled paper & -0.0247257 & $\mathrm{~kg}$ & 0.14 & -0.003461598 \\
\hline S & Savings thermal treatment & -0.01647056 & MJ & 1.22 & -0.020094083 \\
\hline
\end{tabular}


Table S2 continued

\begin{tabular}{|c|c|c|c|c|c|}
\hline Cheesecake & Activities & $\begin{array}{l}\text { Value per functional unit } \\
\text { (1 kg of product) }\end{array}$ & Unit & Unit price $(£)$ & Total cost $(£)$ \\
\hline RM & Flour white & 0.05264 & $\mathrm{~kg}$ & 0.936 & 0.04927104 \\
\hline RM & Four wholemeal & 0.01232 & $\mathrm{~kg}$ & 1 & 0.01232 \\
\hline RM & Palm oil & 0.0224 & $\mathrm{~kg}$ & 0.3698 & 0.00828352 \\
\hline RM & Sugar & 0.01568 & $\mathrm{~kg}$ & 0.37 & 0.0058016 \\
\hline RM & Soda & 0.00224 & $\mathrm{~kg}$ & 0.33 & 0.0007392 \\
\hline RM & Salt & 0.00112 & $\mathrm{~kg}$ & 0.13 & 0.0001456 \\
\hline TR & Transport lorry (raw materials to manufacturer) & 24.864 & $\mathrm{~kg}^{*} \mathrm{~km}$ & 0.00003 & 0.00074592 \\
\hline TR & Transport ship (raw materials to manufacturer) & 355.04 & $\mathrm{~kg}^{*} \mathrm{~km}$ & $5.00 \mathrm{E}-08$ & 0.000017752 \\
\hline RM & Strawberry & 0.15 & $\mathrm{~kg}$ & 2.26 & 0.339 \\
\hline TR & Transport lorry (raw materials to manufacturer) & 30 & $\mathrm{~kg}^{*} \mathrm{~km}$ & 0.00003 & 0.0009 \\
\hline RM & Soft cheese & 0.209592 & $\mathrm{~kg}$ & 2.2813 & 0.47814223 \\
\hline MA & Electricity & 0.196308 & MJ & 0.022 & 0.004318776 \\
\hline RM & Water & 0.089298 & $\mathrm{~L}$ & 0.0016 & 0.000142877 \\
\hline RM & Milk powder & 0.208116 & $\mathrm{~kg}$ & 2.185 & 0.45473346 \\
\hline RM & Citrus & 0.104796 & $\mathrm{~kg}$ & 0.793 & 0.083103228 \\
\hline RM & Milk cream & 0.089298 & $\mathrm{~kg}$ & 0.98 & 0.08751204 \\
\hline TR & Transport lorry (raw materials to manufacturer) & 129.7404 & $\mathrm{~kg}^{*} \mathrm{~km}$ & 0.00003 & 0.003892212 \\
\hline MA & Electricity & 2.2334 & MJ & 0.022 & 0.0491348 \\
\hline MA & Gas & 0.466 & MJ & 0.0054 & 0.0025164 \\
\hline $\mathrm{Ma}$ & Steam & 0.1381 & MJ & 0.034 & 0.0046954 \\
\hline MA & Lubricants & 0.00000112 & $\mathrm{~kg}$ & 0.664 & 7.4368E-07 \\
\hline MA & Wastewater & 0.056 & $\mathrm{~L}$ & 0.0013 & 0.0000728 \\
\hline MA & Water & 0.056 & $\mathrm{~L}$ & 0.0016 & 0.0000896 \\
\hline PA & Polypropylene & 0.0253 & $\mathrm{~kg}$ & 1.69 & 0.042757 \\
\hline PA & Polyethylene bottle & 0.0016 & $\mathrm{~kg}$ & 1.57 & 0.002512 \\
\hline PA & Folding box & 0.0472 & $\mathrm{~kg}$ & 0.14 & 0.006608 \\
\hline PA & Cardboard secondary packaging & 0.058 & $\mathrm{~kg}$ & 0.14 & 0.00812 \\
\hline TR & Transport lorry (packaging to manufacturer) & 19.82 & $\mathrm{~kg}^{*} \mathrm{~km}$ & 0.00003 & 0.0005946 \\
\hline TR & Diesel & 0.00000118 & $\mathrm{~L}$ & 0.24 & $2.832 \mathrm{E}-07$ \\
\hline TR & Refrigerant R134a & 0.000016 & $\mathrm{~kg}$ & 12.8 & 0.0002048 \\
\hline DC & Water & 0.00468 & $\mathrm{~L}$ & 0.0016 & 0.000007488 \\
\hline $\mathrm{DC}$ & Electricity & 0.00000323 & MJ & 0.022 & 7.106E-08 \\
\hline $\mathrm{DC}$ & liquid ammonia & 0.000000357 & $\mathrm{~L}$ & 0.33 & 1.1781E-07 \\
\hline
\end{tabular}


Table S2 continued

\begin{tabular}{|c|c|c|c|c|c|}
\hline Cheesecake & Activities & $\begin{array}{r}\text { Value per functional unit } \\
(1 \mathrm{~kg} \text { of product })\end{array}$ & Unit & Unit price $(£)$ & Total cost $(£)$ \\
\hline TR & Transport lorry (manufacturer to distribution centre) & 150 & $\mathrm{~kg}^{*} \mathrm{~km}$ & 0.00003 & 0.0045 \\
\hline DC & Wastewater & 0.00468 & $\mathrm{~L}$ & 0.0013 & 0.000006084 \\
\hline DC & LDPE tertiary packaging & 0.00047 & $\mathrm{~kg}$ & 1.57 & 0.0007379 \\
\hline TR & Transport lorry (packaging to distribution centre) & 0.0705 & $\mathrm{~kg}^{*} \mathrm{~km}$ & 0.00003 & 0.000002115 \\
\hline TR & Diesel & 0.00000148 & $\mathrm{~L}$ & 0.24 & 3.552E-07 \\
\hline TR & Refrigerant R134a (transport to retailer) & 0.000016 & $\mathrm{~kg}$ & 12.8 & 0.0002048 \\
\hline RE & Water & 0.702 & $\mathrm{~L}$ & 0.0016 & 0.0011232 \\
\hline RE & Refrigerant R134a & 0.00000268 & $\mathrm{~kg}$ & 12.8 & 0.000034304 \\
\hline RE & Electricity & 0.00159 & MJ & 0.022 & 0.00003498 \\
\hline RE & Wastewater & 0.702 & $\mathrm{~L}$ & 0.0013 & 0.0009126 \\
\hline RE & Waste to recycling (secondary packaging) & 0.05017 & $\mathrm{~kg}$ & 0.06 & 0.0030102 \\
\hline S & Recycled corrugated board savings & -0.045153 & $\mathrm{~kg}$ & 0.14 & -0.00632142 \\
\hline RE & Waste to landfill (secondary packaging) & 0.00783 & $\mathrm{~kg}$ & 0.99 & 0.0077517 \\
\hline RE & Waste to energy (tertiary packaging) & -0.0487026 & $\mathrm{~kg}$ & 0.022 & -0.001071457 \\
\hline RE & Waste to landfill (tertiary packaging) & 0.00047 & $\mathrm{~kg}$ & 0.99 & 0.0004653 \\
\hline S & Energy from thermal treatment & -0.0106596 & MJ & 0.022 & -0.000234511 \\
\hline TR & Transport lorry & 50 & $\mathrm{~kg}^{*} \mathrm{~km}$ & 0.00003 & 0.0015 \\
\hline PA & Plastic bags 1 bag weight $0.0075 \mathrm{~kg}$ and costs $5 p$ & 0.0032 & $\mathrm{~kg}$ & 6.6 & 0.02112 \\
\hline TR & Consumer's car & 0.135 & $\mathrm{~km}$ & 0.12 & 0.0162 \\
\hline $\mathrm{CO}$ & Waste to landfill (plastic bags) & 0.001856 & $\mathrm{~kg}$ & 0.1 & 0.0001856 \\
\hline $\mathrm{CO}$ & Waste to thermal treatment (plastic bags) & 0.001344 & $\mathrm{~kg}$ & 0.99 & 0.00133056 \\
\hline S & Energy from thermal treatment & -0.03048192 & MJ & 0.022 & -0.000670602 \\
\hline $\mathrm{CO}$ & Refrigerant R134a & 0.00000456 & $\mathrm{~kg}$ & 12.8 & 0.000058368 \\
\hline $\mathrm{CO}$ & Electricity & 0.4315 & MJ & 0.022 & 0.009493 \\
\hline $\mathrm{CO}$ & Detergent & 0.0024 & $\mathrm{~kg}$ & 6.65 & 0.01596 \\
\hline $\mathrm{CO}$ & Water & 0.281 & $\mathrm{~L}$ & 0.0016 & 0.0004496 \\
\hline $\mathrm{CO}$ & $\begin{array}{l}\text { Wastewater } \\
\text { Waste to thermal treatment (primary packaging folding }\end{array}$ & 0.281 & $L$ & 0.0013 & 0.0003653 \\
\hline EOL & box) & 0.003776 & $\mathrm{~kg}$ & 0.99 & 0.00373824 \\
\hline EOL & $\begin{array}{l}\text { Waste to Landfill (primary packaging folding box) } \\
\text { Waster to recycling plant (primary packaging folding }\end{array}$ & 0.004248 & $\mathrm{~kg}$ & 0.1 & 0.0004248 \\
\hline EOL & box) & 0.039176 & $\mathrm{~kg}$ & 0.06 & 0.00235056 \\
\hline S & Recycled folding box savings & -0.0093456 & $\mathrm{~kg}$ & 0.14 & -0.001308384 \\
\hline S & Energy from thermal treatment & -0.01761504 & MJ & 0.022 & -0.000387531 \\
\hline
\end{tabular}


Table S2 continued

\begin{tabular}{|c|c|c|c|c|c|}
\hline Cheesecake & Activities & $\begin{array}{r}\text { Value per functional unit } \\
\text { (1 kg of product) }\end{array}$ & Unit & Unit price $(£)$ & Total cost (£) \\
\hline EOL & Waste to thermal treatment (primary packaging, plastic) & 0.011298 & $\mathrm{~kg}$ & 0.99 & 0.01118502 \\
\hline EOL & Waste to landfill (primary packaging, plastic) & 0.015602 & $\mathrm{~kg}$ & 0.1 & 0.0015602 \\
\hline S & Energy from thermal treatment & -0.25623864 & MJ & 0.022 & -0.00563725 \\
\hline EOL & Bio-waste to composting plant & 0.024 & $\mathrm{~kg}$ & 0.06 & 0.00144 \\
\hline S & Savings compost & -0.00144 & $\mathrm{~kg}$ & 0.125 & -0.00018 \\
\hline EOL & Bio-waste to landfill & 0.176 & $\mathrm{~kg}$ & 0.1 & 0.0176 \\
\hline $\begin{array}{l}\text { Moulded } \\
\text { chocolate }\end{array}$ & Activities & $\begin{array}{l}\text { Value per functional unit } \\
\text { (1 kg of product) }\end{array}$ & Unit & Unit price $(£)$ & Total cost $(£)$ \\
\hline RM & Sugar & 0.44 & $\mathrm{~kg}$ & 0.37 & 0.1628 \\
\hline RM & Palm oil & 0.05 & $\mathrm{~kg}$ & 0.3698 & 0.01849 \\
\hline RM & Cocoa butter & 0.17 & $\mathrm{~kg}$ & 2.114 & 0.35938 \\
\hline $\mathrm{RM}$ & Cocoa liquor & 0.1 & $\mathrm{~kg}$ & 2.6507 & 0.26507 \\
\hline RM & Milk powder & 0.24 & $\mathrm{~kg}$ & 2.185 & 0.5244 \\
\hline TR & Transport lorry (raw materials to manufacturer) & 73 & $\mathrm{~kg}^{*} \mathrm{~km}$ & 0.00003 & 0.00219 \\
\hline TR & Transport ship (raw materials to manufacturer) & 793 & $\mathrm{~kg}^{*} \mathrm{~km}$ & $5.00 \mathrm{E}-08$ & 0.00003965 \\
\hline MA & Electricity & 1.3586 & MJ & 0.022 & 0.0298892 \\
\hline MA & Ammonia & 0.00021 & $\mathrm{~kg}$ & 0.33 & 0.0000693 \\
\hline MA & Wastewater & 0.5 & $\mathrm{~L}$ & 0.0013 & 0.00065 \\
\hline MA & Water & 0.5 & $\mathrm{~L}$ & 0.0016 & 0.0008 \\
\hline PA & Aluminium & 0.0015 & $\mathrm{~kg}$ & 1.22 & 0.00183 \\
\hline PA & Cardboard secondary packaging & 0.0684 & $\mathrm{~kg}$ & 0.14 & 0.009576 \\
\hline TR & Transport lorry (packaging to manufacturer) & 68.625 & $\mathrm{~kg}^{*} \mathrm{~km}$ & 0.00003 & 0.00205875 \\
\hline DC & Water & 0.00356 & $\mathrm{~L}$ & 0.0016 & 0.000005696 \\
\hline TR & Transport lorry (manufacturer to distribution centre) & 150 & $\mathrm{~kg}^{*} \mathrm{~km}$ & 0.00003 & 0.0045 \\
\hline DC & Electricity & 0.00000105 & MJ & 0.022 & 2.31E-08 \\
\hline DC & Wastewater & 0.00356 & $\mathrm{~L}$ & 0.0013 & 0.000004628 \\
\hline DC & LDPE tertiary packaging & 0.00047 & $\mathrm{~kg}$ & 1.57 & 0.0007379 \\
\hline TR & Transport lorry (packaging to distribution centre) & 0.0705 & $\mathrm{~kg}^{*} \mathrm{~km}$ & 0.00003 & 0.000002115 \\
\hline PA & Plastic bags 1 bag weight $0.0075 \mathrm{~kg}$ and costs $5 p$ & 0.0024 & $\mathrm{~kg}$ & 6.6 & 0.01584 \\
\hline RE & Water & 1.07 & $\mathrm{~L}$ & 0.0016 & 0.001712 \\
\hline RE & Electricity & 0.000421 & MJ & 0.022 & 0.000009262 \\
\hline RE & Wastewater & 1.07 & $\mathrm{~L}$ & 0.0013 & 0.001391 \\
\hline TR & Transport lorry (distribution centre to retailer) & 50 & $\mathrm{~kg}^{*} \mathrm{~km}$ & 0.00003 & 0.0015 \\
\hline
\end{tabular}


Table S2 continued

\begin{tabular}{|c|c|c|c|c|c|}
\hline $\begin{array}{l}\text { Moulded } \\
\text { chocolate }\end{array}$ & Activities & $\begin{array}{r}\text { Value per functional unit } \\
\text { ( } 1 \mathrm{~kg} \text { of product) }\end{array}$ & Unit & Unit price $(£)$ & Total cost $(£)$ \\
\hline RE & Waste to recycling (secondary packaging) & 0.059166 & $\mathrm{~kg}$ & 0.06 & 0.00354996 \\
\hline RE & Waste to energy (secondary packaging) & 0.009234 & $\mathrm{~kg}$ & 0.1 & 0.0009234 \\
\hline S & Recycled corrugated board savings & -0.0532494 & $\mathrm{~kg}$ & 0.14 & -0.007454916 \\
\hline S & Energy from thermal treatment (secondary packaging) & -0.05743548 & MJ & 0.022 & -0.001263581 \\
\hline RE & Waste to energy (tertiary packaging) & 0.00047 & $\mathrm{~kg}$ & 0.99 & 0.0004653 \\
\hline S & Energy from thermal treatment (tertiary packaging) & -0.106596 & MJ & 0.022 & -0.002345112 \\
\hline TR & Consumer's car & 0.135 & $\mathrm{~km}$ & 0.12 & 0.0162 \\
\hline $\mathrm{CO}$ & Waste to landfill (plastic bags) & 0.001392 & $\mathrm{~kg}$ & 0.1 & 0.0001392 \\
\hline EOL & Waste to thermal treatment (plastic bags) & 0.001008 & $\mathrm{~kg}$ & 0.99 & 0.00099792 \\
\hline S & Energy from thermal treatment (plastic bags) & -0.02286144 & MJ & 0.022 & -0.000502952 \\
\hline EOL & Waste to recycling plant (primary packaging) & 0.000873 & $\mathrm{~kg}$ & 0.06 & 0.00005238 \\
\hline EOL & Waste to Landfill (primary packaging) & 0.000627 & $\mathrm{~kg}$ & 0.1 & 0.0000627 \\
\hline S & Saving from recycling (primary packaging) & -0.000873 & $\mathrm{~kg}$ & 1.22 & -0.00106506 \\
\hline $\begin{array}{l}\text { Chocolate } \\
\text { countlines }\end{array}$ & Activities & $\begin{array}{l}\text { Value per functional unit } \\
\text { (1 kg of product) }\end{array}$ & Unit & Unit price (£) & Total cost $(£)$ \\
\hline RM & Sugar & 0.2904 & $\mathrm{~kg}$ & 0.37 & 0.107448 \\
\hline RM & Palm oil & 0.033 & $\mathrm{~kg}$ & 0.3698 & 0.0122034 \\
\hline RM & Cocoa butter & 0.1122 & $\mathrm{~kg}$ & 2.114 & 0.2371908 \\
\hline $\mathrm{RM}$ & Cocoa liquor & 0.066 & $\mathrm{~kg}$ & 2.6507 & 0.1749462 \\
\hline $\mathrm{RM}$ & Milk powder & 0.1584 & $\mathrm{~kg}$ & 2.185 & 0.346104 \\
\hline TR & Transport lorry (raw materials to manufacturer) & 48.18 & $\mathrm{~kg}^{*} \mathrm{~km}$ & 0.00003 & 0.0014454 \\
\hline TR & Transport ship (raw materials to manufacturer) & 523.38 & $\mathrm{~kg}^{*} \mathrm{~km}$ & $5.00 \mathrm{E}-08$ & 0.000026169 \\
\hline $\mathrm{RM}$ & Flour white & 0.1156 & $\mathrm{~kg}$ & 0.936 & 0.1082016 \\
\hline RM & Sugar & 0.0833 & $\mathrm{~kg}$ & 0.37 & 0.030821 \\
\hline $\mathrm{RM}$ & Eggs pasteurised & 0.00238 & $\mathrm{~kg}$ & 5.99 & 0.0142562 \\
\hline $\mathrm{RM}$ & Salt & 0.00068 & $\mathrm{~kg}$ & 0.13 & 0.0000884 \\
\hline $\mathrm{RM}$ & Water & 0.13328 & $\mathrm{~L}$ & 0.0016 & 0.000213248 \\
\hline $\mathrm{RM}$ & Butter & 0.00238 & $\mathrm{~kg}$ & 1.9437 & 0.004626006 \\
\hline $\mathrm{RM}$ & Whey powder & 0.00238 & $\mathrm{~kg}$ & 1.0644 & 0.002533272 \\
\hline $\mathrm{RM}$ & Transport lorry (raw materials to manufacturer) & 24.684 & $\mathrm{~kg}^{*} \mathrm{~km}$ & 0.00003 & 0.00074052 \\
\hline MA & Electricity (manufacturing milk chocolate) & 0.176616 & MJ & 0.022 & 0.003885552 \\
\hline MA & Electricity (manufacturing wafers) & 0.26384 & MJ & 0.022 & 0.00580448 \\
\hline MA & Gas [manufacturing wafers] & 1.4144 & MJ & 0.0054 & 0.00763776 \\
\hline
\end{tabular}


Table S2 continued

\begin{tabular}{|c|c|c|c|c|c|}
\hline $\begin{array}{l}\text { Chocolate } \\
\text { countlines }\end{array}$ & Activities & $\begin{array}{r}\text { Value per functional unit } \\
(1 \mathrm{~kg} \text { of product) }\end{array}$ & Unit & Unit price $(£)$ & Total cost $(£)$ \\
\hline MA & Electricity (final production line) & 1.635 & MJ & 0.022 & 0.03597 \\
\hline MA & Ammonia & 0.00021 & & 0.33 & 0.0000693 \\
\hline MA & Wastewater & 0.5 & $\mathrm{~L}$ & 0.0013 & 0.00065 \\
\hline MA & Water & 0.5 & $\mathrm{~L}$ & 0.0016 & 0.0008 \\
\hline PA & Aluminium & 0.0253 & $\mathrm{~kg}$ & 1.22 & 0.030866 \\
\hline PA & Cardboard secondary packaging & 0.0566 & $\mathrm{~kg}$ & 0.14 & 0.007924 \\
\hline TR & Transport lorry (packaging to manufacturer) & 12.29 & $\mathrm{~kg}^{*} \mathrm{~km}$ & 0.00003 & 0.0003687 \\
\hline DC & Water & 0.00374 & L & 0.0016 & 0.000005984 \\
\hline TR & Transport lorry (manufacturer to distribution centre) & 150 & $\mathrm{~kg}^{*} \mathrm{~km}$ & 0.00003 & 0.0045 \\
\hline DC & Electricity & 0.00000111 & MJ & 0.022 & 2.442E-08 \\
\hline DC & Wastewater & 0.00374 & $\mathrm{~L}$ & 0.0013 & 0.000004862 \\
\hline DC & LDPE tertiary packaging & 0.00047 & $\mathrm{~kg}$ & 1.57 & 0.0007379 \\
\hline TR & Transport lorry (packaging to distribution centre) & 0.0705 & $\mathrm{~kg}^{*} \mathrm{~km}$ & 0.00003 & 0.000002115 \\
\hline PA & Plastic bags 1 bag weight $0.0075 \mathrm{~kg}$ and costs $5 p$ & 0.0025 & $\mathrm{~kg}$ & 6.6 & 0.0165 \\
\hline RE & Water & 1.12 & $\mathrm{~L}$ & 0.0016 & 0.001792 \\
\hline $\mathrm{RE}$ & Wastewater & 0.000443 & L & 0.0013 & 5.759E-07 \\
\hline TR & Transport lorry (distribution centre to retailer) & 50 & $\mathrm{~kg}^{*} \mathrm{~km}$ & 0.00003 & 0.0015 \\
\hline RE & Waste to recycling (secondary packaging) & 0.048959 & $\mathrm{~kg}$ & 0.06 & 0.00293754 \\
\hline RE & Waste to energy [secondary packaging] & 0.007641 & $\mathrm{~kg}$ & 0.1 & 0.0007641 \\
\hline S & Recycled corrugated board savings & -0.0440631 & $\mathrm{~kg}$ & 0.14 & -0.006168834 \\
\hline $\mathrm{S}$ & Energy from thermal treatment [secondary packaging] & -0.04752702 & MJ & 0.022 & -0.001045594 \\
\hline RE & Waste to energy (tertiary packaging) & 0.00047 & $\mathrm{~kg}$ & 0.99 & 0.0004653 \\
\hline S & Energy from thermal treatment [tertiary packaging] & -0.0106596 & MJ & 0.022 & -0.000234511 \\
\hline TR & Consumers' car $[\mathrm{km}]$ & 0.135 & $\mathrm{~km}$ & 0.12 & 0.0162 \\
\hline $\mathrm{CO}$ & Waste to landfill [plastic bags] & 0.00145 & $\mathrm{~kg}$ & 0.1 & 0.000145 \\
\hline $\mathrm{CO}$ & Waste to thermal treatment (plastic bags) & 0.00105 & $\mathrm{~kg}$ & 0.99 & 0.0010395 \\
\hline S & Energy from thermal treatment [plastic bags] & -0.019278 & MJ & 0.022 & -0.000424116 \\
\hline EOL & Waste to recycling plant (Primary packaging) & 0.0147246 & $\mathrm{~kg}$ & 0.06 & 0.000883476 \\
\hline EOL & Waste to Landfill (primary packaging) & 0.0105754 & $\mathrm{~kg}$ & 0.1 & 0.00105754 \\
\hline S & Saving from recycling (primary packaging) & -0.0147246 & $\mathrm{~kg}$ & 1.22 & -0.017964012 \\
\hline
\end{tabular}


Table S2 continued

\begin{tabular}{|c|c|c|c|c|c|}
\hline $\begin{array}{l}\text { Chocolates in } \\
\text { bag }\end{array}$ & Activities & $\begin{array}{l}\text { Value per functional unit } \\
\text { ( } 1 \mathrm{~kg} \text { of product })\end{array}$ & Unit & Unit price $(£)$ & Total cost $(£)$ \\
\hline RM & Sugar & 0.3212 & $\mathrm{~kg}$ & 0.37 & 0.118844 \\
\hline RM & Palm oil & 0.0365 & $\mathrm{~kg}$ & 0.3698 & 0.0134977 \\
\hline RM & Cocoa butter & 0.1241 & $\mathrm{~kg}$ & 2.114 & 0.2623474 \\
\hline RM & Cocoa liquor & 0.073 & $\mathrm{~kg}$ & 2.6507 & 0.1935011 \\
\hline RM & Milk powder & 0.1752 & $\mathrm{~kg}$ & 2.185 & 0.382812 \\
\hline TR & Transport lorry (raw materials to manufacturer) & 53.29 & $\mathrm{~kg}^{*} \mathrm{~km}$ & 0.00003 & 0.0015987 \\
\hline TR & Transport ship (raw materials to manufacturer & 578.89 & $\mathrm{~kg}^{*} \mathrm{~km}$ & $5.00 \mathrm{E}-08$ & $2.89445 \mathrm{E}-05$ \\
\hline RM & Sugar & 0.0481 & $\mathrm{~kg}$ & 0.37 & 0.017797 \\
\hline RM & Milk powder & 0.0429 & $\mathrm{~kg}$ & 2.185 & 0.0937365 \\
\hline RM & Cocoa butter & 0.039 & $\mathrm{~kg}$ & 2.114 & 0.082446 \\
\hline TR & Transport lorry (raw materials to manufacturer) & 8.58 & $\mathrm{~kg}^{*} \mathrm{~km}$ & 0.00003 & 0.0002574 \\
\hline RM & Flour white & 0.02171 & $\mathrm{~kg}$ & 0.936 & 0.02032056 \\
\hline RM & Milk powder & 0.04329 & $\mathrm{~kg}$ & 2.185 & 0.09458865 \\
\hline RM & Starch & 0.02171 & $\mathrm{~kg}$ & 1.12 & 0.0243152 \\
\hline RM & Sugar & 0.04329 & $\mathrm{~kg}$ & 0.37 & 0.0160173 \\
\hline TR & $\begin{array}{l}\text { Transport lorry (raw materials to manufacturer) } \\
\text { Electricity [manufacturing milk chocolate until }\end{array}$ & 17.342 & $\mathrm{~kg}^{*} \mathrm{~km}$ & 0.00003 & 0.00052026 \\
\hline MA & tempering] & 0.195348 & MJ & 0.022 & 0.004297656 \\
\hline MA & Electricity [manufacturing white chocolate] & 0.021398 & MJ & 0.022 & 0.000470756 \\
\hline MA & Electricity [Manufacturing malted milk powder] & 0.00351 & MJ & 0.022 & 0.00007722 \\
\hline MA & Electricity [manufacturing maltesers centre] & 0.054106 & MJ & 0.022 & 0.001190332 \\
\hline MA & Electricity [manufacturing chocolate in bags] & 1.372 & MJ & 0.022 & 0.030184 \\
\hline MA & Ammonia & 0.00021 & $\mathrm{~kg}$ & 0.33 & 0.0000693 \\
\hline MA & Wastewater & 0.5 & $\mathrm{~L}$ & 0.0013 & 0.00065 \\
\hline MA & Water & 0.5 & $\mathrm{~L}$ & 0.0016 & 0.0008 \\
\hline PA & Aluminium & 0.0398 & $\mathrm{~kg}$ & 1.22 & 0.048556 \\
\hline PA & Cardboard secondary packaging & 0.137 & $\mathrm{~kg}$ & 0.14 & 0.01918 \\
\hline TR & Transport lorry (packaging to manufacturer) & 26.57 & $\mathrm{~kg}^{*} \mathrm{~km}$ & 0.00003 & 0.0007971 \\
\hline DC & Water & 0.0116 & $\mathrm{~L}$ & 0.0016 & 0.00001856 \\
\hline TR & Transport lorry (manufacturer to distribution centre) & 150 & $\mathrm{~kg}^{*} \mathrm{~km}$ & 0.00003 & 0.0045 \\
\hline DC & Electricity & 0.00000343 & MJ & 0.022 & $7.546 \mathrm{E}-08$ \\
\hline DC & Wastewater & 0.0116 & $\mathrm{~L}$ & 0.0013 & 0.00001508 \\
\hline DC & LDPE tertiary packaging & 0.00047 & $\mathrm{~kg}$ & 1.57 & 0.0007379 \\
\hline
\end{tabular}


Table S2 continued

\begin{tabular}{|c|c|c|c|c|c|}
\hline $\begin{array}{l}\text { Chocolates in } \\
\text { bag }\end{array}$ & Activities & $\begin{array}{r}\text { Value per functional unit } \\
(1 \mathrm{~kg} \text { of product })\end{array}$ & Unit & Unit price $(£)$ & Total cost $(£)$ \\
\hline TR & Transport lorry (packaging to distribution centre) & 0.0705 & $\mathrm{~kg}^{*} \mathrm{~km}$ & 0.00003 & 0.000002115 \\
\hline PA & Plastic bags 1 bag weight $0.0075 \mathrm{~kg}$ and costs $5 p$ & 0.0035 & $\mathrm{~kg}$ & 6.6 & 0.0231 \\
\hline RE & Water & 3.48 & $\mathrm{~L}$ & 0.0016 & 0.005568 \\
\hline RE & Electricity & 0.00137 & MJ & 0.022 & 0.00003014 \\
\hline RE & Wastewater & 3.48 & $\mathrm{~L}$ & 0.0013 & 0.004524 \\
\hline TR & Transport lorry (distribution centre to retailer) & 50 & $\mathrm{~kg}^{*} \mathrm{~km}$ & 0.00003 & 0.0015 \\
\hline RE & Waste to recycling (secondary packaging) & 0.118505 & $\mathrm{~kg}$ & 0.06 & 0.0071103 \\
\hline RE & Waste to energy [secondary packaging] & 0.018495 & $\mathrm{~kg}$ & 0.1 & 0.0018495 \\
\hline S & Recycled corrugated board savings & -0.1066545 & $\mathrm{~kg}$ & 0.14 & -0.01493163 \\
\hline S & Energy from thermal treatment (secondary packaging) & -0.1150389 & MJ & 0.022 & -0.002530856 \\
\hline RE & Waste to energy (tertiary packaging) & 0.00047 & $\mathrm{~kg}$ & 0.99 & 0.0004653 \\
\hline S & Energy from thermal treatment (tertiary packaging] & -0.0106596 & MJ & 0.022 & -0.000234511 \\
\hline TR & Consumer's car & 0.135 & $\mathrm{~km}$ & 0.12 & 0.0162 \\
\hline $\mathrm{CO}$ & Waste to landfill (plastic bags) & 0.00203 & $\mathrm{~kg}$ & 0.1 & 0.000203 \\
\hline $\mathrm{CO}$ & Waste to thermal treatment (plastic bags) & 0.00147 & $\mathrm{~kg}$ & 0.99 & 0.0014553 \\
\hline S & Energy from thermal treatment (plastic bags) & -0.0269892 & MJ & 0.022 & -0.000593762 \\
\hline EOL & Waste to recycling plant (primary packaging) & 0.0231636 & $\mathrm{~kg}$ & 0.06 & 0.001389816 \\
\hline EOL & Waste to Landfill (primary packaging) & 0.0166364 & $\mathrm{~kg}$ & 0.1 & 0.00166364 \\
\hline S & Saving for recycling (primary packaging) & -0.0231636 & $\mathrm{~kg}$ & 1.22 & -0.028259592 \\
\hline $\begin{array}{l}\text { Vanilla regular } \\
\text { Ice cream }\end{array}$ & Activities & $\begin{array}{l}\text { Value per functional unit } \\
\text { (1 kg of product) }\end{array}$ & Unit & Unit price $(£)$ & Total cost $(£)$ \\
\hline RM & Sugar & 0.15 & $\mathrm{~kg}$ & 0.37 & 0.0555 \\
\hline RM & Vanillin & 0.000034 & $\mathrm{~kg}$ & 11.97 & 0.00040698 \\
\hline RM & Raw milk & 1.56 & $\mathrm{~kg}$ & 0.2444 & 0.381264 \\
\hline TR & Transport lorry (raw materials to manufacturer) & 157 & $\mathrm{~kg}^{*} \mathrm{~km}$ & 0.00003 & 0.00471 \\
\hline MA & Electricity (manufacturing milk pre-processing) & 0.26995 & MJ & 0.022 & 0.0059389 \\
\hline MA & Steam (milk pre-processing) & 0.2551 & MJ & 0.034 & 0.0086734 \\
\hline MA & Ammonia & $6.45 \mathrm{E}-08$ & & 0.33 & 2.1285E-08 \\
\hline MA & Water & 1.538 & $L$ & 0.0016 & 0.0024608 \\
\hline MA & Wastewater & 1.3613 & $\mathrm{~L}$ & 0.0013 & 0.00176969 \\
\hline MA & Sodium hydroxide & 0.00102 & $\mathrm{~kg}$ & 0.416 & 0.00042432 \\
\hline MA & Nitric acid & 0.00049 & $\mathrm{~kg}$ & 0.141 & 0.00006909 \\
\hline
\end{tabular}


Table S2 continued

\begin{tabular}{|c|c|c|c|c|c|}
\hline $\begin{array}{l}\text { Vanilla regular } \\
\text { ice cream }\end{array}$ & Activities & $\begin{array}{r}\text { Value per functional unit } \\
\text { ( } 1 \mathrm{~kg} \text { of product) }\end{array}$ & Unit & Unit price $(£)$ & Total cost $(£)$ \\
\hline MA & Electricity (manufacturing ice cream) & 3.3713 & MJ & 0.022 & 0.0741686 \\
\hline MA & Steam (ice cream manufacturing) & 0.2365 & & 0.034 & 0.008041 \\
\hline MA & Ammonia & 0.00543 & $\mathrm{~kg}$ & 0.33 & 0.0017919 \\
\hline MA & light fuel & 0.034 & $\mathrm{~L}$ & 1.2 & 0.0408 \\
\hline PA & Polypropylene & 0.075 & $\mathrm{~kg}$ & 1.69 & 0.12675 \\
\hline PA & Low density polyethylene film & 0.00047 & $\mathrm{~kg}$ & 1.57 & 0.0007379 \\
\hline PA & Cardboard secondary packaging & 0.033 & $\mathrm{~kg}$ & 0.14 & 0.00462 \\
\hline TR & Transport lorry (packaging to manufacturer) & 10.8 & $\mathrm{~kg}^{*} \mathrm{~km}$ & 0.00003 & 0.000324 \\
\hline RE & Electricity & 2 & MJ & 0.022 & 0.044 \\
\hline TR & Transport lorry (manufacturer to retailer) & 100 & $\mathrm{~kg}^{*} \mathrm{~km}$ & 0.00003 & 0.003 \\
\hline RE & Waste to recycling (secondary packaging) & 0.028545 & $\mathrm{~kg}$ & 0.06 & 0.0017127 \\
\hline RE & Waste to energy (secondary packaging) & 0.004455 & $\mathrm{~kg}$ & 0.1 & 0.0004455 \\
\hline S & Recycled corrugated board savings & -0.0256905 & $\mathrm{~kg}$ & 0.14 & -0.00359667 \\
\hline S & Energy from thermal treatment (secondary packaging) & -0.00277101 & MJ & 0.0684 & -0.000189537 \\
\hline RE & Waste to energy (tertiary packaging) & 0.00047 & $\mathrm{~kg}$ & 0.99 & 0.0004653 \\
\hline S & Energy from thermal treatment (tertiary packaging) & -0.0106596 & MJ & 0.022 & -0.000234511 \\
\hline TR & Diesel & 0.00082 & $\mathrm{~L}$ & 1.2 & 0.000984 \\
\hline RE & Refrigerant R134a & 0.0005176 & $\mathrm{~kg}$ & 12.8 & 0.00662528 \\
\hline PA & Plastic bags 1 bag weight $0.0075 \mathrm{~kg}$ and costs $5 p$ & 0.025 & $\mathrm{~kg}$ & 6.6 & 0.165 \\
\hline TR & Consumer's car & 0.135 & $\mathrm{~km}$ & 0.12 & 0.0162 \\
\hline $\mathrm{CO}$ & Refrigerant R134a & 0.000000084 & $\mathrm{~kg}$ & 12.8 & $1.0752 \mathrm{E}-06$ \\
\hline $\mathrm{CO}$ & Detergent & 0.0016 & $\mathrm{~kg}$ & 6.65 & 0.01064 \\
\hline $\mathrm{CO}$ & Electricity & 0.2242 & MJ & 0.1519 & 0.03405598 \\
\hline $\mathrm{CO}$ & Water & 0.0722 & $\mathrm{~L}$ & 0.0016 & 0.00011552 \\
\hline $\mathrm{CO}$ & Wastewater & 0.272 & $\mathrm{~L}$ & 0.0013 & 0.0003536 \\
\hline $\mathrm{CO}$ & Waste to landfill (plastic bags) & 0.0145 & $\mathrm{~kg}$ & 0.1 & 0.00145 \\
\hline $\mathrm{CO}$ & Waste to thermal treatment (plastic bags) & 0.0105 & $\mathrm{~kg}$ & 0.99 & 0.010395 \\
\hline S & Energy from thermal treatment (plastic bags) & -0.19278 & $\mathrm{~kg}$ & 0.022 & -0.00424116 \\
\hline EOL & Waste to landfill (primary packaging) & 0.0435 & $\mathrm{~kg}$ & 0.1 & 0.00435 \\
\hline EOL & Waste to thermal treatment (primary packaging) & 0.0315 & $\mathrm{~kg}$ & 0.99 & 0.031185 \\
\hline S & Energy from thermal treatment (primary packaging) & -0.57834 & MJ & 0.022 & -0.01272348 \\
\hline
\end{tabular}


Table S2 continued

\begin{tabular}{|c|c|c|c|c|c|}
\hline $\begin{array}{l}\text { Chocolate } \\
\text { regular } \\
\text { Ice cream }\end{array}$ & Activities & $\begin{array}{l}\text { Value per functional unit } \\
\text { ( } 1 \mathrm{~kg} \text { of product })\end{array}$ & Unit & Unit price $(£)$ & Total cost $(£)$ \\
\hline $\mathrm{RM}$ & Sugar & 0.16 & $\mathrm{~kg}$ & 0.37 & 0.0592 \\
\hline $\mathrm{RM}$ & Cocoa powder & 0.03 & $\mathrm{k}$ & 2.8471 & 0.085413 \\
\hline $\mathrm{RM}$ & Raw milk & 1.5 & $\mathrm{~kg}$ & 0.2444 & 0.3666 \\
\hline TR & Transport lorry (raw materials to manufacturing) & 151 & $\mathrm{~kg}^{*} \mathrm{~km}$ & 0.00003 & 0.00453 \\
\hline MA & Electricity (manufacturing milk pre-processing) & 0.22966 & MJ & 0.022 & 0.00505252 \\
\hline MA & Steam (milk pre-processing) & 0.3281 & MJ & 0.034 & 0.0111554 \\
\hline MA & Ammonia & 6.07E-08 & & 0.33 & $2.0031 \mathrm{E}-08$ \\
\hline MA & Water & 1.634 & $\mathrm{~L}$ & 0.0016 & 0.0026144 \\
\hline MA & Wastewater & 1.28123 & $\mathrm{~L}$ & 0.0013 & 0.001665599 \\
\hline MA & Sodium hydroxide & 0.000961 & $\mathrm{~kg}$ & 0.416 & 0.000399776 \\
\hline MA & Nitric acid & 0.000461 & $\mathrm{~kg}$ & 0.141 & 0.000065001 \\
\hline MA & Electricity (manufacturing ice cream) & 3.1913 & MJ & 0.022 & 0.0702086 \\
\hline MA & Steam (ice cream manufacturing) & 0.2365 & MJ & 0.034 & 0.008041 \\
\hline MA & Ammonia & 0.005604 & & 0.33 & 0.00184932 \\
\hline MA & light fuel & 0.034 & $\mathrm{~L}$ & 1.2 & 0.0408 \\
\hline PA & Polypropylene & 0.075 & $\mathrm{~kg}$ & 1.69 & 0.12675 \\
\hline PA & Low density polyethylene film & 0.00047 & $\mathrm{~kg}$ & 1.57 & 0.0007379 \\
\hline PA & Cardboard secondary packaging & 0.033 & $\mathrm{~kg}$ & 0.14 & 0.00462 \\
\hline TR & Transport lorry (packaging to manufacturer) & 10.8 & $\mathrm{~kg}^{*} \mathrm{~km}$ & 0.00003 & 0.000324 \\
\hline $\mathrm{RE}$ & Electricity & 2 & MJ & 0.022 & 0.044 \\
\hline TR & Transport lorry (manufacturer to retailer) & 100 & $\mathrm{~kg}^{\star} \mathrm{km}$ & 0.00003 & 0.003 \\
\hline RE & Waste to recycling (secondary packaging) & 0.028545 & $\mathrm{~kg}$ & 0.06 & 0.0017127 \\
\hline $\mathrm{RE}$ & Waste to energy (secondary packaging) & 0.004455 & $\mathrm{~kg}$ & 0.1 & 0.0004455 \\
\hline S & Recycled corrugated board savings & -0.0256905 & $\mathrm{~kg}$ & 0.14 & -0.00359667 \\
\hline S & Energy from thermal treatment (secondary packaging) & -0.0277101 & MJ & 0.0684 & -0.001895371 \\
\hline $\mathrm{RE}$ & Waste to energy (tertiary packaging) & 0.00047 & $\mathrm{~kg}$ & 0.99 & 0.0004653 \\
\hline S & Energy from thermal treatment (tertiary packaging) & -0.0106596 & $\mathrm{~kg}$ & 0.022 & -0.000234511 \\
\hline TR & Diesel & 0.00082 & $\mathrm{~L}$ & 1.2 & 0.000984 \\
\hline $\mathrm{RE}$ & Refrigerant $\mathrm{R} 134 \mathrm{a}$ & 0.0005176 & $\mathrm{~kg}$ & 12.8 & 0.00662528 \\
\hline PA & Plastic bags 1 bag weight $0.0075 \mathrm{~kg}$ and costs $5 p$ & 0.025 & $\mathrm{~kg}$ & 6.6 & 0.165 \\
\hline TR & Consumer's car & 0.135 & $\mathrm{~km}$ & 0.12 & 0.0162 \\
\hline $\mathrm{CO}$ & Refrigerant R134a & 0.000000084 & $\mathrm{~km}$ & 12.8 & $1.0752 \mathrm{E}-06$ \\
\hline $\mathrm{CO}$ & Detergent & 0.0016 & $\mathrm{~kg}$ & 6.65 & 0.01064 \\
\hline $\mathrm{CO}$ & Electricity & 0.2242 & MJ & 0.1519 & 0.03405598 \\
\hline $\mathrm{CO}$ & Water & 0.0722 & $\mathrm{~L}$ & 0.0016 & 0.00011552 \\
\hline
\end{tabular}


Table S2 continued

\begin{tabular}{|c|c|c|c|c|c|}
\hline $\begin{array}{l}\text { Chocolate } \\
\text { regular } \\
\text { Ice cream }\end{array}$ & Activities & $\begin{array}{r}\text { Value per functional unit } \\
\text { ( } 1 \mathrm{~kg} \text { of product) }\end{array}$ & Unit & Unit price (£) & Total cost $(£)$ \\
\hline $\mathrm{CO}$ & Wastewater & 0.272 & $\mathrm{~L}$ & 0.0013 & 0.0003536 \\
\hline $\mathrm{CO}$ & Waste to landfill (plastic bags) & 0.0145 & $\mathrm{~kg}$ & 0.1 & 0.00145 \\
\hline $\mathrm{CO}$ & Waste to thermal treatment (plastic bags) & 0.0105 & $\mathrm{~kg}$ & 0.99 & 0.010395 \\
\hline S & Energy from thermal treatment (plastic bags) & -0.19278 & MJ & 0.022 & -0.00424116 \\
\hline EOL & Waste to landfill (primary packaging) & 0.0435 & $\mathrm{~kg}$ & 0.1 & 0.00435 \\
\hline EOL & Waste to thermal treatment (primary packaging) & 0.0315 & $\mathrm{~kg}$ & 0.99 & 0.031185 \\
\hline S & Energy from thermal treatment (primary packaging) & -0.57834 & $\mathrm{~kg}$ & 0.022 & -0.01272348 \\
\hline $\begin{array}{l}\text { Vanilla } \\
\text { premium } \\
\text { ice cream }\end{array}$ & Activities & $\begin{array}{l}\text { Value per functional unit } \\
\text { (1 kg of product) }\end{array}$ & Unit & Unit price $(£)$ & Total cost $(£)$ \\
\hline RM & Sugar & 0.17 & $\mathrm{~kg}$ & 0.37 & 0.0629 \\
\hline RM & Vanilla extract & 0.000034 & $\mathrm{~kg}$ & 155 & 0.00527 \\
\hline RM & Egg yolk & 0.014 & $\mathrm{~kg}$ & 10.95 & 0.1533 \\
\hline RM & Raw milk & 1.63 & $\mathrm{~kg}$ & 0.2444 & 0.398372 \\
\hline TR & Transport lorry (raw materials to manufacturer) & 168.4034 & $\mathrm{~kg}^{*} \mathrm{~km}$ & 0.00003 & 0.005052102 \\
\hline MA & Electricity (manufacturing milk pre-processing) & 0.25382 & MJ & 0.022 & 0.00558404 \\
\hline MA & Steam (milk pre-processing) & 0.1631 & MJ & 0.034 & 0.0055454 \\
\hline MA & Ammonia & 6.87E-08 & & 0.33 & $2.2671 \mathrm{E}-08$ \\
\hline MA & Water & 1.844 & $\mathrm{~L}$ & 0.0016 & 0.0029504 \\
\hline MA & Wastewater & 1.45139 & $\mathrm{~L}$ & 0.0013 & 0.001886807 \\
\hline MA & Sodium hydroxide & 0.00109 & $\mathrm{~kg}$ & 0.416 & 0.00045344 \\
\hline MA & Nitric acid & 0.000521 & $\mathrm{~kg}$ & 0.141 & 0.000073461 \\
\hline MA & Electricity (manufacturing ice cream) & 3.3713 & MJ & 0.022 & 0.0741686 \\
\hline MA & Steam (ice cream manufacturing) & 0.2365 & MJ & 0.034 & 0.008041 \\
\hline MA & Ammonia & 0.005577 & & 0.33 & 0.00184041 \\
\hline MA & light fuel & 0.034 & $\mathrm{~L}$ & 1.2 & 0.0408 \\
\hline PA & Polypropylene & 0.075 & $\mathrm{~kg}$ & 1.69 & 0.12675 \\
\hline PA & Low density polyethylene film & 0.00047 & $\mathrm{~kg}$ & 1.57 & 0.0007379 \\
\hline PA & Cardboard secondary packaging & 0.033 & $\mathrm{~kg}$ & 0.14 & 0.00462 \\
\hline TR & Transport lorry (packaging to manufacturer) & 78.3 & $\mathrm{~kg}^{*} \mathrm{~km}$ & 0.00003 & 0.002349 \\
\hline $\mathrm{RE}$ & Electricity & 2 & MJ & 0.022 & 0.044 \\
\hline
\end{tabular}


Table S2 continued

\begin{tabular}{|c|c|c|c|c|c|}
\hline $\begin{array}{l}\text { Vanilla } \\
\text { premium } \\
\text { ice cream }\end{array}$ & Activities & $\begin{array}{r}\text { Value per functional unit } \\
\text { ( } 1 \mathrm{~kg} \text { of product) }\end{array}$ & Unit & Unit price $(£)$ & Total cost $(£)$ \\
\hline TR & Transport lorry (manufacturer to retailer) & 100 & $\mathrm{~kg}^{*} \mathrm{~km}$ & 0.00003 & 0.003 \\
\hline RE & Waste to recycling (secondary packaging) & 0.028545 & $\mathrm{~kg}$ & 0.06 & 0.0017127 \\
\hline RE & Waste to energy (secondary packaging) & 0.004455 & $\mathrm{~kg}$ & 0.1 & 0.0004455 \\
\hline S & Recycled corrugated board savings & -0.0256905 & $\mathrm{~kg}$ & 0.14 & -0.00359667 \\
\hline S & Energy from thermal treatment (secondary packaging) & -0.0277101 & MJ & 0.0684 & -0.001895371 \\
\hline RE & Waste to energy (tertiary packaging) & 0.00047 & $\mathrm{~kg}$ & 0.99 & 0.0004653 \\
\hline S & Energy from thermal treatment (tertiary packaging) & -0.0106596 & $\mathrm{~kg}$ & 0.022 & -0.000234511 \\
\hline TR & Diesel & 0.00082 & $L$ & 1.2 & 0.000984 \\
\hline RE & Refrigerant $\mathrm{R} 134 \mathrm{a}$ & 0.0005176 & $\mathrm{~kg}$ & 12.8 & 0.00662528 \\
\hline PA & Plastic bags 1 bag weight $0.0075 \mathrm{~kg}$ and costs $5 p$ & 0.025 & $\mathrm{~kg}$ & 6.6 & 0.165 \\
\hline TR & Consumer's car & 0.135 & $\mathrm{~km}$ & 0.12 & 0.0162 \\
\hline $\mathrm{CO}$ & Refrigerant R134a & $8.40 \mathrm{E}-08$ & $\mathrm{~kg}$ & 12.8 & $1.0752 E-06$ \\
\hline $\mathrm{CO}$ & Detergent & 0.0016 & $\mathrm{~kg}$ & 6.65 & 0.01064 \\
\hline $\mathrm{CO}$ & Electricity & 0.2242 & MJ & 0.1519 & 0.03405598 \\
\hline $\mathrm{CO}$ & Water & 0.0722 & $\mathrm{~L}$ & 0.0016 & 0.00011552 \\
\hline $\mathrm{CO}$ & Wastewater & 0.272 & $\mathrm{~L}$ & 0.0013 & 0.0003536 \\
\hline $\mathrm{CO}$ & Waste to landfill (plastic bags) & 0.0145 & $\mathrm{~kg}$ & 0.1 & 0.00145 \\
\hline $\mathrm{CO}$ & Waste to thermal treatment (plastic bags) & 0.0105 & $\mathrm{~kg}$ & 0.99 & 0.010395 \\
\hline S & Energy from thermal treatment (plastic bags) & -0.19278 & MJ & 0.022 & -0.00424116 \\
\hline EOL & Waste to landfill (primary packaging) & 0.0435 & $\mathrm{~kg}$ & 0.1 & 0.00435 \\
\hline EOL & Waste to thermal treatment (primary packaging) & 0.0315 & $\mathrm{~kg}$ & 0.99 & 0.031185 \\
\hline S & Energy from thermal treatment (primary packaging) & -0.57834 & MJ & 0.022 & -0.01272348 \\
\hline $\begin{array}{l}\text { Chocolate } \\
\text { premium } \\
\text { Ice cream }\end{array}$ & Activities & $\begin{array}{l}\text { Value per functional unit } \\
\text { ( } 1 \mathrm{~kg} \text { of product) }\end{array}$ & Unit & Unit price $(£)$ & Total cost $(£)$ \\
\hline RM & Sugar & 0.19 & $\mathrm{~kg}$ & 0.37 & 0.0703 \\
\hline RM & Cocoa powder & 0.035 & $\mathrm{~kg}$ & 2.8471 & 0.0996485 \\
\hline $\mathrm{RM}$ & Egg yolk & 0.014 & $\mathrm{~kg}$ & 10.95 & 0.1533 \\
\hline $\mathrm{RM}$ & Raw milk & 1.59 & $\mathrm{~kg}$ & 0.2444 & 0.388596 \\
\hline TR & Transport lorry (raw materials to manufacturer) & 166.9 & $\mathrm{~kg}^{*} \mathrm{~km}$ & 0.00003 & 0.005007 \\
\hline MA & Electricity [manufacturing milk pre-processing] & 0.24569 & MJ & 0.022 & 0.00540518 \\
\hline
\end{tabular}


Table S2 continued

\begin{tabular}{|c|c|c|c|c|c|}
\hline $\begin{array}{l}\text { Chocolate } \\
\text { premium } \\
\text { Ice cream }\end{array}$ & Activities & $\begin{array}{r}\text { Value per functional unit } \\
\text { ( } 1 \mathrm{~kg} \text { of product) }\end{array}$ & Unit & Unit price $(£)$ & Total cost $(£)$ \\
\hline MA & Steam [milk pre-processing] & 0.1616 & MJ & 0.034 & 0.0054944 \\
\hline MA & Ammonia & 6.67E-08 & & 0.33 & 2.2011E-08 \\
\hline MA & Water & 1.792 & $\mathrm{~L}$ & 0.0016 & 0.0028672 \\
\hline MA & Wastewater & 1.40135 & $\mathrm{~L}$ & 0.0013 & 0.001821755 \\
\hline MA & Sodium hydroxide & 0.00105 & $\mathrm{~kg}$ & 0.416 & 0.0004368 \\
\hline MA & Nitric acid & 0.000506 & $\mathrm{~kg}$ & 0.141 & 0.000071346 \\
\hline MA & Electricity [manufacturing ice cream] & 3.3713 & MJ & 0.022 & 0.0741686 \\
\hline MA & Steam [ ice cream manufacturing] & 0.2365 & MJ & 0.034 & 0.008041 \\
\hline MA & Ammonia & 0.005577 & & 0.33 & 0.00184041 \\
\hline MA & light fuel & 0.034 & $\mathrm{~L}$ & 1.2 & 0.0408 \\
\hline PA & Polypropylene & 0.075 & $\mathrm{~kg}$ & 1.69 & 0.12675 \\
\hline PA & Low density polyethylene film & 0.00047 & $\mathrm{~kg}$ & 1.57 & 0.0007379 \\
\hline PA & Cardboard secondary packaging & 0.033 & $\mathrm{~kg}$ & 0.14 & 0.00462 \\
\hline TR & Transport lorry (packaging to manufacturer) & 78.3 & $\mathrm{~kg}^{*} \mathrm{~km}$ & 0.00003 & 0.002349 \\
\hline RE & Electricity & 2 & MJ & 0.022 & 0.044 \\
\hline TR & Transport lorry (manufacturer to retailer) & 100 & $\mathrm{~kg}^{*} \mathrm{~km}$ & 0.00003 & 0.003 \\
\hline RE & Waste to recycling (secondary packaging) & 0.028545 & $\mathrm{~kg}$ & 0.06 & 0.0017127 \\
\hline RE & Waste to energy (secondary packaging) & 0.004455 & $\mathrm{~kg}$ & 0.1 & 0.0004455 \\
\hline $\mathrm{s}$ & Recycled corrugated board savings & -0.0256905 & $\mathrm{~kg}$ & 0.14 & -0.00359667 \\
\hline S & Energy from thermal treatment (secondary packaging) & -0.0277101 & MJ & 0.0684 & -0.001895371 \\
\hline RE & Waste to energy (tertiary packaging) & 0.00047 & $\mathrm{~kg}$ & 0.99 & 0.0004653 \\
\hline $\mathrm{s}$ & Energy from thermal treatment (tertiary packaging) & -0.0106596 & MJ & 0.022 & -0.000234511 \\
\hline TR & Diesel & 0.00082 & $\mathrm{~L}$ & 1.2 & 0.000984 \\
\hline RE & Refrigerant R134a & 0.0005176 & $\mathrm{~kg}$ & 12.8 & 0.00662528 \\
\hline PA & Plastic bags 1 bag weight $0.0075 \mathrm{~kg}$ and costs $5 p$ & 0.025 & $\mathrm{~kg}$ & 6.6 & 0.165 \\
\hline TR & Consumer's car & 0.135 & $\mathrm{~km}$ & 0.12 & 0.0162 \\
\hline $\mathrm{co}$ & Refrigerant R134a & $8.40 \mathrm{E}-08$ & $\mathrm{~kg}$ & 12.8 & $1.0752 \mathrm{E}-06$ \\
\hline $\mathrm{co}$ & Detergent & 0.0016 & $\mathrm{~kg}$ & 6.65 & 0.01064 \\
\hline $\mathrm{CO}$ & Electricity & 0.2242 & MJ & 0.1519 & 0.03405598 \\
\hline $\mathrm{co}$ & Water & 0.0722 & $\mathrm{~L}$ & 0.0016 & 0.00011552 \\
\hline $\mathrm{co}$ & Wastewater & 0.272 & $\mathrm{~L}$ & 0.0013 & 0.0003536 \\
\hline $\mathrm{co}$ & Waste to landfill (plastic bags) & 0.0145 & $\mathrm{~kg}$ & 0.1 & 0.00145 \\
\hline
\end{tabular}


Table S2 continued

\begin{tabular}{|c|c|c|c|c|c|}
\hline $\begin{array}{l}\text { Chocolate } \\
\text { premium } \\
\text { Ice cream }\end{array}$ & Activities & $\begin{array}{r}\text { Value per functional unit } \\
\text { ( } 1 \mathrm{~kg} \text { of product) }\end{array}$ & Unit & Unit price (£) & Total cost $(£)$ \\
\hline $\mathrm{CO}$ & Waste to thermal treatment (plastic bags) & 0.0105 & $\mathrm{~kg}$ & 0.99 & 0.010395 \\
\hline S & Energy from thermal treatment (plastic bags) & -0.19278 & MJ & 0.022 & -0.00424116 \\
\hline EOL & Waste to landfill (primary packaging) & 0.0435 & $\mathrm{~kg}$ & 0.1 & 0.00435 \\
\hline EOL & Waste to thermal treatment (primary packaging) & 0.0315 & $\mathrm{~kg}$ & 0.99 & 0.031185 \\
\hline S & Energy from thermal treatment (primary packaging) & -0.57834 & MJ & 0.022 & -0.01272348 \\
\hline
\end{tabular}

Table S3 Contribution of different life cycle stages to the total life cycle costs (contribution $<1 \%$ excluded)

\begin{tabular}{|c|c|c|c|c|c|c|c|c|c|}
\hline Products & $\begin{array}{r}\text { Raw } \\
\text { materials }\end{array}$ & Manufacturing & Packaging & $\begin{array}{r}\text { Distribution } \\
\text { centre }\end{array}$ & Retail & Consumption & $\begin{array}{r}\text { End-of-life waste } \\
\text { management }\end{array}$ & Transport & Credits \\
\hline \multicolumn{10}{|l|}{ Biscuits } \\
\hline Crackers & $78.8 \%$ & $5.7 \%$ & $11.2 \%$ & & & & & $3.1 \%$ & \\
\hline Low fat/sugar & $84.1 \%$ & $6.4 \%$ & $5.6 \%$ & & & & & $3.4 \%$ & \\
\hline Semi-Sweet & $83.1 \%$ & $6.6 \%$ & $5.7 \%$ & & & & & $3.5 \%$ & \\
\hline Chocolate coated & $85.1 \%$ & $7.3 \%$ & $3.8 \%$ & & & & & $3.3 \%$ & \\
\hline Chocolate cream & $85.9 \%$ & $5.8 \%$ & $3.9 \%$ & & & & & $3.6 \%$ & \\
\hline Vanilla cream & $84.8 \%$ & $6.3 \%$ & $4.3 \%$ & & & & & $3.6 \%$ & \\
\hline \multicolumn{10}{|l|}{ Cakes } \\
\hline Whole cakes & $93.5 \%$ & $1.2 \%$ & $2.2 \%$ & & & & & & \\
\hline Slices & $86.0 \%$ & $2.0 \%$ & $8.0 \%$ & & & & $3.0 \%$ & & \\
\hline Pies & $84.3 \%$ & $4.0 \%$ & $7.0 \%$ & & $1.2 \%$ & & $2.2 \%$ & $2.0 \%$ & $-1.5 \%$ \\
\hline Cupcakes & $80.1 \%$ & $1.7 \%$ & $12.8 \%$ & & $2.2 \%$ & & $3.9 \%$ & $1.5 \%$ & $-3.2 \%$ \\
\hline Cheesecake & $86.5 \%$ & $3.5 \%$ & $4.6 \%$ & & & $1.6 \%$ & $2.2 \%$ & $1.6 \%$ & \\
\hline \multicolumn{10}{|l|}{ Chocolates } \\
\hline Milk chocolate & $94.1 \%$ & $2.2 \%$ & $1.9 \%$ & & & & & $1.8 \%$ & \\
\hline Chocolate & $89.9 \%$ & $4.7 \%$ & $4.8 \%$ & & & & & $2.0 \%$ & $-2.3 \%$ \\
\hline Chocolates in bag & $90.6 \%$ & $2.6 \%$ & $6.2 \%$ & & $1.3 \%$ & & & $1.7 \%$ & $-2.9 \%$ \\
\hline \multicolumn{10}{|l|}{ Ice cream } \\
\hline Vanilla regular & $43.0 \%$ & $14.0 \%$ & $29.0 \%$ & & $5.0 \%$ & $6.0 \%$ & $3.0 \%$ & $2.0 \%$ & $-2.0 \%$ \\
\hline Chocolate regular & $47.0 \%$ & $13.0 \%$ & $27.0 \%$ & & $5.0 \%$ & $5.0 \%$ & $3.0 \%$ & $2.0 \%$ & $-2.0 \%$ \\
\hline Vanilla premium & $51.0 \%$ & $12.0 \%$ & $25.0 \%$ & & $4.0 \%$ & $5.0 \%$ & $3.0 \%$ & $2.0 \%$ & $-2.0 \%$ \\
\hline Chocolate premium & $55.0 \%$ & $11.0 \%$ & $23.0 \%$ & & $4.0 \%$ & $4.0 \%$ & $3.0 \%$ & $2.0 \%$ & $-2.0 \%$ \\
\hline
\end{tabular}


Table S4 Costs, sales prices and value added $(£ / \mathrm{kg})$

\begin{tabular}{|c|c|c|c|c|c|c|c|}
\hline Product category & Product & $\begin{array}{r}\text { Cost to } \\
\text { manufacturer } \\
(\xi / \mathrm{kg}) \\
\end{array}$ & $\begin{array}{r}\text { Cost to retailer } \\
(\xi / \mathbf{k g})\end{array}$ & $\begin{array}{r}\text { Costs to consumer } \\
(\Sigma / \mathbf{k g})\end{array}$ & $\begin{array}{r}\text { Total life cycle } \\
\text { costs }(£ / \mathrm{kg})\end{array}$ & $\begin{array}{r}\text { Sales price } \\
(£ / \mathbf{k g})\end{array}$ & $\begin{array}{r}\text { Value added } \\
(\xi / \mathbf{k g})\end{array}$ \\
\hline \multirow[t]{6}{*}{ Biscuits } & Crackers & 0.844 & 0.857 & 0.904 & 0.908 & 1.3 & 0.443 \\
\hline & Low fat biscuits & 0.760 & 0.774 & 0.812 & 0.808 & 1.5 & 0.726 \\
\hline & Semi-sweet & 0.735 & 0.749 & 0.787 & 0.787 & 1.1 & 0.351 \\
\hline & Chocolate coated & 0.838 & 0.851 & 0.881 & 0.879 & 2 & 1.149 \\
\hline & Chocolate cream & 0.739 & 0.752 & 0.784 & 0.783 & 6.5 & 5.748 \\
\hline & Vanilla cream & 0.674 & 0.685 & 0.717 & 0.717 & 6.4 & 5.715 \\
\hline \multirow[t]{5}{*}{ Cakes } & Whole cakes & 2.534 & 2.556 & 2.601 & 2.640 & 6.8 & 4.244 \\
\hline & Slices & 1.998 & 2.019 & 2.070 & 2.128 & 8 & 5.981 \\
\hline & Pies & 1.423 & 1.448 & 1.494 & 1.517 & 2 & 0.552 \\
\hline & Cupcakes & 1.674 & 1.720 & 1.797 & 1.828 & 13 & 11.280 \\
\hline & Cheese cake & 1.645 & 1.666 & 1.703 & 1.756 & 4.3 & 2.634 \\
\hline \multirow[t]{3}{*}{ Chocolate } & Moulded chocolate & 1.377 & 1.391 & 1.423 & 1.414 & 7.5 & 6.109 \\
\hline & Chocolate countlines & 1.135 & 1.146 & 1.179 & 1.156 & 6 & 4.854 \\
\hline & Chocolate in bags & 1.429 & 1.455 & 1.495 & 1.458 & 8.3 & 6.845 \\
\hline \multirow[t]{4}{*}{ Ice cream } & Vanilla regular & 0.721 & 0.778 & 0.959 & 1.029 & 2 & 1.222 \\
\hline & Chocolate regular & 0.785 & 0.842 & 1.023 & 1.099 & 2 & 1.158 \\
\hline & Vanilla premium & 0.910 & 0.967 & 1.149 & 1.210 & 5 & 4.033 \\
\hline & Chocolate premium & 0.999 & 1.056 & 1.238 & 1.301 & 5 & 3.944 \\
\hline
\end{tabular}


Table S5 Data for uncertainty analysis

\begin{tabular}{|c|c|c|c|c|c|c|c|}
\hline Crackers & Value (-) & Percentile & Value (-) & $\begin{array}{l}\text { Low fat/sugar } \\
\text { biscuits }\end{array}$ & Value (-) & Percentile & Value (-) \\
\hline Minimum & 0.74 & $5 \%$ & 0.81 & Minimum & 0.65 & $5 \%$ & 0.71 \\
\hline Maximum & 1.06 & $10 \%$ & 0.83 & Maximum & 0.96 & $10 \%$ & 0.73 \\
\hline Mean & 0.91 & $15 \%$ & 0.84 & Mean & 0.81 & $15 \%$ & 0.74 \\
\hline Std Dev & 0.06 & $20 \%$ & 0.85 & Std Dev & 0.06 & $20 \%$ & 0.75 \\
\hline Variance & 0.00 & $25 \%$ & 0.86 & Variance & 0.00 & $25 \%$ & 0.76 \\
\hline Skewness & -0.01 & $30 \%$ & 0.87 & Skewness & -0.01 & $30 \%$ & 0.77 \\
\hline Kurtosis & 2.36 & $35 \%$ & 0.88 & Kurtosis & 2.34 & $35 \%$ & 0.78 \\
\hline Median & 0.91 & $40 \%$ & 0.89 & Median & 0.81 & $40 \%$ & 0.79 \\
\hline Mode & 0.91 & $45 \%$ & 0.90 & Mode & 0.82 & $45 \%$ & 0.80 \\
\hline Left $X$ & 0.81 & $50 \%$ & 0.91 & Left $X$ & 0.71 & $50 \%$ & 0.81 \\
\hline Left $P$ & 0.03 & $55 \%$ & 0.92 & Left $P$ & 0.03 & $55 \%$ & 0.82 \\
\hline Right X & 1.00 & $60 \%$ & 0.92 & Right $X$ & 0.90 & $60 \%$ & 0.82 \\
\hline Right P & 0.98 & $65 \%$ & 0.93 & Right $P$ & 0.98 & $65 \%$ & 0.83 \\
\hline Diff $X$ & 0.19 & $70 \%$ & 0.94 & Diff $X$ & 0.19 & $70 \%$ & 0.84 \\
\hline Diff $P$ & 0.95 & $75 \%$ & 0.95 & Diff $P$ & 0.95 & $75 \%$ & 0.85 \\
\hline \#Errors & 0.00 & $80 \%$ & 0.96 & \#Errors & 0.00 & $80 \%$ & 0.86 \\
\hline Filter Min & Off & $85 \%$ & 0.97 & Filter Min & Off & $85 \%$ & 0.87 \\
\hline Filter Max & Off & $90 \%$ & 0.99 & Filter Max & Off & $90 \%$ & 0.89 \\
\hline \#Filtered & 0.00 & $95 \%$ & 1.00 & \#Filtered & 0.00 & $95 \%$ & 0.90 \\
\hline $\begin{array}{l}\text { Semi sweet } \\
\text { biscuits }\end{array}$ & Value (-) & Percentile & Value (-) & $\begin{array}{l}\text { Chocolate coated } \\
\text { Biscuits }\end{array}$ & Value (-) & Percentile & Value (-) \\
\hline Minimum & 0.64 & $5 \%$ & 0.69 & Minimum & 0.76 & $5 \%$ & 0.82 \\
\hline Maximum & 0.92 & $10 \%$ & 0.71 & Maximum & 1.00 & $10 \%$ & 0.83 \\
\hline Mean & 0.78 & $15 \%$ & 0.72 & Mean & 0.88 & $15 \%$ & 0.84 \\
\hline Std Dev & 0.05 & $20 \%$ & 0.73 & Std Dev & 0.04 & $20 \%$ & 0.85 \\
\hline Variance & 0.00 & $25 \%$ & 0.74 & Variance & 0.00 & $25 \%$ & 0.85 \\
\hline Skewness & -0.01 & $30 \%$ & 0.75 & Skewness & 0.00 & $30 \%$ & 0.86 \\
\hline Kurtosis & 2.34 & $35 \%$ & 0.76 & Kurtosis & 2.62 & $35 \%$ & 0.86 \\
\hline Median & 0.78 & $40 \%$ & 0.77 & Median & 0.88 & $40 \%$ & 0.87 \\
\hline Mode & 0.79 & $45 \%$ & 0.78 & Mode & 0.87 & $45 \%$ & 0.87 \\
\hline Left $X$ & 0.69 & $50 \%$ & 0.78 & Left $X$ & 0.82 & $50 \%$ & 0.88 \\
\hline Left $P$ & 0.03 & $55 \%$ & 0.79 & Left $P$ & 0.03 & $55 \%$ & 0.88 \\
\hline
\end{tabular}


Table S5 continued

\begin{tabular}{|c|c|c|c|c|c|c|c|}
\hline $\begin{array}{l}\text { Semi sweet } \\
\text { biscuits }\end{array}$ & Value (-) & Percentile & Value (-) & $\begin{array}{l}\text { Chocolate coated } \\
\text { Biscuits }\end{array}$ & Value (-) & Percentile & Value (-) \\
\hline Right X & 0.87 & $60 \%$ & 0.80 & Right X & 0.94 & $60 \%$ & 0.89 \\
\hline Right P & 0.98 & $65 \%$ & 0.80 & Right P & 0.98 & $65 \%$ & 0.89 \\
\hline Diff $X$ & 0.17 & $70 \%$ & 0.81 & Diff X & 0.11 & $70 \%$ & 0.90 \\
\hline Diff $P$ & 0.95 & $75 \%$ & 0.82 & Diff $P$ & 0.95 & $75 \%$ & 0.90 \\
\hline \#Errors & 0.00 & $80 \%$ & 0.83 & \#Errors & 0.00 & $80 \%$ & 0.91 \\
\hline Filter Min & Off & $85 \%$ & 0.84 & Filter Min & Off & $85 \%$ & 0.92 \\
\hline Filter Max & Off & $90 \%$ & 0.85 & Filter Max & Off & $90 \%$ & 0.93 \\
\hline \#Filtered & 0.00 & $95 \%$ & 0.87 & \#Filtered & 0.00 & $95 \%$ & 0.94 \\
\hline $\begin{array}{l}\text { Chocolate } \\
\text { cream biscuits }\end{array}$ & Value (-) & Percentile & Value (-) & $\begin{array}{l}\text { Vanilla cream } \\
\text { biscuits }\end{array}$ & Value (-) & Percentile & Value (-) \\
\hline Minimum & 0.68 & $5 \%$ & 0.72 & Minimum & 0.61 & $5 \%$ & 0.66 \\
\hline Maximum & 0.90 & $10 \%$ & 0.74 & Maximum & 0.82 & $10 \%$ & 0.67 \\
\hline Mean & 0.78 & $15 \%$ & 0.74 & Mean & 0.72 & $15 \%$ & 0.68 \\
\hline Std Dev & 0.04 & $20 \%$ & 0.75 & Std Dev & 0.04 & $20 \%$ & 0.68 \\
\hline Variance & 0.00 & $25 \%$ & 0.76 & Variance & 0.00 & $25 \%$ & 0.69 \\
\hline Skewness & -0.01 & $30 \%$ & 0.76 & Skewness & -0.01 & $30 \%$ & 0.70 \\
\hline Kurtosis & 2.50 & $35 \%$ & 0.77 & Kurtosis & 2.45 & $35 \%$ & 0.70 \\
\hline Median & 0.78 & $40 \%$ & 0.77 & Median & 0.72 & $40 \%$ & 0.71 \\
\hline Mode & 0.78 & $45 \%$ & 0.78 & Mode & 0.72 & $45 \%$ & 0.71 \\
\hline Left $X$ & 0.72 & $50 \%$ & 0.78 & Left $X$ & 0.66 & $50 \%$ & 0.72 \\
\hline Left P & 0.03 & $55 \%$ & 0.79 & Left P & 0.03 & $55 \%$ & 0.72 \\
\hline Right X & 0.84 & $60 \%$ & 0.79 & Right X & 0.78 & $60 \%$ & 0.73 \\
\hline Right P & 0.98 & $65 \%$ & 0.80 & Right $P$ & 0.98 & $65 \%$ & 0.73 \\
\hline Diff $X$ & 0.12 & $70 \%$ & 0.80 & Diff X & 0.12 & $70 \%$ & 0.74 \\
\hline Diff P & 0.95 & $75 \%$ & 0.81 & Diff $P$ & 0.95 & $75 \%$ & 0.74 \\
\hline \#Errors & 0.00 & $80 \%$ & 0.82 & \#Errors & 0.00 & $80 \%$ & 0.75 \\
\hline Filter Min & Off & $85 \%$ & 0.82 & Filter Min & Off & $85 \%$ & 0.76 \\
\hline Filter Max & Off & $90 \%$ & 0.83 & Filter Max & Off & $90 \%$ & 0.77 \\
\hline \#Filtered & 0.00 & $95 \%$ & 0.84 & \#Filtered & 0.00 & $95 \%$ & 0.78 \\
\hline
\end{tabular}


Table S5: continued

\begin{tabular}{|c|c|c|c|c|c|c|c|}
\hline Whole cakes & Value (-) & Percentile & Value (-) & Cake slices & Value (-) & Percentile & Value (-) \\
\hline Minimum & 2.21 & $5 \%$ & 2.40 & Minimum & 1.81 & $5 \%$ & 1.95 \\
\hline Maximum & 3.09 & $10 \%$ & 2.45 & Maximum & 2.44 & $10 \%$ & 1.98 \\
\hline Mean & 2.64 & $15 \%$ & 2.48 & Mean & 2.13 & $15 \%$ & 2.01 \\
\hline Std Dev & 0.14 & $20 \%$ & 2.51 & Std Dev & 0.11 & $20 \%$ & 2.03 \\
\hline Variance & 0.02 & $25 \%$ & 2.53 & Variance & 0.01 & $25 \%$ & 2.05 \\
\hline Skewness & 0.00 & $30 \%$ & 2.56 & Skewness & -0.01 & $30 \%$ & 2.06 \\
\hline Kurtosis & 2.44 & $35 \%$ & 2.58 & Kurtosis & 2.40 & $35 \%$ & 2.08 \\
\hline Median & 2.64 & $40 \%$ & 2.60 & Median & 2.13 & $40 \%$ & 2.10 \\
\hline Mode & 2.63 & $45 \%$ & 2.62 & Mode & 2.13 & $45 \%$ & 2.11 \\
\hline Left $X$ & 2.40 & $50 \%$ & 2.64 & Left $X$ & 1.95 & $50 \%$ & 2.13 \\
\hline Left $P$ & 0.03 & $55 \%$ & 2.66 & Left $P$ & 0.03 & $55 \%$ & 2.14 \\
\hline Right X & 2.88 & $60 \%$ & 2.68 & Right $X$ & 2.30 & $60 \%$ & 2.16 \\
\hline Right $P$ & 0.98 & $65 \%$ & 2.70 & Right $P$ & 0.98 & $65 \%$ & 2.17 \\
\hline Diff $X$ & 0.47 & $70 \%$ & 2.72 & Diff X & 0.36 & $70 \%$ & 2.19 \\
\hline Diff $P$ & 0.95 & $75 \%$ & 2.75 & Diff $P$ & 0.95 & $75 \%$ & 2.21 \\
\hline \#Errors & 0.00 & $80 \%$ & 2.77 & \#Errors & 0 & $80 \%$ & 2.23 \\
\hline Filter Min & Off & $85 \%$ & 2.80 & Filter Min & Off & $85 \%$ & 2.25 \\
\hline Filter Max & Off & $90 \%$ & 2.83 & Filter Max & Off & $90 \%$ & 2.27 \\
\hline \#Filtered & 0.00 & $95 \%$ & 2.88 & \#Filtered & 0.00 & $95 \%$ & 2.30 \\
\hline Pies & Value (-) & Percentile & Value (-) & Cupcakes & Value (-) & Percentile & Value (-) \\
\hline Minimum & 1.26 & $5 \%$ & 1.38 & Minimum & 1.57 & $5 \%$ & 1.70 \\
\hline Maximum & 1.78 & $10 \%$ & 1.41 & Maximum & 2.07 & $10 \%$ & 1.73 \\
\hline Mean & 1.52 & $15 \%$ & 1.43 & Mean & 1.83 & $15 \%$ & 1.74 \\
\hline Std Dev & 0.08 & $20 \%$ & 1.44 & Std Dev & 0.08 & $20 \%$ & 1.76 \\
\hline Variance & 0.01 & $25 \%$ & 1.46 & Variance & 0.01 & $25 \%$ & 1.77 \\
\hline Skewness & 0.00 & $30 \%$ & 1.47 & Skewness & -0.01 & $30 \%$ & 1.78 \\
\hline Kurtosis & 2.53 & $35 \%$ & 1.48 & Kurtosis & 2.50 & $35 \%$ & 1.80 \\
\hline Median & 1.52 & $40 \%$ & 1.49 & Median & 1.83 & $40 \%$ & 1.81 \\
\hline Mode & 1.51 & $45 \%$ & 1.51 & Mode & 1.85 & $45 \%$ & 1.82 \\
\hline Left $X$ & 1.38 & $50 \%$ & 1.52 & Left $X$ & 1.70 & $50 \%$ & 1.83 \\
\hline Left $P$ & 0.03 & $55 \%$ & 1.53 & Left $P$ & 0.03 & $55 \%$ & 1.84 \\
\hline Right $X$ & 1.66 & $60 \%$ & 1.54 & Right $X$ & 1.95 & $60 \%$ & 1.85 \\
\hline
\end{tabular}


Table S5: continued

\begin{tabular}{|c|c|c|c|c|c|c|c|}
\hline Pies & Value (-) & Percentile & Value (-) & Cupcakes & Value (-) & Percentile & Value (-) \\
\hline Right P & 0.98 & $65 \%$ & 1.55 & Right P & 0.98 & $65 \%$ & 1.86 \\
\hline Diff $X$ & 0.28 & $70 \%$ & 1.56 & Diff X & 0.25 & $70 \%$ & 1.87 \\
\hline Diff $P$ & 0.95 & $75 \%$ & 1.58 & Diff P & 0.95 & $75 \%$ & 1.88 \\
\hline \#Errors & 0.00 & $80 \%$ & 1.59 & \#Errors & 0.00 & $80 \%$ & 1.90 \\
\hline Filter Min & Off & $85 \%$ & 1.61 & Filter Min & Off & $85 \%$ & 1.91 \\
\hline Filter Max & Off & $90 \%$ & 1.63 & Filter Max & Off & $90 \%$ & 1.93 \\
\hline \#Filtered & 0.00 & $95 \%$ & 1.66 & \#Filtered & 0.00 & $95 \%$ & 1.95 \\
\hline Cheesecake & Value (-) & Percentile & Value (-) & $\begin{array}{l}\text { Moulded } \\
\text { chocolates }\end{array}$ & Value (-) & Percentile & Value (-) \\
\hline Minimum & 1.52 & $5 \%$ & 1.64 & Minimum & 1.17 & $5 \%$ & 1.30 \\
\hline Maximum & 2.03 & $10 \%$ & 1.66 & Maximum & 1.66 & $10 \%$ & 1.33 \\
\hline Mean & 1.76 & $15 \%$ & 1.68 & Mean & 1.41 & $15 \%$ & 1.34 \\
\hline Std Dev & 0.07 & $20 \%$ & 1.70 & Std Dev & 0.07 & $20 \%$ & 1.36 \\
\hline Variance & 0.01 & $25 \%$ & 1.71 & Variance & 0.00 & $25 \%$ & 1.37 \\
\hline Skewness & -0.01 & $30 \%$ & 1.72 & Skewness & -0.03 & $30 \%$ & 1.38 \\
\hline Kurtosis & 2.79 & $35 \%$ & 1.73 & Kurtosis & 2.77 & $35 \%$ & 1.39 \\
\hline Median & 1.76 & $40 \%$ & 1.74 & Median & 1.41 & $40 \%$ & 1.40 \\
\hline Mode & 1.77 & $45 \%$ & 1.75 & Mode & 1.41 & $45 \%$ & 1.41 \\
\hline Left $X$ & 1.64 & $50 \%$ & 1.76 & Left $X$ & 1.30 & $50 \%$ & 1.41 \\
\hline Left $P$ & 0.03 & $55 \%$ & 1.77 & Left P & 0.03 & $55 \%$ & 1.42 \\
\hline Right X & 1.87 & $60 \%$ & 1.78 & Right $X$ & 1.52 & $60 \%$ & 1.43 \\
\hline Right P & 0.98 & $65 \%$ & 1.78 & Right $P$ & 0.98 & $65 \%$ & 1.44 \\
\hline Diff X & 0.24 & $70 \%$ & 1.79 & Diff X & 0.22 & $70 \%$ & 1.45 \\
\hline Diff P & 0.95 & $75 \%$ & 1.81 & Diff $P$ & 0.95 & $75 \%$ & 1.46 \\
\hline \#Errors & 0.00 & $80 \%$ & 1.82 & \#Errors & 0.00 & $80 \%$ & 1.47 \\
\hline Filter Min & Off & $85 \%$ & 1.83 & Filter Min & Off & $85 \%$ & 1.48 \\
\hline Filter Max & Off & $90 \%$ & 1.85 & Filter Max & Off & $90 \%$ & 1.50 \\
\hline \#Filtered & 0.00 & $95 \%$ & 1.87 & \#Filtered & 0.00 & $95 \%$ & 1.52 \\
\hline
\end{tabular}


Table S5: continued

\begin{tabular}{|c|c|c|c|c|c|c|c|}
\hline $\begin{array}{l}\text { Chocolate } \\
\text { countlines }\end{array}$ & Value (-) & Percentile & Value (-) & $\begin{array}{l}\text { Chocolates in } \\
\text { bag }\end{array}$ & Value (-) & Percentile & Value (-) \\
\hline Minimum & 0.98 & $5 \%$ & 1.08 & Minimum & 1.26 & $5 \%$ & 1.37 \\
\hline Maximum & 1.31 & $10 \%$ & 1.10 & Maximum & 1.63 & $10 \%$ & 1.39 \\
\hline Mean & 1.16 & $15 \%$ & 1.11 & Mean & 1.46 & $15 \%$ & 1.40 \\
\hline Std Dev & 0.05 & $20 \%$ & 1.12 & Std Dev & 0.05 & $20 \%$ & 1.41 \\
\hline Variance & 0.00 & $25 \%$ & 1.12 & Variance & 0.00 & $25 \%$ & 1.42 \\
\hline Skewness & 0.01 & $30 \%$ & 1.13 & Skewness & -0.03 & $30 \%$ & 1.43 \\
\hline Kurtosis & 2.75 & $35 \%$ & 1.14 & Kurtosis & 2.79 & $35 \%$ & 1.44 \\
\hline Median & 1.16 & $40 \%$ & 1.14 & Median & 1.46 & $40 \%$ & 1.44 \\
\hline Mode & 1.17 & $45 \%$ & 1.15 & Mode & 1.46 & $45 \%$ & 1.45 \\
\hline Left $X$ & 1.08 & $50 \%$ & 1.16 & Left $X$ & 1.37 & $50 \%$ & 1.46 \\
\hline Left $P$ & 0.03 & $55 \%$ & 1.16 & Left $P$ & 0.03 & $55 \%$ & 1.46 \\
\hline Right X & 1.23 & $60 \%$ & 1.17 & Right X & 1.54 & $60 \%$ & 1.47 \\
\hline Right $P$ & 0.98 & $65 \%$ & 1.17 & Right $P$ & 0.98 & $65 \%$ & 1.48 \\
\hline Diff $X$ & 0.15 & $70 \%$ & 1.18 & Diff X & 0.17 & $70 \%$ & 1.49 \\
\hline Diff $P$ & 0.95 & $75 \%$ & 1.19 & Diff P & 0.95 & $75 \%$ & 1.49 \\
\hline \#Errors & 0.00 & $80 \%$ & 1.20 & \#Errors & 0.00 & $80 \%$ & 1.50 \\
\hline Filter Min & Off & $85 \%$ & 1.20 & Filter Min & Off & $85 \%$ & 1.51 \\
\hline Filter Max & Off & $90 \%$ & 1.22 & Filter Max & Off & $90 \%$ & 1.52 \\
\hline \#Filtered & 0.00 & $95 \%$ & 1.23 & \#Filtered & 0.00 & $95 \%$ & 1.54 \\
\hline $\begin{array}{l}\text { Vanilla regular } \\
\text { ice cream }\end{array}$ & Value (-) & Percentile & Value (-) & $\begin{array}{l}\text { Chocolate regular } \\
\text { ice cream }\end{array}$ & Value (-) & Percentile & Value (-) \\
\hline Minimum & 0.88 & $5 \%$ & 0.96 & Minimum & 0.95 & $5 \%$ & 1.03 \\
\hline Maximum & 1.18 & $10 \%$ & 0.98 & Maximum & 1.24 & $10 \%$ & 1.04 \\
\hline Mean & 1.03 & $15 \%$ & 0.99 & Mean & 1.10 & $15 \%$ & 1.05 \\
\hline Std Dev & 0.04 & $20 \%$ & 0.99 & Std Dev & 0.04 & $20 \%$ & 1.06 \\
\hline Variance & 0.00 & $25 \%$ & 1.00 & Variance & 0.00 & $25 \%$ & 1.06 \\
\hline Skewness & -0.02 & $30 \%$ & 1.01 & Skewness & 0.02 & $30 \%$ & 1.07 \\
\hline Kurtosis & 2.62 & $35 \%$ & 1.01 & Kurtosis & 2.65 & $35 \%$ & 1.08 \\
\hline Median & 1.03 & $40 \%$ & 1.02 & Median & 1.09 & $40 \%$ & 1.08 \\
\hline Mode & 1.04 & $45 \%$ & 1.03 & Mode & 1.10 & $45 \%$ & 1.09 \\
\hline Left $X$ & 0.96 & $50 \%$ & 1.03 & Left $X$ & 1.03 & $50 \%$ & 1.09 \\
\hline Left $P$ & 0.03 & $55 \%$ & 1.04 & Left $P$ & 0.03 & $55 \%$ & 1.10 \\
\hline
\end{tabular}


Table S5: continued

\begin{tabular}{|c|c|c|c|c|c|c|c|}
\hline $\begin{array}{l}\text { Vanilla regular } \\
\text { ice cream }\end{array}$ & Value (-) & Percentile & Value (-) & $\begin{array}{l}\text { Chocolate regular } \\
\text { ice cream }\end{array}$ & Value (-) & Percentile & Value (-) \\
\hline Right X & 1.10 & $60 \%$ & 1.04 & Right X & 1.16 & $60 \%$ & 1.11 \\
\hline Right $\mathrm{P}$ & 0.98 & $65 \%$ & 1.05 & Right $\mathrm{P}$ & 0.98 & $65 \%$ & 1.11 \\
\hline Diff $X$ & 0.14 & $70 \%$ & 1.06 & Diff $X$ & 0.14 & $70 \%$ & 1.12 \\
\hline Diff $P$ & 0.95 & $75 \%$ & 1.06 & Diff $P$ & 0.95 & $75 \%$ & 1.12 \\
\hline \#Errors & 0.00 & $80 \%$ & 1.07 & \#Errors & 0.00 & $80 \%$ & 1.13 \\
\hline Filter Min & Off & $85 \%$ & 1.08 & Filter Min & Off & $85 \%$ & 1.14 \\
\hline Filter Max & Off & $90 \%$ & 1.09 & Filter Max & Off & $90 \%$ & 1.15 \\
\hline \#Filtered & 0.00 & $95 \%$ & 1.10 & \#Filtered & 0.00 & $95 \%$ & 1.20 \\
\hline
\end{tabular}

\begin{tabular}{|c|c|c|c|c|c|c|c|}
\hline $\begin{array}{l}\text { Vanilla } \\
\text { premium ice } \\
\text { cream }\end{array}$ & Value (-) & Percentile & Value (-) & $\begin{array}{l}\text { Chocolate } \\
\text { premium ice } \\
\text { cream }\end{array}$ & Value (-) & Percentile & Value (-) \\
\hline Minimum & 1.05 & $5 \%$ & 1.14 & Minimum & 1.15 & $5 \%$ & 1.23 \\
\hline Maximum & 1.39 & $10 \%$ & 1.16 & Maximum & 1.49 & $10 \%$ & 1.25 \\
\hline Mean & 1.21 & $15 \%$ & 1.17 & Mean & 1.30 & $15 \%$ & 1.26 \\
\hline Std Dev & 0.05 & $20 \%$ & 1.18 & Std Dev & 0.05 & $20 \%$ & 1.27 \\
\hline Variance & 0.00 & $25 \%$ & 1.19 & Variance & 0.00 & $25 \%$ & 1.28 \\
\hline Skewness & -0.01 & $30 \%$ & 1.19 & Skewness & 0.00 & $30 \%$ & 1.28 \\
\hline Kurtosis & 2.70 & $35 \%$ & 1.20 & Kurtosis & 2.74 & $35 \%$ & 1.29 \\
\hline Median & 1.22 & $40 \%$ & 1.21 & Median & 1.31 & $40 \%$ & 1.30 \\
\hline Mode & 1.21 & $45 \%$ & 1.21 & Mode & 1.30 & $45 \%$ & 1.30 \\
\hline Left $X$ & 1.14 & $50 \%$ & 1.22 & Left $X$ & 1.23 & $50 \%$ & 1.31 \\
\hline Left $P$ & 0.03 & $55 \%$ & 1.23 & Left $P$ & 0.03 & $55 \%$ & 1.32 \\
\hline Right X & 1.30 & $60 \%$ & 1.23 & Right X & 1.39 & $60 \%$ & 1.32 \\
\hline Right $P$ & 0.98 & $65 \%$ & 1.24 & Right $P$ & 0.98 & $65 \%$ & 1.33 \\
\hline Diff $X$ & 0.15 & $70 \%$ & 1.25 & Diff X & 0.16 & $70 \%$ & 1.33 \\
\hline Diff $P$ & 0.90 & $75 \%$ & 1.25 & Diff P & 0.95 & $75 \%$ & 1.34 \\
\hline \#Errors & 0.00 & $80 \%$ & 1.26 & \#Errors & 0.00 & $80 \%$ & 1.35 \\
\hline Filter Min & Off & $85 \%$ & 1.27 & Filter Min & Off & $85 \%$ & 1.36 \\
\hline Filter Max & Off & $90 \%$ & 1.28 & Filter Max & Off & $90 \%$ & 1.37 \\
\hline \#Filtered & 0.00 & $95 \%$ & 1.30 & \#Filtered & 0.00 & $95 \%$ & 1.39 \\
\hline
\end{tabular}


Table S6 Annual life cycle costs and value added at the sectoral level

\begin{tabular}{|c|c|c|c|c|c|c|c|c|}
\hline Products & $\begin{array}{r}\text { Sales value } \\
(£ \mathrm{~m})\end{array}$ & $\begin{array}{r}\text { Retail price } \\
(£)\end{array}$ & $\begin{array}{r}\text { Yearly } \\
\text { sales } \\
\text { volumes (t) }\end{array}$ & $\begin{array}{r}\text { Product } \\
\text { shares to } \\
\text { sub- } \\
\text { sectors }\end{array}$ & $\begin{array}{r}\text { Life cycle costs } \\
(£ / \mathbf{k g})\end{array}$ & $\begin{array}{r}\text { Savings } \\
(£ / k g)\end{array}$ & $\begin{array}{r}\text { Costs to } \\
\text { retailer }(\xi / \mathbf{k g})\end{array}$ & $\begin{array}{r}\text { Value } \\
\text { added } \\
(\mathfrak{\xi} / \mathbf{k g})\end{array}$ \\
\hline Crackers & 362 & 1.3 & 278,462 & $16.2 \%$ & 0.908 & 0.006 & 0.857 & 0.443 \\
\hline Low fat biscuits & 612 & 1.5 & 408,000 & $23.8 \%$ & 0.808 & 0.010 & 0.774 & 0.726 \\
\hline Semi-sweet biscuits & 281.5 & 1.1 & 255,909 & $14.9 \%$ & 0.787 & 0.006 & 0.749 & 0.351 \\
\hline Chocolate-coated biscuits & 208.5 & 2 & 104,250 & $6.1 \%$ & 0.879 & 0.007 & 0.851 & 1.149 \\
\hline Chocolate cream biscuits & 208.5 & 6.5 & 32,077 & $1.9 \%$ & 0.783 & 0.005 & 0.752 & 5.748 \\
\hline Vanilla cream biscuits & 281.5 & 6.4 & 43,984 & $2.6 \%$ & 0.717 & 0.004 & 0.685 & 5.715 \\
\hline Other biscuits confectionary & 654 & 1.1 & 594,545 & $34.6 \%$ & 0.908 & 0.004 & 0.857 & 0.243 \\
\hline Whole cakes & 287 & 6.8 & 42,206 & $11.7 \%$ & 2.640 & 0.009 & 2.556 & 4.244 \\
\hline Slices/bars & 362.3 & 8 & 45,288 & $12.6 \%$ & 2.128 & 0.020 & 2.019 & 5.981 \\
\hline Pies & 362.3 & 2 & 181,150 & $50.4 \%$ & 1.517 & 0.022 & 1.448 & 0.552 \\
\hline Cupcakes & 362.3 & 13 & 27,869 & $7.7 \%$ & 1.828 & 0.058 & 1.720 & 11.280 \\
\hline Cheesecake & 272 & 4.3 & 63,256 & $17.6 \%$ & 1.756 & 0.013 & 1.666 & 2.634 \\
\hline Moulded chocolate & 845 & 7.5 & 112,667 & $17.7 \%$ & 1.414 & 0.010 & 1.391 & 6.109 \\
\hline Chocolate countlines & 1817 & 6 & 302,833 & $47.6 \%$ & 1.156 & 0.026 & 1.146 & 4.854 \\
\hline Chocolate in bags & 1304 & 8.3 & 157,108 & $24.7 \%$ & 1.458 & 0.042 & 1.455 & 6.845 \\
\hline Other chocolate confectionary & 378 & 6 & 63,000 & $9.9 \%$ & 1.458 & 0.01 & 1.455 & 4.545 \\
\hline Vanilla regular ice cream & 55 & 2 & 27,500 & $6.8 \%$ & 1.029 & 0.020 & 0.778 & 1.222 \\
\hline Chocolate regular ice cream & 55 & 2 & 27,500 & $6.8 \%$ & 1.099 & 0.022 & 0.842 & 1.158 \\
\hline Vanilla premium ice cream & 221.5 & 5 & 44,300 & $11.0 \%$ & 1.210 & 0.022 & 0.967 & 4.033 \\
\hline Chocolate premium ice cream & 221.5 & 5 & 44,300 & $11.0 \%$ & 1.301 & 0.022 & 1.056 & 3.944 \\
\hline Other ice cream products & 580 & 2.225 & 260,674 & $64.5 \%$ & 1.301 & 0.02 & 1.056 & 1.169 \\
\hline
\end{tabular}


Table S6 Continued.

\begin{tabular}{|c|c|c|c|}
\hline Products & $\begin{array}{r}\text { Annual life } \\
\text { cycle costs }(£ \mathrm{~m})\end{array}$ & $\begin{array}{r}\text { Annual life cycle } \\
\text { savings ( }(£ m)\end{array}$ & $\begin{array}{r}\text { Annual value } \\
\text { added ( } \mathrm{Em})\end{array}$ \\
\hline Crackers & 253 & 1.75 & 123 \\
\hline Low fat biscuits & 330 & 4.05 & 296 \\
\hline Semi-sweet biscuits & 201 & 1.56 & 90 \\
\hline Chocolate-coated biscuits & 92 & 0.76 & 120 \\
\hline Chocolate cream biscuits & 25 & 0.16 & 184 \\
\hline Vanilla cream biscuits & 31 & 0.18 & 251 \\
\hline Other biscuits confectionary & 540 & 2.38 & 144 \\
\hline Whole cakes & 111 & 0.40 & 179 \\
\hline Cakes slices & 96 & 0.92 & 271 \\
\hline Pies & 275 & 4.04 & 100 \\
\hline Cupcakes & 51 & 1.62 & 314 \\
\hline Cheesecake & 111 & 0.84 & 167 \\
\hline Moulded chocolate & 159 & 1.15 & 688 \\
\hline Chocolate countlines & 350 & 7.88 & 1470 \\
\hline Chocolate in bags & 229 & 6.54 & 1075 \\
\hline Other chocolate confectionary & 92 & 0.63 & 286 \\
\hline Vanilla regular ice cream & 28 & 0.54 & 34 \\
\hline Chocolate regular ice cream & 30 & 0.59 & 32 \\
\hline Vanilla premium ice cream & 54 & 0.95 & 179 \\
\hline Chocolate premium ice cream & 58 & 0.95 & 175 \\
\hline Other ice cream products & 339 & 5.21 & 305 \\
\hline
\end{tabular}

